\title{
New Residential Construction Compliance: Evaluation of the Washington State Energy Code Program
}

W. M. Warwick
A. D. Lee
L. J. Sandahl
D. L. Durfee
E. E. Richman

July 1993

Prepared for Pam Brandis, RPEB the Bonneville Power Administration under a Related Services Agreement with the U.S. Department of Energy Contract DE-AC06-76RLO 1830

Pacific Northwest Laboratory Richland, Washington 99352 


\title{
DISCLAIMER
}

This report was prepared as an account of work sponsored by an agency of the United States Government. Neither the United States Government nor any agency thereof, nor Battelle Memorial Institute, nor any of their employees, makes any warranty, expressed or implied, or assumes any legal liability or responsibility for the accuracy, completeness, or usefulness of any information, apparatus, product, or process disclosed, or represents that its use would not infringe privately owned rights. Reference herein to any specific commercial product, process, or service by trade name, trademark, manufacturer, or otherwise does not necessarily constitute or imply its endorsement, recommendation, or favoring by the United States Government or any agency thereof, or Battelle Memorial Institute. The views and opinions of authors expressed herein do not necessarily state or reflect those of the United States Covernment or any agency thereof.

\author{
PACIFIC NORTHWEST LABORATORY \\ operated by \\ BATTELLE MEMORIAL INSTITUTE \\ for the \\ UNITED STATES DEPARTMENT OF ENERGY \\ under Contract DE-ACO6-76RLO 1830
}

Printed in the United States of America

\begin{abstract}
Available to DOE and DOE contractors from the
Office of Scientific and Technical Information, P.O. Box 62, Oak Ridge, TN 37831; prices available from (615) 576-8401. FTS 626-8401.
\end{abstract}

Available to the public from the National Technical Information Service, U.S. Department of Commerce, 5285 Port Royal Rd., Springfield, VA 22161. 
NEW RESIDENTIAL CONSTRUCTION COMPLIANCE:

EVALUATION OF THE WASHINGTON STATE

ENERGY CODE PROGRAM
W. M. Warwick
A. D. Lee
L. J. Sandal
D. L. Durfee
E. E. Richman

July 1993

Prepared for Pam Brandis, RPEB the Bonneville Power Administration under a Related Services Agreement with the U.S. Department of Energy

Contract DE-ACO6-76RLO 1830

Pacific Northwest Laboratory

Richland, Washington 


\title{
DISCLAIMER
}

This report was prepared as an account of work sponsored by an agency of the United States Government. Neither the United States Government nor eny agency thereof, nor Battelle Memorial Institute, nor any of their employees, makes any warranty, expressed or implied, or assumes any legal liability or responsibility for the accuracy, completeness, or usefulness of any information, apparatus, product, or process disclosed, or represents that its use would not infringe privately owned rights. Reference herein to any specific commercial product, process, or service by trade name, trademark, manufacturer, or otherwise does not necessarily constitute or imply its endorsement, recommendation, or favoring by the United States Government or any agency thereof, or Battelle Memorial Institute. The views and opinions of authors expressed herein do not necesserily state or reflect those of the United States Government or any agency thereof.

\author{
PACIFIC NORTHWEST LABORATORY \\ operated by \\ BATTELLE MEMORIAL INSTITUTE \\ for the \\ UNITED STATES DEPARTMENT OF ENERGY \\ under Contract DE-AC06-76RLO 1830
}

Printed in the United States of America

Available to DOE and DOE contractors from the

Office of Scientific and Technical Information, P.O. Box 62, Oak Ridge, TN 37831: prices available from (615) 576-8401. FTS 626-8401.

Available to the public from the National Technical Information Service. U.S. Department of Commerce, 5285 Port Royal Rd., Springfield, VA 22161. 


\section{SUMMARY}

In 1990, the Washington State Legislature passed a residential energy efficiency code to be effective July 1, 1992. The Bonneville Power Administration (Bonneville) supported passage and implementation of the code to ensure that new electrically heated residences in the State of Washington were as energy efficient as possible. Bonneville contracted with the Washington State Energy Office (WSEO) to provide code implementation support to the building industry and code enforcement jurisdictions through the Washington State Energy Code (WSEC) program. Support under the WSEC program includes training and other activities to provide builders and building inspectors with knowledge of the energy efficiency features of the code to ensure high levels of code compliance.

The WSEC program was initiated in 1992, prior to the effective date of the WSEC. The first phase of the program, consisting primarily of start-up efforts and early training sessions, was the subject of a previous process evaluation by the Pacific Northwest Laboratory (PNL). That evaluation found that systems were in place to accomplish the training and other support planned under the WSEC program. However, few buildings had been constructed to the WSEC at that time and there was no basis for drawing conclusions about the success of the WSEC program in achieving code compliance. Those conclusions are the subject of this report.

The objective of this evaluation of the WSEC program was to assess the components of the program and determine the effectiveness of the WSEC program in terms of code compliance. Although implementation of the WSEC by local jurisdictions is mandatory, participation in the WSEC program is voluntary. This potentially provided a basis for assessing the effectiveness of the program by comparing results between jurisdictions that participated in the WSEC program and those that did not. Unfortunately, the code compliance scope of this evaluation was largely limited to WSEC program participants due to monitoring protocols established by Bonneville, WSEO, and local jurisdictions. Nevertheless, interviews were conducted with a sample of code officials in non-participating jurisdictions. The interviews revealed that even code officials in jurisdictions not participating in the program typically took 
part in training and technical assistance offered through the program, reducing their potential as a "control" group for comparison purposes.

Code compliance is difficult to measure and is rarely the subject of evaluation. This evaluation employed methods that relied on field data collected by WSEO to assess compliance. The WSEO data were drawn from a "construction checklist" used by WSEO to identify areas of code implementation that may require specific support in the training they provide. Using the checklist, data were collected for major construction activities and graded on a four-point scale, which gave a relative measure of the completeness of compliance. Compliance was measured at the time of inspection, not at completion. Final levels of compliance were not checked. Therefore conclusions drawn in this report may underrate final levels of compliance.

Simple tabulations of this data are useful for identification of areas of code non-compliance, but they fail to provide a solid basis for assessing energy savings impacts. As a result, PNL developed a method that translated these categorical measures of compliance into measures of heat transfer that could be used in a standard engineering model of heat loss. This model was developed to represent three common home designs and sizes. The WSEO data were translated into indices that reflected the fraction of savings achieved for each construction element in terms of whole house heat loss.

Evaluation results indicate there is some non-compliance with the code; however, this is estimated to have little impact on the thermal performance of typical homes. Near complete achievement of the energy savings objectives of the WSEC was projected based on homes inspected in the first full year after implementation of the code. The role of the WSEC program in achieving this result is unclear. The WSEC was not the first energy efficiency code in Washington; nor did it require a significantly different way of home building. Concurrent with WSEC development, Bonneville was promoting similar energy efficiency standards through voluntary adoption of enhanced codes by local jurisdictions and through building standards administered by utilities. The non-WSEC energy efficiency standards included training programs similar to the WSEC program. As a result, differences in code compliance between jurisdictions that participated in the WSEC program and those that did not, or those where construction levels were low, were not significant. 
The results of this evaluation need to be $\mathrm{placed}$ in a broader context before making inferences to other areas. First, energy-efficient building codes have been aggressively promoted in the Pacific Northwest region since 1983. Washington State was the focus of much of this activity. As a result, the institutional environment for both code adoption and compliance was established prior to code adoption. Second, despite the high projected rate of compliance, improvements in the code and the training are needed. Specific comments indicate a need to simplify compliance under the two most popular compliance "paths" and changes to the code need to be synchronized with the revision cycles of national building codes, so that training can encompass both. Third, the WSEC program included training for builders, but builders were not aggressively recruited by WSEO and their participation in training was low. Further, participation in training by subcontractors who actually do much of the construction was non-existent. As a result, building inspectors thought they were spending too much time teaching builders about the code during site inspections. Finally, code compliance is heavily dependent on a sense that energy efficiency is valued: by consumers so builders will build to meet the market; by constituents so jurisdictions will adopt and support enforcement; and by jurisdictions so inspectors will enforce the code.

The major conclusions from this evaluation are:

- Training should be continued to ensure high levels of compliance. (It is not clear from this evaluation if the WSEC program is the "best" vehicle for this training.)

- Participation of builders and sub-contractors in training needs to be increased; a certification process might increase participation.

- The WSEC needs to be revised to simplify implementation and to adapt it to building code revision cycles.

- Bonneville should review the role of energy efficiency codes as resource acquisition mechanisms and adopt a clear policy regarding this role.

- Energy efficiency should continue to be promoted to ensure market demand for energy-efficient homes and high levels of code compliance.

- Code compliance can be evaluated and savings projected using quantitative measures. 


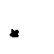




\section{ACKNOWLEDGMENTS}

We would like to thank Pam Brandis and Doug Couch of the Bonneville Power Administration, Mike McCourt formerly of the Association of Washington Cities, and Vince Schueler of the Washington State Energy Office, for their guidance and support in the development of this evaluation effort. We would also like to acknowledge Terri Gilbride of the Pacific Northwest Laboratory for her editorial assistance. 


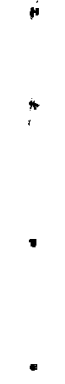


CONTENTS

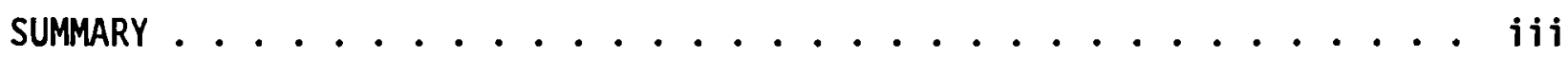
ACKNOWLEDGMENTS ................................. vii 1.0 InTRODUCTION . . . . . . . . . . . . . . . . . . . 1.1

1.1 OBJECTIVES . . . . . . . . . . . . 1.1

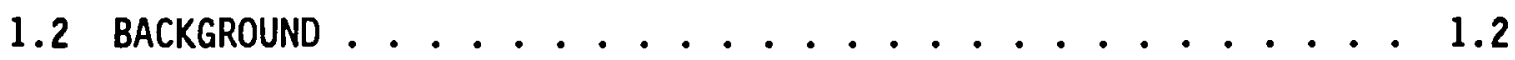

1.2.1 The Energy and Ventilation Codes . . . . . . 1.2

1.2.2 The Washington State Energy Code Program . . . . . 1.3

1.3 ORGANIZATION OF THE REPORT . . . . . . . . . . 1.6

2.0 BUILDING STOCK CHARACTERISTICS . . . . . . . . . 2.1

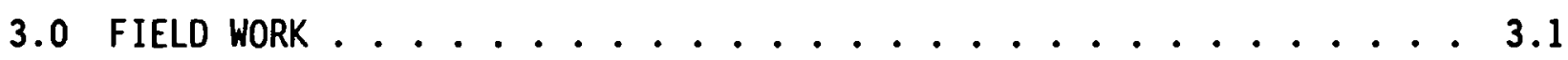

3.1 APPROACH: WSEO's MONITORING PLAN ............... 3.1

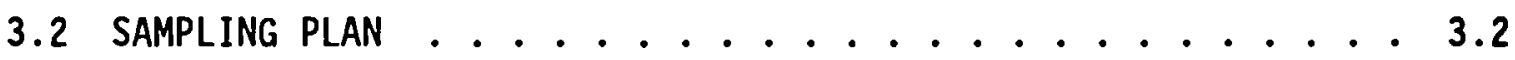

3.2.1 Sample Size and Distribution ............ 3.2

3.2.2 PNL Review of WSEO Sampling Plan ........ 3.3

3.3 WSEO SITE INSPECTION PROCEDURES . . . . . . . . . 3.3

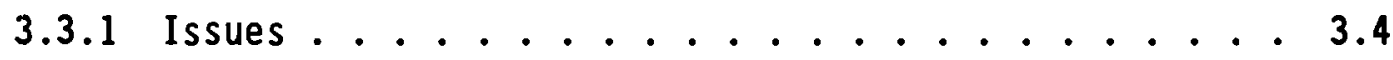

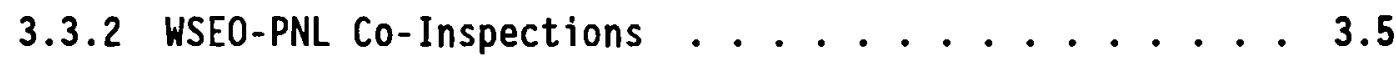

3.4 PNL INDEPENDENT SITE INSPECTIONS . . . . . . . . 3.7

3.5 ANALYSIS OF SITE INSPECTION DATA . . . . . . . 3.8

4.0 WSEO SITE INSPECTION DATA ANALYSIS . . . . . . . . . . 4.1

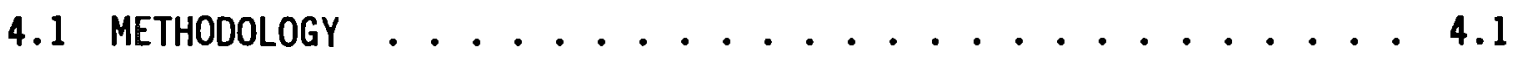

4.1.1 Benchmark .............. 4.3

4.1.2 Component UA Calculation Method ........ 4.4 
4.2 WSEO SITE INSPECTION DATA ANALYSIS RESULTS . . . . . . 4.5

4.2.1 Building Component Results ........... 4.5

4.2.2 Thermal Performance Simulation Results ...... 4.11

4.3 PNL SITE INSPECTION DATA ANALYSIS RESULTS . . . . . . 4.12

4.3.1 Building Component Results .......... 4.12

4.3.2 Thermal Performance Simulation Results . . . . 4.14

5.0 WASHINGTON STATE ENERGY CODE PROGRAM PROCESS EVALUATION $\ldots \ldots .$.

5.1 INTRODUCTION AND BACKGROUND ............. 5.1

5.1.1 Program Purpose .............. 5.1

5.1 .2 Prior Studies . . . . . . . . . . . . 5.2

5.2 OVERVIEW AND PURPOSE OF PROCESS EVALUATION ...... 5.4

5.3 EVALUATION METHODOLOGY .................... 5.5

5.3.1 Sample Selection ............. 5.5

5.3.2 Data Collection............ 5.9

5.3.3 Data Analysis........... 5. . 5

5.4 KEY PROCESS EVALUATION FINDINGS . . . . . . . . 5.11

5.4.1 Influence of External Factors ......... 5.12

5.4.2 Effectiveness of Program Components ....... 5.16

5.4 .3 Overall Program Success . . . . . . . . . 5.20

5.4 .4 other Issues . . . . . . . . . . 5.23

6.0 CONCLUSIONS AND RECOMMENDATIONS . . . . . . . . . . 6.1

6.1 THE ROLE OF THE WSECP IN COMPLIANCE WITH THE WSEC . . . . . 6.1

6.1 .1 Main Conclusions ............ 6.2

6.1 .2 Themes ................. 6.3

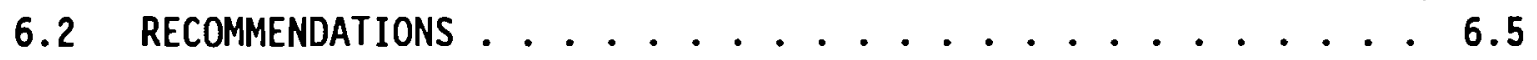

6.2.1 Continue Support of the WSEC to Maintain High Levels of Compliance ................. 6.6 
6.2.2 Review the WSEC for Revisions to Address Problems Noted ............... 6.8

6.2.3 Develop a Position On, or Strategy For, Energy Codes and Standards as Resource Acquisition Mechanisms . . 6.9

6.2.4 Develop a "Marketing" Strategy and Appropriate Materials to Reinforce the Value of Energy Code Compliance ................. 6.10

6.2.5 Enhance Participation in Code Implementation and Enforcement "Networks" ........... 6.11 7.0 REFERENCES . . . . . . . . . . . . . 7.1 APPENDIX A - WSEO MONITORING PLAN . . . . . . . . . . A.1 APPENDIX B - WSEO CONSTRUCTION SITE CHECKLIST . . . . . . . . B.1 APPENDIX C - PNL RECOMMENDATIONS TO WSEO . . . . . . . . . C.I APPENDIX D - RICHMAN LETTER . . . . . . . . . . . . D.1 APPENDIX E - CONSTRUCTION SITE CHECKLIST DATA ANALYSIS BUILDING PROTOTYPES E.I APPENDIX F - BUILDING COMPONENT UA CALCULATION METHOD . . . . . . F.1 APPENDIX G - DETAILED INFORMATION ON PARTICIPATING JURISDICTIONS. . . . G.1 APPENDIX H - PROCESS SURVEY QUESTIONNAIRES . . . . . . . . H.l APPENDIX I - DETAILED FINDINGS OF THE PROCESS EVALUATION . . . . . I.1 


\section{FIGURES}

2.1 WSECP Building Activity - Cumulative Single-Family by Quarter . . . 2.5

2.2 WSECP Building Activity - Cumulative Single-Family by Month . . . 2.7

4.1 Average Compliance Rating from 128 WSEO Site Inspections . . . . . 4.7

4.2 Average Compliance Rating by Code History . . . . . . . . . . . 4.8

4.3 Average Compliance Rating by Building Activity Level . . . . . . . 4.10

5.1 Categories of Code Jurisdictions . . . . . . . . . . . 5.12

\section{$\underline{\text { TABLES }}$}

2.1 High Construction Jurisdictions . . . . . . . . . . . . 2.2

2.2 Moderate Construction Jurisdictions . . . . . . . . . . 2.3

2.3 Low Construction Jurisdictions . . . . . . . . . . . 2.3

2.4 Permits and Completes by Quarter for WSECP Participants . . . . . 2.4

2.5 Permits and Completes by Month for WSECP Participants . . . . . . 2.6

3.1 WSEO 1992-93 Construction Season Site Inspection Sample . . . . 3.2

3.2 Construction Site Inspections to Date (3-93) . . . . . . . . 3.3

4.1 Code Compliance Rating Insulation Levels . . . . . . . . . . . 4.2

4.2 Data Analysis Benchmark Thermal Characteristics . . . . . . . . 4.4

4.3 Prototype Total UA Values by Compliance Level and Climate Zone . . . 4.5

4.4 Average Component Compliance Rating . . . . . . . . . . . . . . 4.6

4.5 Average Component Compliance Rating Categorized
by Energy Code History . . . . . . . . . . . . . . . . 4 4.8

4.6 Average Component Compliance Rating Categorized by

4.7 Average Component Compliance Rating Categorized

by Geographic Location ................. . . 4.10 
4.8 Average Percent Code Compliance Based on Prototype

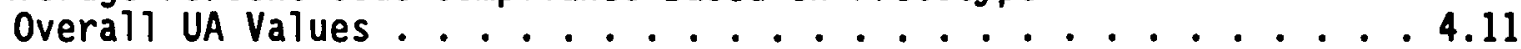

4.9 Average Component Compliance Rating for Sites Inspected by PNL . . . 4.13

4.10 Average Component Compliance Rating Categorized by Energy Code History for Sites Inspected by PNL . . . . . . . . . . . 4.13

4.11 Average Component Compliance Rating Categorized by Building Activity for Sites Inspected by PNL . . . . . . . . 4 4.14

4.12 Average Percent Code Compliance Based on Prototype Overall UA Values for Sites Inspected by PNL . . . . . . . . 4.15

5.1 WSECP Participant and Non-Participant Jurisdiction Sample Frame Groups ........................ 5.6

5.2 Distribution of Jurisdictions by Bonneville Area Office and Study Group, Number in Group, and Number Interviewed . . . . . . . 5.8 


\subsection{INTRODUCTION}

This report describes the Pacific Northwest Laboratory's (PNL's) evaluation of the Washington State Energy Code Program (WSECP).

In 1990, the Washington State Legislature passed a residential energy efficiency code to be effective July 1, 1992. Bonneville supported passage and implementation of the code to ensure that new residences in the State of Washington were as energy efficient as economically feasible. The Washington State Energy Office (WSEO) is conducting the WSECP for Bonneville to support code implementation. This support takes several forms, including providing training to code enforcement officials, technical support both in the field and through telephone "hot lines," and computerized tools to review house plans for code compliance.

WSEO began implementing the WSECP in 1992, prior to the effective date of the new code. This first phase of the WSECP was the subject of an earlier process evaluation conducted by PNL. From that evaluation PNL found that most new homes being built immediately after the code went into effect were "grandfathered" under the old code. The training program for the new code was in place and sessions were being attended by the jurisdictions but it was too early to determine if the training was effective in improving code compliance and easing the transition to the new energy code. That is the subject of this evaluation.

\subsection{OBJECTIVES}

The objective of this evaluation was to determine the effectiveness of the WSECP in helping builders and jurisdictions switch to the new WSEC and the level of compliance with the new code as a measure of program effectiveness. This objective was achieved through three related activities. The first activity was to collect data on the history of energy code and standards experience and current construction activity in each jurisdiction. The second activity was to conduct on-site inspections of a sample of homes built under the WSEC. The third major activity in this evaluation was to conduct interviews with key individuals responsible for implementation, administration, or oversight of the WSECP or the WSEC. 


\subsection{BACKGROUND}

In January 1990, the Washington State Legislature passed a measure that ordered the creation of new statewide building codes. This legislation (ESHB 2198) directed the Washington State Building Code Council (WSBCC) to develop energy efficiency standards for all new residential and commercial buildings permitted after July 1, 1991, as well as ventilation requirements for some new buildings. These new codes would be modeled after the Model Conservation Standards (MCS) originally proposed by the Northwest Power Planning Council in its $1983 \mathrm{plan}$ (NWPPC). In response to the legislation, the WSBCC developed the Washington State Energy Code (energy code) (WSBCC 1991) and its companion, the Ventilation and Indoor Air Quality Code (ventilation code).

The WSEC is the first state-wide MCS-equivalent code in Washington. However, previous codes and building standards programs were in $\mathrm{place}$ in some jurisdictions. These include the Super Good Cents (SGC) program, the Northwest Energy Code (NWEC), the MCS implemented through Bonneville's Early Adopter Program, and state-wide energy codes passed in 1981 and 1986. All of these codes or programs are based on the NWPPC's MCS, but each was implemented differently. The MCS was developed primarily using computer models and engineering estimates of residential energy efficiency measure performance. The actual performance of these measures and of the MCS was demonstrated through Bonneville's Early Adopter and Residential Standards Demonstration Programs (RSDP). Results from these programs led to revisions in the MCS and the development of the NWEC and standards for the SGC new home efficiency marketing program.

\subsubsection{The Energy and Ventilation Codes}

The energy code specifies construction standards that are different for individual climate zones and classes of fuels used for space heating. The code is relatively complex in that it can be implemented in one of three ways. The "prescriptive path" specifies design and material characteristics. The "component performance" approach allows more design flexibility where predicted performance can be verified by calculating the heat loss using standard software. The WSECP participants received copies of the WATTSUN heat 
loss software to use. The "system analysis" path allows the builder to demonstrate compliance by accounting for both heat loss and gain.

The ventilation code sets design and component standards for radon mitigation for new construction in six counties deemed to be high risk areas. This code is applied without regard to the path taken to meet the thermal code.

The energy code sets both minimum and maximum standards for energy efficiency. With the exception of those jurisdictions that already have energy codes in excess of the new state-wide code, all jurisdictions must enforce the new codes as written. The codes are specified for two climate zones (which are east and west of the Cascade Mountain Range). They are further specified by two types of space heating fuel: electric resistance heat and "all other" fuels.

In addition to mandating thermal and ventilation requirements, the legislation provides for financial incentives to owners (at the time of construction) of certain electrically heated dwellings. The electric utility serving the load is required to pay $\$ 900$ for each new single-family home of less than 2,000 square feet and $\$ 390$ for each multifamily unit that complies with the new code. These incentive payments will be paid for all homes constructed between July 1, 1991, and July 1, 1995. Other funds for training code officials and code enforcement are to be provided by gas and electric utilities through contributions to a fund for local governments.

\subsubsection{The Washington State Energy Code Program}

The WSECP is intended to facilitate implementation of this new code through development of "a favorable environment that assures sound energyefficient construction practices which meet the WSEC" (WSEO 1991). The program is operated by the WSEO under contract to Bonneville.

Participation in the WSECP is voluntary, although it is encouraged through direct incentives including participation payments. Program activities are primarily directed toward providing education and training, technical assistance, and financial support for implementation of the energy 
and ventilation codes. Last year's penetration rate for electrically heated single-family-home starts in the WSECP was about $65 \%$.

\section{Training}

The WSECP provides training primarily to code officials, as well as to builders, and building materials suppliers. Code officials receive training on the code, different compliance paths, the WATTSUN heat loss software, and program participation matters. Builders learn about approved construction techniques and thermal standards. Suppliers learn about the code and its implications for materials supplied to their customers. WSEO's builder and supplier training was very limited and designed to supplement other training efforts.

The WSEO Energy Extension Service (EES) operates the training phase of the code program. The goal of the EES is "to provide in a timely manner accurate technical information ... to all building jurisdictions in the state." (a)

The technical assistance focuses on providing workshops, seminars, and written support material to builders, subcontractors, suppliers, and code officials. Information is also available to the general public.

Five individual workshops designed for code officials are offered on a rotating basis throughout the state. These cover plan review, compliance and heat loss calculations, field inspections, indoor air quality and mechanical ventilation requirements, and an overview of the code. Upon request, EES personnel travel to individual jurisdictions to offer personalized, hands-on training.

Supplier training targets those selling windows, general construction materials, insulation, and ventilation equipment. Builder training is coordinated with local enforcement jurisdictions and often is co-sponsored by local organizations, such as contractor associations.

To supplement the training a variety of written material is available. A code checklist produced by EES guides code officials and builders in the

(a) Washington State Energy Office. 1991. Draft Washington State Energy Code Training Plan, FY 1992, Olympia, Washington. 
Requirements" al so produced by EES, provide code highlights and refer readers to the Washington State Association of Building Officials for copies of the complete text of the code.

\section{Technical Assistance}

Technical assistance is provided to anyone requesting it. The WSEO has established a toll-free "hotline" to field questions about the code and the code program. Four roving technical advisors (who double as hotline staff during busy times) are available to local jurisdictions and others for consultation on code-related questions. Other field personnel provide information about the code program itself. These people provide training and answer questions about program participation, compliance, and reporting requirements.

\section{Financial Assistance}

Although WSEO provides technical assistance and training to anyone within Washington state, jurisdictions participating in the WSECP are eligible to receive specific financial benefits. These benefits are designed to defray the costs of startup, implementation, and enforcement of the new codes.

Program participants that were not enforcing the NWEC on July 1, 1991, receive an initial grant of $\$ 4,000$ to pay costs associated with enforcement of the WSEC. These grants may be used for computers, equipment and supplies, and printing and development of training materials. In addition, each code enforcement person attending at least one training session qualifies for a $\$ 600$ training allowance. As code enforcement activities continue, jurisdictions are eligible for technical assistance payments based on the number of building permits and energy inspections completed for electrically heated homes. Program participants that were enforcing the NWEC on July 1, 1991, are eligible for training and technical assistance support, but receive no startup payments.

In return, participating jurisdictions agree to provide technical assistance to builders, coordinate with utilities to facilitate the required incentive payments, and provide documentation to the WSEO on program-related activities. 
All of these activities - the training, technical, and financial assistance - are intended to facilitate implementation of the code.

\section{Monitoring}

WSEO developed a Monitoring Plan to track implementation of the WSEC. WSEO's monitoring program includes on-site inspections using a construction practices checklist. Their data collection methods were extensively reviewed and approved by code enforcement officials and other organizations interested in building code compliance. Rather than duplicate this work and subject jurisdictions and builders to possibly redundant house inspections, PNL arranged to utilize WSEO's data. To ensure that WSEO's methodology was satisfactory, PNL conducted a limited number of on-site inspections jointly with WSEO to validate their methodology; PNL also conducted additional inspections, without WSEO, to provide a benchmark to examine WSEO's data for potential bias (see chapters 3 and 4 of this report.)

\subsection{ORGANIZATION OF THE REPORT}

This report is organized to reflect the major activities implemented to conduct the evaluation, the analyses conducted with data collected by PNL and WSEO, and our conclusions. Chapter 1 states the objective of this research and provides background information describing the WSEC and the WSECP taken from the earlier process evaluation. Chapter 2 describes building stock characteristics of Washington State. Chapter 3 describes the approach used by WSEO and PNL in the field evaluations. Chapter 4 presents the findings of PNL's data analysis. Chapter 5 presents the methodology and findings of our process analysis. Chapter 6 provides conclusions and recommendations. Appen$\operatorname{dix}$ A contains a copy of the WSEO monitoring plan. Appendix B contains the WSEC monitoring checklist. Appendix $C$ and $D$ provide copies of letters to WSEO listing PNL's recommendations. Appendix E provides descriptions of construction site building prototypes. Appendix $F$ describes the building component UA calculation method. Appendix $G$ describes participating jurisdictions. Appendix I provides detailed findings of the process evaluation. 


\subsection{BUILDING STOCK CHARACTERISTICS}

Historic rates of construction provide several insights into future construction. First, they provide data upon which estimates of construction can be made, using statistical estimates or through regression or other trend models. Second, they provide information on the distribution of construction activity through both time and space. Construction activities are sensitive to seasonal factors. Residential construction occurs out of doors and certain seasons are easier to build in than others. In addition, the annual schedule of human activities, especially school, vacation, and gardening schedules, act to cluster relocation and home buying in the Spring and Summer months. This dictates an early Spring beginning for the peak construction period.

The market for housing is also a function of population. As a result, construction activity is greatest nearer existing population centers. This dictates that certain jurisdictions will have more construction activity than others. Housing construction is regulated by local jurisdictions. As a result, another indicator of potential housing construction activity is construction permits. WSEO used both historic rates and distributions of housing and recent construction permits to develop the sample for their monitoring plan. Initially, they decided to use jurisdictions as the sampling unit since building data is compiled at this level. They also decided to stratify the sample by level of building activity.

Three strata were identified. Historic records indicate that $80 \%$ of new construction occurs in less than $20 \%$ of the roughly 160 Washington jurisdictions. WSEO was advised to conduct site visits in each of the 25 "high" construction jurisdictions. These were characterized as jurisdictions with 50 or more electrically heated housing starts. Two additional strata were identified in the sampling $\mathrm{plan}$ : moderate and low construction activity. "Moderate" jurisdictions were defined as those with five or more electrically heated housing starts excluding the 25 "high" jurisdictions. Jurisdictions with fewer than five electrically heated housing starts were designated as "low" jurisdictions. The initial sampling plan called for visits to 15 moderate and 10 low construction jurisdictions. The final plan adopted in March 1992 revised this target to 10 "moderate" and 5 "low" jurisdictions. The 
jurisdictions with high, moderate, and low building activity are ranked by the total single-family permits issued in 1991 and listed in Tables 2.1, 2.2, and 2.3 respectively. Counties 1 isted in all capital letters on these tables are jurisdictions selected for WSEO site inspections; an asterisk indicates current participants in the WSECP.

TABLE 2.1. High Construction Jurisdictions

\begin{tabular}{|c|c|c|c|}
\hline \multicolumn{2}{|r|}{ Jurisdiction (a) } & County & $\begin{array}{l}\text { Geographic } \\
\text { Location }\end{array}$ \\
\hline $\begin{array}{l}1 . \\
2 . \\
3 . \\
4 . \\
5 . \\
6 . \\
7 . \\
8 . \\
9 . \\
10 . \\
11 . \\
12 . \\
13 . \\
14 . \\
15 . \\
16 . \\
17 . \\
18 . \\
19 . \\
20 . \\
21 . \\
22 . \\
23 . \\
24 . \\
25 .\end{array}$ & $\begin{array}{l}\text { King County } \\
\text { Pierce County } \\
\text { CLARK COUNTY * } \\
\text { KITSAP COUNTY * } \\
\text { SNOHOMISH COUNTY * } \\
\text { SPOKANE COUNTY * } \\
\text { THURSTON COUNTY * } \\
\text { ISLAND COUNTY * } \\
\text { Whatcom County } \\
\text { Spokane } \\
\text { SEATTLE * } \\
\text { MASON COUNTY * } \\
\text { Yakima County } \\
\text { Tacoma } \\
\text { Skagit County } \\
\text { JEFFERSON COUNTY * } \\
\text { CLALLAM COUNTY * } \\
\text { Lacey * } \\
\text { San Juan County * } \\
\text { Chelan County * } \\
\text { Everett } \\
\text { Kitt itas County * } \\
\text { ENUMCLAW * } \\
\text { Federal Way * } \\
\text { MOUNT VERNON * }\end{array}$ & $\begin{array}{l}\text { King } \\
\text { Pierce } \\
\text { Clark } \\
\text { Kitsap } \\
\text { Snohomish } \\
\text { Spokane } \\
\text { Thurston } \\
\text { Island } \\
\text { Whatcom } \\
\text { Spokane } \\
\text { King } \\
\text { Mason } \\
\text { Yakima } \\
\text { Pierce } \\
\text { Skagit } \\
\text { Jefferson } \\
\text { Clallam } \\
\text { Thurston } \\
\text { San Juan } \\
\text { Chelan } \\
\text { Snohomish } \\
\text { Kittitas } \\
\text { King } \\
\text { King } \\
\text { Skagit }\end{array}$ & $\begin{array}{l}\text { West } \\
\text { West } \\
\text { West } \\
\text { West } \\
\text { West } \\
\text { West } \\
\text { West } \\
\text { West } \\
\text { West } \\
\text { West } \\
\text { West } \\
\text { West } \\
\text { East } \\
\text { West } \\
\text { West } \\
\text { West } \\
\text { West } \\
\text { West } \\
\text { West } \\
\text { West } \\
\text { West } \\
\text { East } \\
\text { West } \\
\text { West } \\
\text { West }\end{array}$ \\
\hline $\begin{array}{l}\text { (a) } \\
\text { (b) }\end{array}$ & \multicolumn{3}{|c|}{$\begin{array}{l}\text { CAPS }=\text { WSEO site visit sample. }(*)=\text { WSECP participant. } \\
\text { East or west of the Cascade Mountain Range. }\end{array}$} \\
\hline
\end{tabular}


TABLE 2.2. Moderate Construction Jurisdictions

\begin{tabular}{|c|c|c|c|}
\hline & Jurisdiction (a) & County & $\begin{array}{l}\text { Geographic } \\
\text { Location }(b)\end{array}$ \\
\hline $\begin{array}{l}1 . \\
2 . \\
3 . \\
4 . \\
5 . \\
6 . \\
7 . \\
8 . \\
9 . \\
10 .\end{array}$ & $\begin{array}{l}\text { Klickitat County } * \\
\text { Pend Oreille County * } \\
\text { Steilacoom } \star \\
\text { Turmater } \star \\
\text { Brier } \\
\text { Mukilteo } \\
\text { Asot in County } \\
\text { DES MOINES } \\
\text { Mercer Island * } \\
\text { Poulsbo * }\end{array}$ & $\begin{array}{l}\text { Klickitat } \\
\text { Pend Oreille } \\
\text { Pierce } \\
\text { Thurston } \\
\text { Snohomish } \\
\text { Snohomish } \\
\text { Asotin } \\
\text { King } \\
\text { King } \\
\text { Kitsap }\end{array}$ & $\begin{array}{l}\text { East } \\
\text { East } \\
\text { West } \\
\text { West } \\
\text { West } \\
\text { West } \\
\text { East } \\
\text { West } \\
\text { West } \\
\text { West }\end{array}$ \\
\hline $\begin{array}{l}\text { (a) } \\
\text { (b) }\end{array}$ & \multicolumn{3}{|c|}{$\begin{array}{l}\text { CAPS }=\text { WSEO site visit sample. }\left({ }^{*}\right)=\text { WSECP participant. } \\
\text { East or west of the Cascade Mountain Range. }\end{array}$} \\
\hline
\end{tabular}

IABLE 2.3. Low Construction Jurisdictions

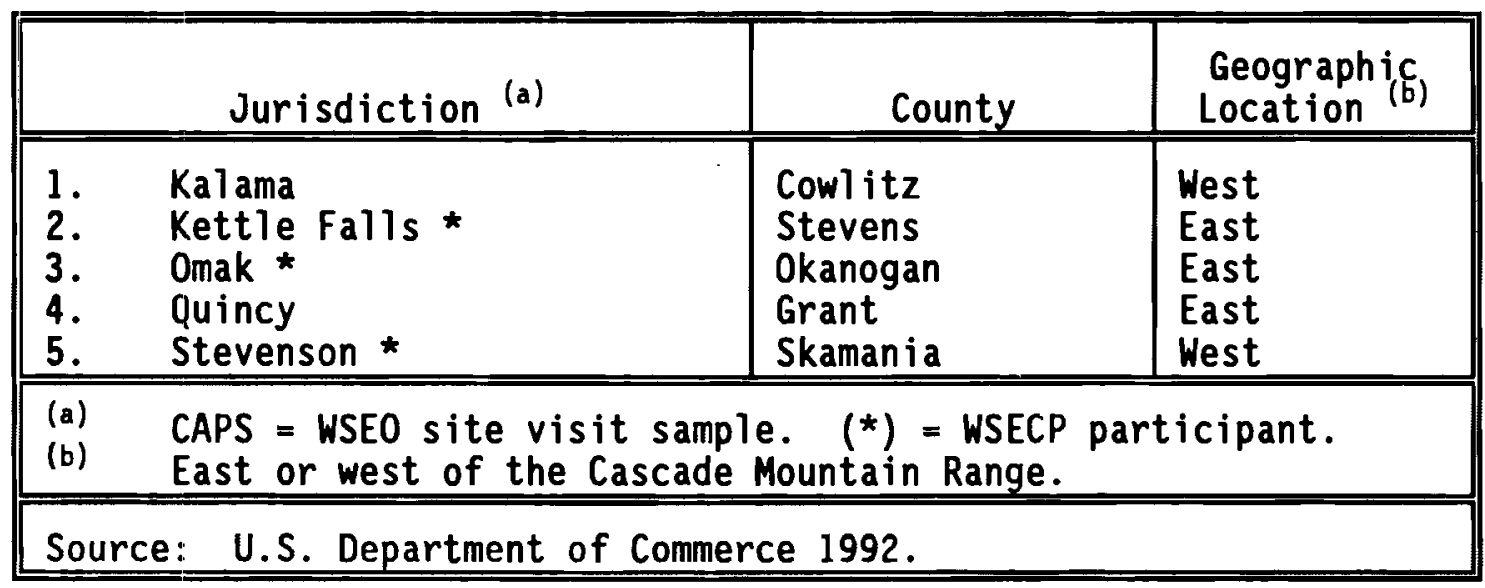

Permits are issued from the local jurisdictions and are valid for approximately six months. At the beginning of the WSEC, a transition period was allowed by issuing "grandfather" permits. Buildings with "grandfathered" permits did not have to meet the WSEC. Once the building permit is issued, construction can begin. Inspections occur at each stage of construction, these include a plan check, foundation, framing, insulation, and final inspection. The local code official inspects each construction stage for compliance 
with the state energy and building codes. When the building is completed, an occupancy permit is placed on the residence stating it is ready for occupancy.

Building permits are not a complete indication of a jurisdiction's building activity. Only a fraction of the permits issued actually get completed and there is a lag period between issued permits and completed construction. Table 2.4 lists single-family, electrically heated home permits and completes for jurisdictions participating in the WSECP. Figure $2.1 \mathrm{graph}$ ically displays the cumulative number of permits and completes reported by participating jurisdictions since the beginning of the program. At the end of the fifth quarter, September 1992, only $23 \%$ of the permits have been completed. After the third quarter in Figure 2.1, the permits and completes begin to diverge significantly. Table 2.5 lists the permits and completes for those jurisdictions reporting monthly. Again, only $23 \%$ of the monthly permits were completed. The distribution for the monthly totals is similar to the quarterly totals. Figure 2.2 shows that the monthly permits and completes diverge after the third quarter.

IABLE 2.4. Permits and Completes by Quarter for WSECP Participants

\begin{tabular}{||l|c|c|c|c|c||}
\hline Quarter & $\begin{array}{c}\text { \# Jurisdictions } \\
\text { Reporting }\end{array}$ & $\begin{array}{c}\text { Total } \\
\text { Permits }\end{array}$ & $\begin{array}{c}\text { Cumulative } \\
\text { Permits }\end{array}$ & $\begin{array}{c}\text { Total } \\
\text { Completes }\end{array}$ & $\begin{array}{c}\text { Cumulative } \\
\text { Completes }\end{array}$ \\
\hline \hline Q01 & 42 & 265 & 265 & 6 & 6 \\
\hline Q02 & 54 & 373 & 638 & 25 & 31 \\
\hline Q03 & 88 & 980 & 1618 & 123 & 154 \\
\hline Q04 & 108 & 1939 & 3557 & 292 & 446 \\
\hline Q05 & 116 & 1897 & 5454 & 801 & 1247 \\
\hline TOTAL & \multicolumn{7}{|l}{5454} & & 1247 & \\
\hline Source: & $\begin{array}{l}\text { Personal communication with Alan Mountjoy-Venning, WSE0, } \\
\text { September 1992 - January 1993. }\end{array}$ \\
\hline
\end{tabular}




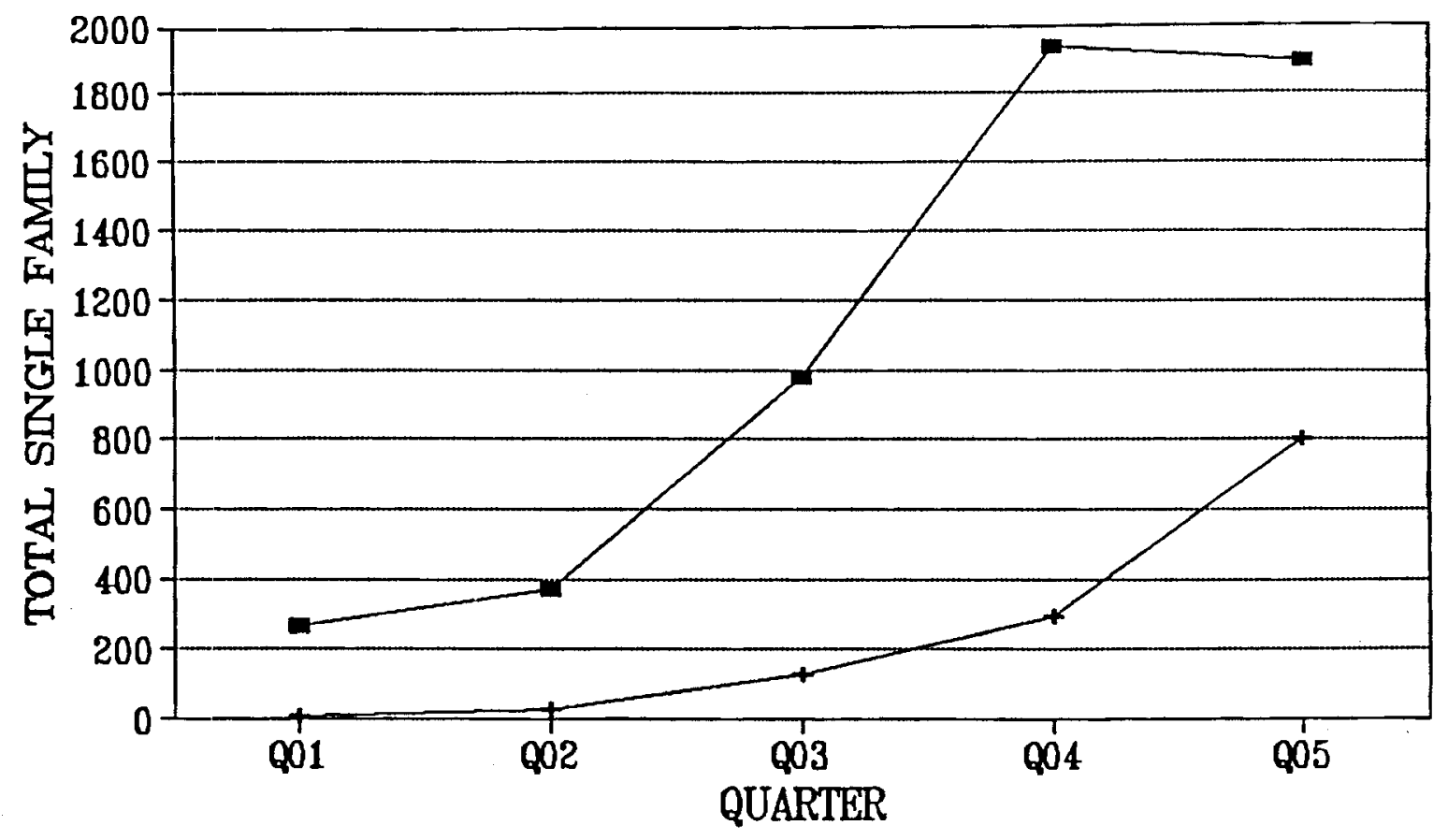

$\rightarrow-$ PERMIS $\multimap$ COMPLETES

FIGURE 2.1. WSECP Building Activity - Cumulative Single-Family by Quarter 
IABLE 2.5. Permits and Completes by Month for WSECP Participants

\begin{tabular}{|c|c|c|c|c|c|}
\hline Month & $\begin{array}{l}\text { \# Jurisdictions } \\
\text { Reporting }\end{array}$ & $\begin{array}{l}\text { Total } \\
\text { Permits }\end{array}$ & $\begin{array}{l}\text { Cumulative } \\
\text { Permits }\end{array}$ & $\begin{array}{l}\text { Total } \\
\text { Completes }\end{array}$ & $\begin{array}{l}\text { Cumulative } \\
\text { Completes }\end{array}$ \\
\hline MO1 & 3 & 42 & 42 & 0 & 0 \\
\hline MO2 & 4 & 43 & 85 & 0 & 0 \\
\hline MO3 & 3 & 42 & 127 & 0 & 0 \\
\hline M04 & 6 & 69 & 196 & 0 & 0 \\
\hline M05 & 5 & 44 & 240 & 2 & 2 \\
\hline M06 & 5 & 49 & 289 & 6 & 8 \\
\hline M07 & 10 & 107 & 396 & 13 & 21 \\
\hline M08 & 9 & 84 & 480 & 27 & 48 \\
\hline MO9 & 10 & 250 & 730 & 20 & 68 \\
\hline M10 & 14 & 289 & 1019 & 25 & 93 \\
\hline M11 & 11 & 302 & 1321 & 32 & 125 \\
\hline M12 & 11 & 332 & 1653 & 46 & 171 \\
\hline M13 & 14 & 291 & 1944 & 137 & 308 \\
\hline M14 & 11 & 260 & 2204 & 126 & 434 \\
\hline M15 & 12 & 253 & 2457 & 134 & 568 \\
\hline TOTAL & & 2457 & & 568 & \\
\hline Source: & \multicolumn{5}{|c|}{$\begin{array}{l}\text { Personal communication with Alan Mountjoy-Venning, WSEO, } \\
\text { September } 1992 \text { - January } 1993 \text {. }\end{array}$} \\
\hline
\end{tabular}




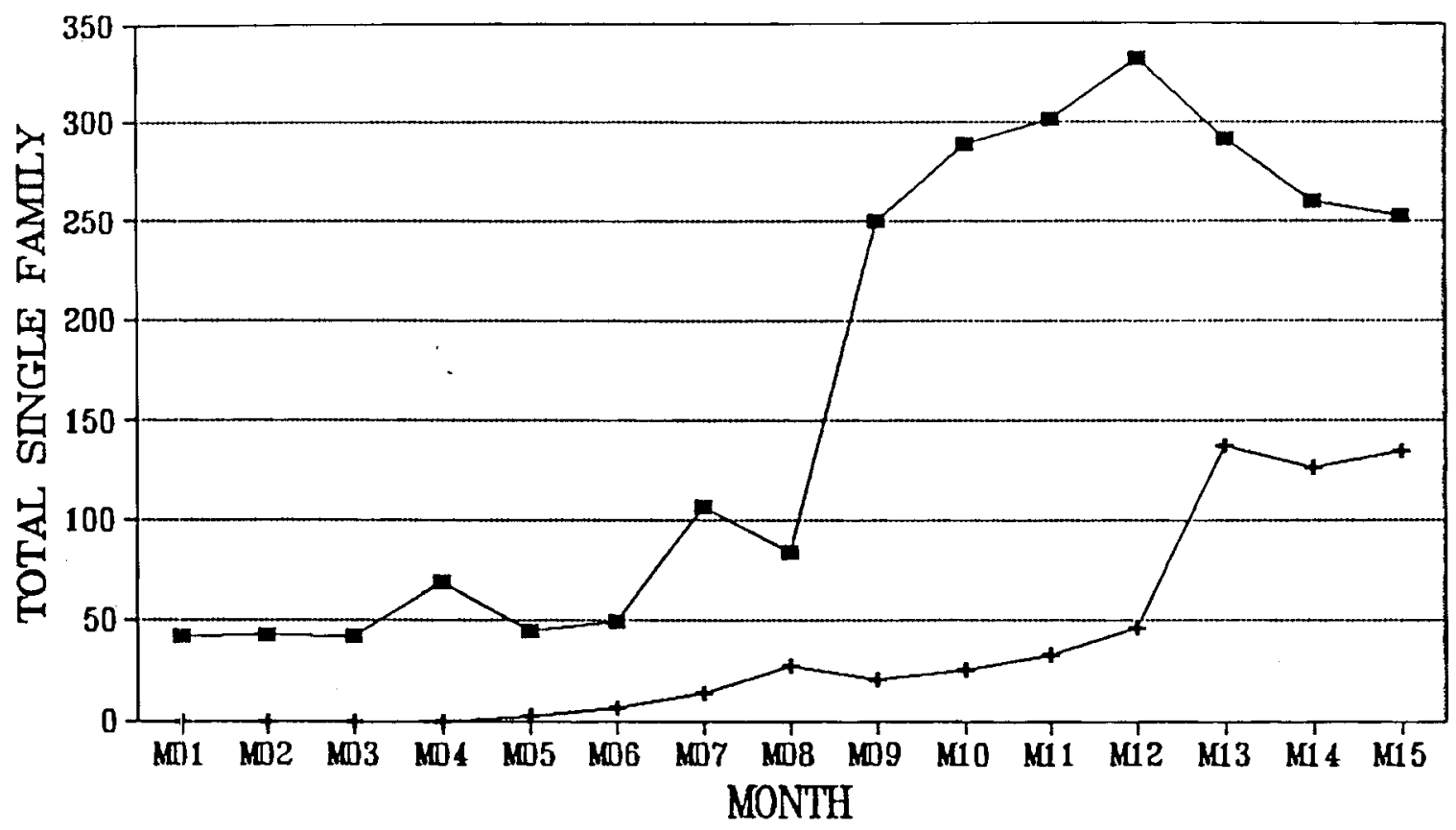

\section{$\rightarrow-$ PERMITS $\rightarrow$ COMPLETES}

FIGURE 2.2. WSECP Building Activity - Cumulative Single-Family by Month 
.

,

. 


\subsection{FIELD WORK}

The field inspection portion of this study conducted by PNL was designed to provide an auxiliary verification of the existing residential field inspection procedures being used by WSEO. The PNL evaluation report was initiated in July 1992. The WSEO Monitoring Plan provided a foundation for this evaluation in that it already included a sampling plan and field data collection instruments. PNL's proposal for this evaluation assumed that if these were adequate for purposes of the evaluation it would not be necessary to duplicate the efforts of WSEO in these specific areas. Accordingly, the first tasks PNL conducted were to review the adequacy of existing sampling plans and the WSEO protocols for field inspections, including the Construction Site Checklist, implementation instructions and training, and field implementation practices. PNL also conducted a sample of independent inspections similar to those conducted by WSEO. These inspections provide a similar set of data points for basic comparison as well as additional data for use in energy-savings modelling assessment.

\subsection{APPROACH: WSEO'S MONITORING PLAN}

The WSECP included a Quality Assurance Plan through which WSEO provides systematic oversight, monitoring, and measurement of code acceptance during the life of the WSEC program. The Quality Assurance and Monitoring Plans were developed collaboratively by WSEO, Bonneville, jurisdictions (including state associations of cities and of counties), and selected code officials, utilities and housing industry representatives. WSEO developed a Monitoring Plan to track acceptance of the WSEC through construction site visits using a standardized checklist. Because participation in the WSEC program provided WSEO with access to code officials in participating jurisdictions, the Monitoring Plan focused only on jurisdictions participating in the program. The WSEO Monitoring Plan was adopted in the Spring of 1992 for implementation beginning July 1, 1992 (Appendix A). 


\subsection{SAMPLING PLAN}

The sampling plan for any survey of new construction activity is prospective by nature because the population of buildings that the sample will represent are yet to be constructed and thus are unknown. Several sources of information were used by WSEO to develop its sampling $p l a n$. Two of these, past construction activity and building permits, were critical. Available data on construction activity is discussed in Section 2 of this report.

\subsubsection{Sample Size and Distribution}

The WSEO Monitoring Plan proposed a total sample of 150 single-family homes in 40 jurisdictions. The sites were distributed among jurisdictions of high, moderate, and low construction activity as shown in Table 3.1.

IABLE 3.1. WSEO 1992-93 Construction Season Site Inspection Sample Goal

\begin{tabular}{||c|c|c|}
\hline $\begin{array}{c}\text { Construction } \\
\text { Activity }\end{array}$ & Jurisdiction Sample Anticipated & $\begin{array}{c}\text { Anticipated Number of } \\
\text { Unit Inspections }\end{array}$ \\
\hline High & Al1 25 & 90 \\
\hline Moderate & 10 & 50 \\
\hline Low & 5 & 10 \\
\hline
\end{tabular}

WSEO's field inspections were to be carried out over 12 months beginning July 1, 1992. Initially, it was anticipated that the bulk of homes constructed for the July 1992 through June 1993 period would be available for inspection early in the monitoring period and would provide a large fraction of the 150 inspections to guide this evaluation by the Fall of 1992. However, the recession, rising lumber prices, and other factors slowed new construction, resulting in fewer early site inspections than hoped for. As a consequence, the schedule for this evaluation was extended. The number and distribution of WSEO site inspections included in this evaluation is found in Table 3.2. 
IABLE 3.2. Construction Site Inspections to Date (3-93)

\begin{tabular}{||l|c|c|}
\hline Strata & Jurisdictions Sampled & Units Inspected \\
\hline High & 16 & 71 \\
\hline Moderate & 10 & 45 \\
\hline Low & 4 & 12 \\
\hline
\end{tabular}

\subsubsection{PNL Review of WSEO Sampling Plan}

After reviewing available data on construction activity, PNL staff concluded that WSEO's sampling plan was reasonable to accomplish the objectives of the Monitoring Plan, especially since WSEO intends to repeat this inspection schedule annually for the next five years.

The total sample size and resultant geographic distribution of the sample was adequate for the general purposes of this evaluation but insufficient to draw statistically robust conclusions, particularly on a geographic or jurisdiction level. An alternative is to significantly expand the sample size and/or significantly revise the site inspection process. This may not be feasible given the current volume of homes being built, as a statistically valid sample may require data collection of a large fraction of all electrically heated homes being built in "low" construction jurisdictions and expansion of the site inspections to jurisdictions not currently participating in the WSEC program. WSEO lacks the resources to expand their inspections to non-WSEC program jurisdictions.

\subsection{WSEO SITE INSPECTION PROCEDURES}

As part of initial evaluation efforts, PNL al so reviewed field procedures developed by WSEO and their implementation by WSEO staff to determine if the procedures could lead to bias.

WSEO worked closely with key code enforcement organizations to develop its site inspection procedures. This cooperation was critical to establish a level of respect and trust between WSEO staff and various code enforcement 
personnel and organizations, including staff in local jurisdictions and associations that represent code enforcement staff and industry such as the Washington State Association of Counties (WSAC), the Association of Washington Cities (AWC), and the Washington Association of Building Officials (WABO).

\subsubsection{Issues}

One of the major issues that WSEO needed to overcome early in the WSECP was clarification of its role with respect to building code enforcement. Local officials and code enforcement staff were concerned about potential liabilities that could arise from release of information about specific buildings, builders, or code staff. WSEO and Bonneville staff agreed to keep field data confidential and restrict access to information that might permit identification of specific inspections or inspectors.

Another issue was the adequacy of single visits to each site. Building inspections occur throughout the construction of a building rather than at one point in time. The foundation inspection occurs and the builder is then permitted to cover the foundation. Similarly, the insulation inspection permits the builder to cover the walls. As a result, an inspection at any point in time can only cover limited construction activities. WSEO recognized this in both its Monitoring $\mathrm{Pl}$ an and on the checklist, which lists five construction stages:

1. plan check

2. foundation

3. framing

4. insulation

5. final.

Actual verification of code compliance in a specific area could require multiple visits. For example, the initial insulation inspection may reveal incomplete insulation. This would be noted as "non-compliant" and a correction notice issued to the builder. This notice could be formal or informal. In either case, a re-inspection visit would be expected by the builder. If the re-inspection indicates the insulation problem has been corrected, the builder receives approval to cover the walls and advance to the next construction stage. WSEO only goes out on first inspections of each construction 
stage. Using the example cited, they would note the insulation errors. However, their procedures would not capture any later corrections. Although this approach provides an appropriate measure of compliance for both WSEO's Quality Assurance program and this evaluation, it tends to understate the final level of compliance (see Richman letter in Appendix C.

A third issue was selection of sites. As an alternative to having WSEO pick the sites and set the schedule for visits, WSEO decided to stratify its sample by inspection activity (e.g., foundation, insulation, windows and doors, etc.) and give each jurisdiction a target for the number and type of inspections WSEO wanted to conduct. The procedure to be followed would be for the code officials to contact WSEO prior to the target inspections then WSEO could accompany the code official on the enforcement visit. Although, this approach was ultimately adopted by WSEO, the concern was raised that code officials could "cherry pick" and only contact WSEO when they had a site with a high likelihood of compliance.

\subsubsection{WSEO-PNL Co-Inspections}

PNL reviewed WSEO's Monitoring Plan and accompanied WSEO staff on several early site visits to evaluate the reliability of WSEO's Construction Site Checklist (Appendix $B$ ) and field inspection procedures.

PNL Review of Checklist

PNL's findings indicated several minor areas for improvement in the procedures.

- The site checklist did not include space for recording total home square footage or component square footage such as for walls, floors, ceilings, windows, and doors. These values would be needed for detailed compliance modelling. An indication of conditioned versus overall square footage would also be needed.

- The variance types and categories noted in the procedure appeared to be appropriate for code compliance assessment. However, to fully assess compliance deficiencies, it may be necessary to identify specific code discrepancies or shortcomings. The current checklist only provided spaces for checking the level of compliance as described in the 
procedure. It would be more instructive to be able to specifically and consistently identify the actual code variances that create the compliance level.

- To assist code officials or builders in complete compliance, it would be useful to be able to site specific building practices that may be recurring compliance deficiencies. This requires that specific building practices or oversights that contribute to the noted variances be recorded.

- Since it is acknowledged that inspection is as much an art as a science, it is recommended that the WSEO auditors compare notes concerning inspection details. This would help ensure that consistent code variances are being applied to consistent code deficiencies.

PNL recommendations were partly conveyed through a letter to WSEO, which is included as Appendix D. A sample format of a checklist that included spaces for the additional items noted above was also relayed to WSEO.

\section{WSEO Response}

WSEO responded to these comments by adopting the recommendations, and immediately implementing the recommended changes. For example, existing checklists were modified by hand to reflect the recommended changes while new forms were printed. The revised checklist included space for additional details on compliance faults and general compliance notes. Spaces for square footages were not included, but may be included in next year's Monitoring Checklist. The comparison of notes between the WSEO inspectors was already in place and was continuing on a weekly basis.

Subsequently, PNL staff accompanied WSEO staff on several site inspections. PNL concluded from these co-inspections that the WSEO Monitoring Plan site inspection procedures were reliable and appropriate for the purposes of both quality assurance for the WSEC program and for data collection for this evaluation. Additionally, it was noted that the approach recommended by code officials to WSEO closely mirrors the actual code enforcement process, because the code official and the WSEO field inspector are inspecting the site at the same time. As a result, the WSEO inspector is able to view violations as they are discovered by the code inspector. This provides insurance against initial concerns of "cherry picking." 


\subsection{PNL INDEPENDENT SITE INSPECTIONS}

An arrangement was reached between PNL, WSEO, AWC, and WSAC for PNL to participate in several independent site inspections that were not attended by WSEO staff. The purpose of these visits was to collect comparable data to use to check for possible bias. PNL made arrangements with each of the building officials in selected jurisdictions and asked to be notified of energy-related inspections. In most cases a weekly phone call was made to each area to identify inspections available that week. In a few cases building officials would call with notice of inspections. Some difficulty was encountered in connecting with inspectors for some inspections because the inspections are typically scheduled and completed on very short notice (4 to 48 hours) and PNL staff were not always able to get to the inspection sites in time.

When PNL staff were able to make the inspection, the building official was met at the site or office. If $p l$ ans were available, they were reviewed. The inspection of energy code items at the site was completed by PNL staff by accompanying the building official and often the builder while they made their scheduled inspection. Any questions about code by the building official or builder were generally referred to WSEO contacts. Site inspections were conducted using the same checklist used in WSEO inspections. The same energy code items were inspected as in the WSEO site inspections. PNL staff noted that this checklist was not originally intended to evaluate the program or determine code compliance; it was prepared to identify compliance topics and jurisdictions that could benefit from additional training.

PNL completed independent site inspections at 21 different sites within 7 different building code jurisdictions. Many of the inspections included multiple components (walls, ceilings, windows, etc.). Although the focus of this task is on electrically heated homes, a few gas-heated residences were inspected in order to complete enough inspections in the allotted time and because many of the current housing starts in the available jurisdictions are gas heated. The general envelope (insulation, windows, doors), air leakage control, and ventilation code requirements are the same regardless of heating type. 
The residences inspected generally followed WSEC requirements. In a few cases, serious deficiencies were found (a "4" rating in the WSEO checklist). In these cases the local code official present at the inspection identified these deficiencies as part of the inspection process. Because of this, it is believed that virtually all of the major discrepancies were eventually brought to code compliance to the satisfaction of the building official.

One common theme among the residences found to have variances was poor quality in the installation of energy measures. Example of poor quality included:

- compacted insulation around ductwork

- compacted or loose insulation in floors

- lack of insulation support in underflooring

- insulation gaps at ducting boots and elbows.

It is not known how many of these "quality" items were corrected. In many cases the quality of an installation may not appear to be at variance with the code and therefore may not be identified as an item needing repair.

In the course of completing the inspections, several comments were received from local building officials. Some comments were replies to general queries by PNL inspectors about their perceptions and concerns about the program. Other comments were unsolicited and offered in the course of general conversation about energy conservation and codes. These comments were generally consistent with those received during the telephone interviews reported in Chapter 5. The comments received are paraphrased in Appendix I. One comment that was of concern was the claim from a WSECP participating jurisdiction that they did not have a computer and therefore could not use the WATTSUN software. This jurisdiction is in a high-growth area and presumably should have been equipped with a computer under the WSECP.

\subsection{ANALYSIS OF SITE INSPECTION DATA}

The site inspection procedures adopted by WSEO are geared toward specific stages of construction rather than specific sites. This approach prevents the development of site-specific indices (e.g., this site is within $90 \%$ of 
code compliance). Instead, compliance had to be summarized across sites and compliance topics (insulation, windows and doors, etc.). The specific indices are described in Chapter 4 . Component checklist results were averaged for compliance with construction standards across all sites. This provides an indicator of overall component compliance level and reveal categorical compliance problems. However, an average for any single measure, or even for all measures combined, does not provide a summary result on a building basis. A compilation of building-based summary statistics requires a "simulation" of a typical building that uses the compliance results for each component, weighted to reflect the contribution each component has on energy use. These analyses were conducted to generate categorical and building-level indices for comparison of variations in compliance based on geography, level of building activity, and other factors.

Categorical indices provide an indication of the mean and variance of compliance for each category. Comparison of these statistics across categories provides an indication of where compliance and enforcement is good and where it is weak and more training may be needed. This should be sufficient to provide guidance for future program activities. Another index is needed to represent the overall effect of current levels of compliance on the energy savings objectives of the WSEC. This index is composed of a composite of the categorical indices that represent a "typical" house. For example, the relative importance of a low compliance with slab insulation and high compliance with windows and doors and other insulation is only evident when compared directly in a sample home.

This typical home was developed based on field data for square footage, window and door area, etc. The categorical compliance statistics were used to simulate the performance of this prototype with the deviations in compliance reflected in each categorical measure (e.g., $80 \%$ compliance with ceiling insulation would be reflected as $80 \%$ of the code-required insulation and so on). This procedure provides both an overall metric for code compliance and a perspective on the reliability of codes as an indicator of measure installation 
and energy performance. This latter information is necessary as Bonneville sets out to evaluate the impacts and energy savings effectiveness of the WSEC and other codes.

The goal of the WSECP is to facilitate the transition to the WSEC and increase the rate of WSEC code compliance. There is no historical data on levels of code compliance other than responses to surveys of code officials and others and inspection reports on file at local jurisdictions. The role of WSEO in code enforcement and its relationship to code enforcement jurisdictions does not provide it with access to code enforcement data except through participants in the WSECP. As a result, there is no "control" group of non-WSEC participants readily available for comparison purposes. Accordingly, for this evaluation, code compliance is measured by comparing compliance rates among WSECP jurisdictions grouped by previous code experience. Conclusions about the effectiveness of current code enforcement practices and the training provided by the WSEC are presented in reference to these comparisons. This is in contrast to historic levels of energy code compliance, compliance with other building codes, and so on.

Specific findings from an analysis of the data collected during inspections conducted by the WSEO as part of its WSEC Monitoring Plan are described in Chapter 4. Results of the analysis of the data collected by PNL during its site inspections are presented in Section 4.3. 


\subsection{WSEO SITE INSPECTION DATA ANALYSIS}

Construction site data collected by WSEO under the Monitoring Plan was used by PNL to evaluate code compliance. WSEO provided PNL with data collected using the standardized checklist in Appendix B. The site inspection procedures adopted by WSEO are geared toward specific stages of construction rather than specific building sites. This approach prevents the development of site-specific indices (e.g., this site is within $90 \%$ of code compliance). Instead, compliance was summarized across construction sites and building components. Categorical and building-level indices were developed for the program as a whole, and for sub-categories based on geographic location, building activity, and energy code history.

Categorical indices were developed using the construction "stages" identified on the WSEO monitoring checklists (i.e., slab insulation, wall insulation, windows and doors, etc.). Field inspection logistics prevented WSEO from inspecting each stage of construction at each site. As a result, the categorical site inspection data provides useful information about code compliance at specific stages of construction and how these vary across Washington state. Although this is useful, it does not provide a clear evaluation of code compliance at the building level or the effect non-compliances may have on energy use. For this reason, PNL transformed component site inspection data into energy use indices that could be summed across sites to create a composite index of energy use. Component and overall UA(a) values were calculated using the standard heat loss models and assumptions used by the Northwest Power Planning Council (the Council) and Bonneville.

\subsection{METHODOLOGY}

The WSEO construction site checklist rates code compliance for each building component on a scale of 1 to 4 . A rating of " 1 " means that the component fully complied with the WSEC. WSEO identified typical non-compliance features (e.g., incomplete insulation) and assigned these a "non-compliance"

(a) The UA value is the overall rate of heat flow through a combination of materials, air layers, and air spaces. 
rating ranging from 2 to 4 . The lowest rating of "4" does not equate to total non-compliance, because the scale still includes minimum energy conservation measures. For each building component the compliance ratings were translated into an insulation level reduction as defined in the WSEO Monitoring Plan (see Table 4.1). The radon detector and plan review categories were not relevant to the analysis. (Radon doesn't affect building shell efficiency and plan reviews are only relevant for homes that use the system analysis path. Fewer than 1 in 100 homes were built using that approach.) Similarly, the duct insulation, ventilation, and air leakage control categories are difficult to quantify in terms of $U$-value, a static measure of heat transfer. Thus, they were ignored in the $U$-value analysis.

TABLE 4.1. Code Compliance Rating Insulation Levels Used in Analysis

\begin{tabular}{|c|c|c|c|c|}
\hline Component & Leve1 1 & Level 2 & Level 3 & Level 4 \\
\hline Slab & $\begin{array}{l}100 \% \\
\text { insulated }\end{array}$ & $\begin{array}{l}2 \% \text { perimeter } \\
\text { uninsulated }\end{array}$ & $\begin{array}{l}\text { 6\% perimeter } \\
\text { uninsulated }\end{array}$ & $\begin{array}{l}11 \% \text { perimeter } \\
\text { uninsulated }\end{array}$ \\
\hline Floor & $\begin{array}{l}100 \% \\
\text { insulated }\end{array}$ & $\begin{array}{l}3 \% \text { area } \\
\text { uninsulated }\end{array}$ & $\begin{array}{l}6 \% \text { area } \\
\text { uninsulated }\end{array}$ & $\begin{array}{l}6 \% \text { area uninsulated } \\
\text { and } \\
6 \% \text { area } 1 / 3 \mathrm{R}- \\
\text { value }\end{array}$ \\
\hline Wall & $\begin{array}{l}100 \% \\
\text { insulated }\end{array}$ & $\begin{array}{l}3 \% \text { area } \\
\text { uninsulated }\end{array}$ & $\begin{array}{l}6 \% \text { area } \\
\text { uninsulated }\end{array}$ & $\begin{array}{l}6 \% \text { area uninsulated } \\
\text { and } \\
6 \% \text { area } 1 / 3 \mathrm{R}- \\
\text { value }\end{array}$ \\
\hline Ceiling & $\begin{array}{l}100 \% \\
\text { insul ated }\end{array}$ & $\begin{array}{l}3 \% \text { area } \\
\text { uninsulated }\end{array}$ & $\begin{array}{l}6 \% \text { area } \\
\text { uninsulated }\end{array}$ & $\begin{array}{l}6 \% \text { area uninsulated } \\
\text { and } \\
6 \% \text { area } 1 / 3 \mathrm{R} \text { - } \\
\text { value }\end{array}$ \\
\hline $\begin{array}{l}\text { Windows } \\
\text { and Doors }\end{array}$ & $\begin{array}{l}100 \% \text { U-value } \\
\text { rating }\end{array}$ & $\begin{array}{l}11 \% \text { U-value } \\
\text { deviation }\end{array}$ & $\begin{array}{l}21 \% \text { U-value } \\
\text { deviation }\end{array}$ & $\begin{array}{l}30 \% \text { U-value } \\
\text { deviation }\end{array}$ \\
\hline
\end{tabular}

Ideally, field data for building square footage and component area would be used to calculate the UA value. Unfortunately, this data was not available during the site inspections. (This data is only routinely collected for homes using the system analysis path.) The standard heat loss models used by the Council and Bonneville are based on prototypical building characteristics for a small, medium, and large sized home. The prototypes are listed in 
Appendix E. These prototype characteristics were substituted for field measurements and the analyses conducted using checklist observations. These analyses were conducted for each of the three prototypes. The individual building components listed on the site inspection checklist (e.g., wall, floor, ceiling, etc.) and overall UA values were calculated for the categorical and building-level indices. This approach has the advantage of being calibrated to a benchmark that does not vary from county to county based on house size differences.

\subsubsection{Benchmark}

A thermal performance benchmark must be established to measure the variation in code compliance. The benchmark should be derived from the WSEC requirements. However, code compliance can be achieved by three different methods, the system analysis, thermal performance, and prescriptive paths. The thermal characteristics vary with each method. The system analysis path requires the use of a building simulation program to calculate the annual energy consumption to meet compliance. This method accounts for the building's specific characteristics such as the thermal mass and solar orientation. Since this information was unavailable, and only $1 \%$ of the inspections used the system analysis compliance method, those sites were excluded in the UA value analysis because results would not be statistically meaningful.

The thermal performance compliance path allows the U-value of one component to be reduced if another component $U$-value is increased such that the total heat gain or loss is unaffected. For example, a builder can use a window that is below the target $U$-value as long as the incremental energy loss through the window is offset by additional insulation in another component such as the ceiling. The incentive for the builder is that the extra insulation is cheaper than the high-performance windows. Over half of the inspections, 56\%, used the thermal performance compliance path. The target U-values listed in the WSEC would provide a convenient benchmark.

The prescriptive path compliance method specifies design and material characteristics such as insulation levels rather than an overall performance level. The prescriptive path was used by $43 \%$ of the site inspections. The WSEO lists eight prescriptive requirement options which vary by glazing area 
(ranging from $10 \%$ to $30 \%$ of glazing area to floor area). The eight options specify different sets of envelope component $R$-value requirements. The prescriptive path option IV thermal characteristics, listed in Table 4.2, are identical to the target component $U$-values of the thermal performance compliance method and were used for the code compliance energy component analysis.

TABLE 4.2. Data Analysis Benchmark Thermal Characteristics

\begin{tabular}{||l|c|c|}
\hline Component & Climate Zone 1 & Climate Zone 2 \\
\hline \hline Glazing (\% Floor Area) & $15 \%$ & $15 \%$ \\
\hline Glazing U-Value & 0.40 & 0.40 \\
\hline Door U-Value & 0.20 & 0.20 \\
\hline Ceiling Insulation & $\mathrm{R}-38$ & $\mathrm{R}-38$ \\
\hline Above-Grade Wall Insulation & $\mathrm{R}-19$ & $\mathrm{R}-19+\mathrm{R}-5$ \\
\hline Below-Grade Interior Wall Insulation & $\mathrm{R}-19$ & $\mathrm{R}-21$ \\
\hline Below Grade Exterior Wall Insulation & $\mathrm{R}-10$ & $\mathrm{R}-12$ \\
\hline Floor Insulation & $\mathrm{R}-30$ & $\mathrm{R}-30$ \\
\hline Slab On Grade Insulation & $\mathrm{R}-10$ & $\mathrm{R}-10$ \\
\hline
\end{tabular}

\subsubsection{Component UA Calculation Method}

Residential energy simulation software, such as SUNDAY or WATTSUN can be used to calculate the overall rate of heat flow. However, they require much more detail than was available. Therefore a simplified hand calculation was employed using the small, medium, and large- sized building prototype and benchmark thermal characteristics. Appendix $F$ details the assumptions, analysis, and UA values.

The overall UA values associated with $100 \%$ compliance, level 1 , and a fraction of total compliance, levels 2 through 4 , are listed in Table 4.3. They are categorized by climate zone, prototype size, and floor construction. It is assumed that the foundation construction is either a slab-on-grade or crawl space. Four percent of the sites listed a compliance level for both slab and floor insulation, these sites were omitted from the analysis. 
IABLE 4.3. Prototype Total UA Values by Compliance Level and Climate Zone

\begin{tabular}{||c|c|c|c|c|c|c|c|c||}
\hline \hline $\begin{array}{l}\text { Compl iance } \\
\text { Level }\end{array}$ & \multicolumn{2}{|c|}{1} & \multicolumn{2}{c|}{2} & \multicolumn{2}{c|}{3} & \multicolumn{2}{c||}{4} \\
\hline $\begin{array}{l}\text { Cl imate } \\
\text { Zone }\end{array}$ & 1 & 2 & 1 & 2 & 1 & 2 & 1 & 2 \\
\hline \hline $\begin{array}{l}\text { Smal1 } \\
\text { (Slab) UA }\end{array}$ & 374 & 364 & 426 & 417 & 472 & 464 & 500 & 491 \\
\hline $\begin{array}{l}\text { Medium } \\
\text { (Slab) UA }\end{array}$ & 446 & 431 & 503 & 491 & 556 & 543 & 588 & 574 \\
\hline $\begin{array}{l}\text { Large } \\
\text { (Slab) UA }\end{array}$ & 540 & 530 & 622 & 613 & 693 & 684 & 734 & 724 \\
\hline $\begin{array}{l}\text { Smal1 } \\
\text { (Craw1) UA }\end{array}$ & 312 & 303 & 362 & 354 & 406 & 398 & 431 & 422 \\
\hline $\begin{array}{l}\text { Medium } \\
\text { (Craw1) UA }\end{array}$ & 392 & 378 & 449 & 437 & 499 & 487 & 528 & 514 \\
\hline $\begin{array}{l}\text { Large } \\
\text { (craw1) UA }\end{array}$ & 483 & 473 & 563 & 554 & 632 & 623 & 670 & 660 \\
\hline
\end{tabular}

\subsection{WSEO SITE INSPECTION DATA ANALYSIS RESULTS}

WSEO provided PNL with 128 site inspection checklists conducted in 40 participating jurisdictions. The checklists building component compliance ratings (i.e., 1 through 4 ) were averaged and categorized by total number of inspections, jurisdiction's energy code history, construction activity, and geographic location. The individual building component compliance ratings were used to quantify the thermal performance by defining an overall building UA value. A small, medium, and large-sized prototype was used. The results were then averaged and categorized by the same criteria as the building component compliance ratings.

\subsubsection{Building Component Results}

Table 4.4 lists the average component compliance level from the 128 site inspections. Since the inspections were conducted at various construction stages, all building components were not inspected at each site. Figure 4.1 graphically displays the component compliance ratings, where a rating greater 
than " 1 " indicates decreasing compliance (i.e., missing insulation). The lowest compliance level (highest rating), was found in the slab component with an average rating of 2.50. According to the WSEC monitoring checklist rating description, a 2.50 would only have a minor impact on energy performance. The windows and doors had the best compliance with an average rating of 1.33.

TABLE 4.4. Average Component Compliance Rating

\begin{tabular}{||l|c|c||}
\hline \multicolumn{1}{|c|}{ Component } & $\begin{array}{c}\text { Total Average } \\
\text { Compliance }\end{array}$ & $\begin{array}{c}\text { Total \# of } \\
\text { Sites }\end{array}$ \\
\hline \hline Slab & 2.50 & 20 \\
\hline Floor & 2.03 & 37 \\
\hline Wall & 2.21 & 43 \\
\hline Ceiling & 1.83 & 30 \\
\hline Windows & 1.33 & 101 \\
\hline Doors & 1.33 & 101 \\
\hline Duct & 1.71 & 21 \\
\hline \hline Total \# of Sites Inspected & 128 \\
\hline Total \# of Jurisdictions Inspected & 40 \\
\hline
\end{tabular}

It is presumed that builders and inspectors with previous energy code experience (i.e., SGC and/or NWEC) and training should have a better compliance score (lower rating). The 128 sites inspected were from 40 jurisdictions which all had utilities that participated in the SGC program. Table 4.5 lists the average compliance rating from sites that had not participated in the NWEC (Path A) and sites that had participated in the NWEC (Path B). Approximately $61 \%$ of the site inspections were in jurisdictions with code Path A (non-NWEC participant) and $39 \%$ were in jurisdictions with code Path B (NWEC participant). Figure 4.2 is a graphical representation of the results. Except for the ceiling and floor components, jurisdictions with previous NWEC experience had better compliance scores (lower rating). Overall, there was a high level of code compliance. 


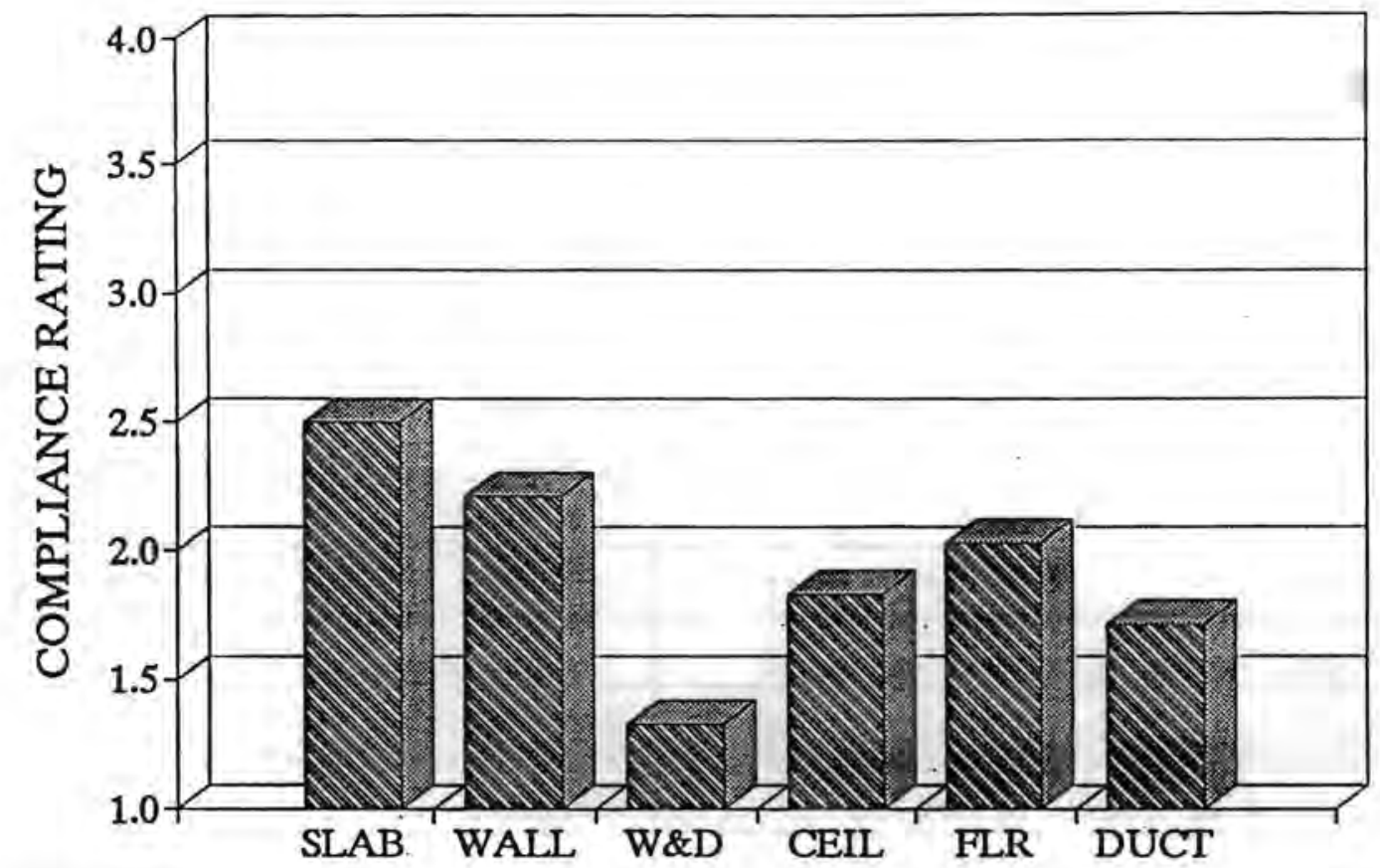

FIGURE 4.1. Average Compliance Rating from 128 WSEO Site Inspections

It is also presumed that building activity would affect the level of code compliance. Jurisdictions with high construction activity should have better code compliance than those with moderate to low activity. Jurisdictions with 50 or more single-family electrically heated housing starts for 1991 were classified as having high building activity. Those with five or more were classified as having moderate activity, and those with less than five starts were classified as low activity. Table 4.6 lists the average compliance rating for each building activity level. Approximately $55 \%$ of the site inspections were from jurisdictions with high building activity, $35 \%$ were moderate activity, and $10 \%$ were low activity. As seen in Figure 4.3 , there doesn't seem to be a correlation between building activity and code compliance. 
TABLE 4.5. Average Component Compliance Rating Categorized by Energy Code History

\begin{tabular}{||l|c|c|c|c||}
\hline \multirow{2}{*}{\multicolumn{1}{|c|}{ Component }} & \multicolumn{2}{c|}{ PATH A } & \multicolumn{2}{c||}{ PATH B } \\
\cline { 2 - 5 } & $\begin{array}{c}\text { Average } \\
\text { Compliance }\end{array}$ & $\begin{array}{c}\text { \# of } \\
\text { Sites }\end{array}$ & $\begin{array}{c}\text { Average } \\
\text { Compliance }\end{array}$ & $\begin{array}{c}\text { \# of } \\
\text { Sites }\end{array}$ \\
\hline \hline Slab & 2.64 & 14 & 2.17 & 6 \\
\hline Floor & 1.95 & 22 & 2.13 & 15 \\
\hline Wal1 & 2.33 & 24 & 1.95 & 20 \\
\hline Ceiling & 1.75 & 16 & 1.93 & 14 \\
\hline Windows & 1.41 & 63 & 1.18 & 38 \\
\hline Doors & 1.41 & 63 & 1.18 & 38 \\
\hline Duct & 1.76 & 17 & 1.50 & 4 \\
\hline \hline Total \# of Sites Inspected & 78 & & 50 \\
\hline Total \# of Jurisdictions Inspected & 28 & & 12 \\
\hline \hline $\begin{array}{l}\text { PATH A = Former SGC part icipant } \\
\text { PATH B = Former SGC and NWEC participant }\end{array}$ \\
\hline
\end{tabular}

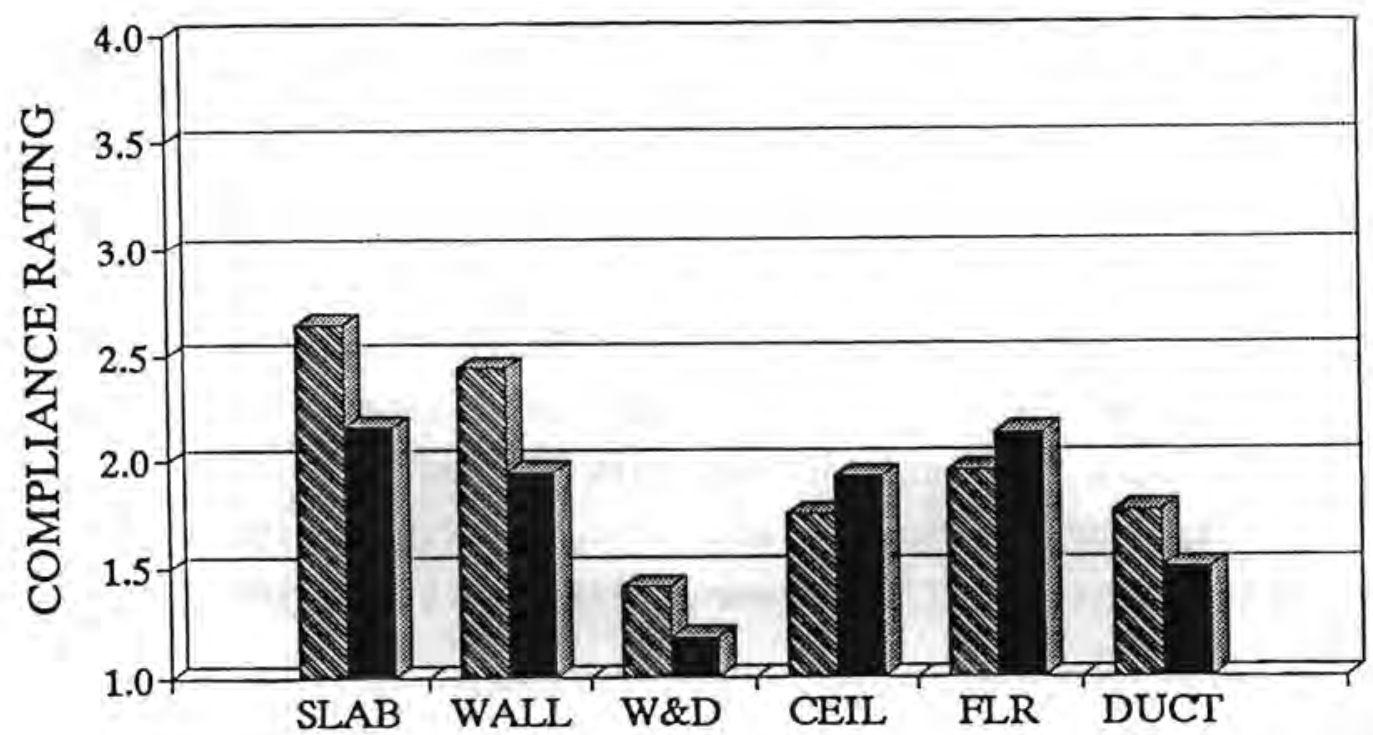

$S G C=>$ WSEC

SGC $=>$ NWEC $=>$ WSEC

FIGURE 4.2. Average Compliance Rating by Code History 
TABLE 4.6. Average Component Compliance Rating Categorized by Building Activity

\begin{tabular}{|c|c|c|c|c|c|c|}
\hline \multirow[b]{2}{*}{ Component } & \multicolumn{2}{|c|}{ HIGH } & \multicolumn{2}{|l|}{ MOD } & \multicolumn{2}{|c|}{ LOW } \\
\hline & $\begin{array}{c}\text { Average } \\
\text { Compliance }\end{array}$ & $\begin{array}{l}\text { \# Of } \\
\text { Sites }\end{array}$ & $\begin{array}{c}\text { Average } \\
\text { Compliance }\end{array}$ & $\begin{array}{l}\text { \# of } \\
\text { Sites }\end{array}$ & $\begin{array}{c}\text { Average } \\
\text { Compliance }\end{array}$ & $\begin{array}{l}\text { \# of } \\
\text { Sites }\end{array}$ \\
\hline Slab & 2.20 & 10 & 2.80 & 10 & NA & 0 \\
\hline Floor & 2.27 & 22 & 1.70 & 10 & 1.60 & 5 \\
\hline Wall & 2.10 & 30 & 2.43 & 7 & 2.50 & 6 \\
\hline Ceiling & 1.91 & 22 & 1.63 & 8 & NA & 0 \\
\hline Windows & 1.51 & 51 & 1.13 & 39 & 1.18 & 11 \\
\hline Doors & 1.51 & 51 & 1.13 & 39 & 1.18 & 11 \\
\hline Duct & 1.58 & 12 & 2.40 & 5 & 1.25 & 4 \\
\hline \multicolumn{2}{|c|}{ Total \# of Sites Inspected } & 71 & & 45 & & 12 \\
\hline \multicolumn{2}{|c|}{$\begin{array}{l}\text { Total \# of Jurisdictions } \\
\text { Inspected }\end{array}$} & 20 & & 16 & & 4 \\
\hline \multicolumn{7}{|c|}{$\begin{array}{l}\text { HIGH = High building activity }-50 \text { or more single-family electrically } \\
\text { heated housing starts per year. } \\
\text { MOD = Moderate building activity }-5 \text { or more single-family electric ally } \\
\text { heated housing starts per year. } \\
\text { LOW = Low building activity - Less than } 5 \text { single-family electrically } \\
\text { heated housing starts per year. }\end{array}$} \\
\hline
\end{tabular}

The geographic location of jurisdictions were al so thought to influence the level of code compliance. Table 4.7 lists the average component compliance rating for sites east and west of the Cascade Mountain Range. Only 34\% of the site inspections were from eastern jurisdictions while $66 \%$ were from the western region. Sites from jurisdictions east of the Cascades had a lower rating (higher compliance) than those from the west in every category except slab insulation where the east had a rating that was 0.24 higher (a worse rating), which shouldn't represent a significant energy impact. 


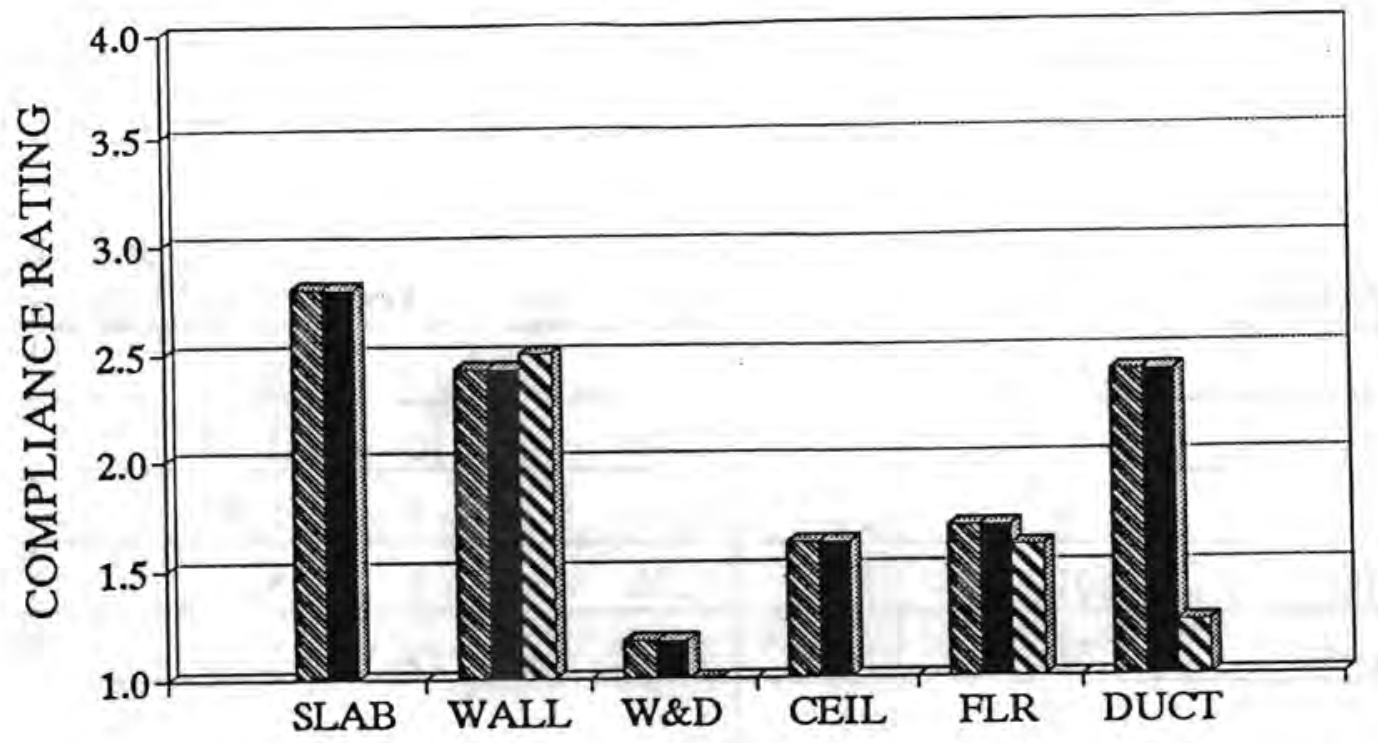

MIGH MODERATE MW LOW

FIGURE 4.3. Average Compliance Rating by building Activity

IABLE 4.7. Average Component Compliance Rating Categorized by Geographic Location

\begin{tabular}{||l|l|l|l|l||}
\hline \multirow{2}{*}{\multicolumn{1}{|c|}{ Component }} & \multicolumn{2}{c|}{ EAST } & \multicolumn{2}{c||}{ WEST } \\
\cline { 2 - 6 } & $\begin{array}{c}\text { Average } \\
\text { Compliance }\end{array}$ & $\begin{array}{c}\text { \# of } \\
\text { Sites }\end{array}$ & $\begin{array}{c}\text { Average } \\
\text { Compliance }\end{array}$ & $\begin{array}{c}\text { \# of } \\
\text { Sites }\end{array}$ \\
\hline \hline Slab & 2.67 & 6 & 2.43 & 14 \\
\hline Floor & 1.90 & 10 & 2.07 & 27 \\
\hline Wall & 1.87 & 15 & 2.39 & 28 \\
\hline Ceiling & 1.64 & 11 & 1.95 & 19 \\
\hline Windows & 1.19 & 36 & 1.40 & 65 \\
\hline Doors & 1.19 & 36 & 1.40 & 65 \\
\hline Duct & 1.58 & 12 & 1.89 & 9 \\
\hline \hline Total \# of Sites Inspected & 44 & & 84 \\
\hline Total \# of Jurisdictions Inspected & 11 & \multicolumn{2}{c||}{29} \\
\hline \hline $\begin{array}{l}\text { EAST }=\text { Jurisdictions located east of the Cascade Mountain Range. } \\
\text { WEST = Jurisdictions located west of the Cascade Mountain Range. }\end{array}$ \\
\hline
\end{tabular}




\subsubsection{Thermal Performance Simulation Results}

Table 4.8 summarizes the average small, medium, and large-sized prototype UA value categorized by jurisdiction energy code history, building activity, and geographic location. The average percent compliance column in Table 4.8 compares the calculated UA values to those values that represent $100 \%$ compliance in Table 4.3. The total compliance was $97 \%$. The lowest compliance was in the high building activity category with 95\%, which is still good.

TABLE 4.8. Average Percent Code Compliance Based on Prototype Overall UA Values

\begin{tabular}{|l|l|l|l|c|}
\hline \multicolumn{1}{|c|}{ Classification } & $\begin{array}{c}\text { Small } \\
\text { UA }\end{array}$ & $\begin{array}{c}\text { Medium } \\
\text { UA }\end{array}$ & $\begin{array}{c}\text { Large } \\
\text { UA }\end{array}$ & $\begin{array}{c}\text { Average } \\
\text { Compliance }\end{array}$ \\
\hline \hline TOTAL & 324 & 406 & 495 & $97 \%$ \\
\hline PATH A (SGC to WSEC) & 324 & 405 & 492 & $97 \%$ \\
\hline PATH B (SGC to NWEC to WSEC) & 325 & 406 & 499 & $96 \%$ \\
\hline HIGH Building Activity & 327 & 409 & 502 & $95 \%$ \\
\hline MODERATE Building Activity & 320 & 401 & 484 & $98 \%$ \\
\hline LOW Building Activity & 322 & 406 & 496 & $97 \%$ \\
\hline EAST of Cascades & 321 & 401 & 492 & $97 \%$ \\
\hline WEST of Cascades & 326 & 408 & 497 & $96 \%$ \\
\hline \hline UA = Overall UA value with units of Btu/hr*oF \\
\hline
\end{tabular}

According to the 128 construction site inspection checklists, the average compliance rating did not represent a significant energy compromise. The components with the best compliance rating were doors and windows. Slab insulation had the worst compliance, with an overall average rating of 2.50 , which still does not represent a major impact on energy performance. The inspection checklists were categorized by energy code history, building activity level, and geographic location. As expected, the jurisdictions with additional code experience had a lower (better) compliance rating for each component except for the ceiling and floor. There was no distinct pattern when the checklists were categorized by building activity. The jurisdictions west of the Cascade 
Mountain Range had a higher (worse) rating except for the slab insulation. This higher rating could be attributed to the fact that $66 \%$ of the checklists were from in western jurisdictions.

\subsection{PNL SITE INSPECTION DATA ANALYSIS RESULTS}

PNL staff conducted 21 independent site inspections in 5 different jurisdictions. These were in addition to those conducted jointly with WSEO earlier in the evaluation. PNL used the same data collection methodology as WSEO; however, PNL staff attempted to review multiple construction components rather than focusing on specific construction stages. As a result, we were able to collect data on windows and doors at all 21 sites as well as data on other components at other sites. Little data was collected on slab insulation because only 3 of the 21 sites had slab-on-grade construction.

The same methods PNL used to analyze the WSEO checklist data were used to analyze the data from these sites. The objective of both the independent site inspections and these analyses is to identify any differences in results that may indicate potential bias in the WSEO checklist data. The results from these analyses are presented in the following two sections.

\subsubsection{Building Component Results}

Results for the component compliance evaluation of the PNL site visits are presented in Table 4.9. They indicate relatively high levels of code compliance with "perfect" compliance scores observed for slab insulation and windows and doors. Comparing these results to those for the WSEO sample (Table 4.4) indicates that the PNL sites had scores that were similar to the WSEO sites (between 1 and 2). All of the PNL site inspections were conducted on the east side of the Cascades. A comparison of the PNL results with similar data from the WSEO inspections east of the Cascades (Table 4.7) indicates the PNL sites generally had better compliance than the broader sample, al though the "scores" had similar distributions across components. For example, windows and doors were closer to full compliance than ducts in both samples. Comparisons based on energy code history (Table 4.10) produce similar conclusions. Although there are differences between the two samples, these could be explained by a variety of factors including the relatively small size of the PNL sample compared to the WSEO sample and the later 
IABLE 4.9. Average Component Compliance Rating for Sites Inspected by PNL

\begin{tabular}{||l|c|c||}
\hline \multicolumn{1}{|c|}{ Component } & TOTAL Average Compliance & TOTAL \# of Sites \\
\hline \hline Slab & 1.00 & 3 \\
\hline Floor & 1.26 & 19 \\
\hline Wall & 1.19 & 16 \\
\hline Ceiling & 1.31 & 16 \\
\hline Windows & 1.00 & 21 \\
\hline Doors & 1.00 & 21 \\
\hline Duct & 1.63 & 19 \\
\hline \hline Total \# of Sites Inspected & 21 \\
\hline Total \# of Jurisdictions Inspected & 5 \\
\hline
\end{tabular}

TABLE 4.10. Average Component Compliance Rating Categorized by Energy Code History for Sites Inspected by PNL

\begin{tabular}{||l|c|c|c|c||}
\hline \multirow{2}{*}{ Component } & \multicolumn{2}{|c|}{ PATH A } & \multicolumn{2}{c|}{ PATH B } \\
\cline { 2 - 5 } Compliance & $\begin{array}{c}\text { Number } \\
\text { of Sites }\end{array}$ & $\begin{array}{c}\text { Average } \\
\text { Compliance }\end{array}$ & $\begin{array}{c}\text { Number } \\
\text { of Sites }\end{array}$ \\
\hline \hline Slab & 1.00 & 3 & NA & 0 \\
\hline Floor & 1.15 & 13 & 1.50 & 6 \\
\hline Wall & 1.25 & 12 & 1.00 & 4 \\
\hline Ceiling & 1.17 & 12 & 1.75 & 4 \\
\hline Windows & 1.00 & 14 & 1.00 & 7 \\
\hline Doors & 1.00 & 14 & 1.00 & 7 \\
\hline Duct & 1.23 & 13 & 2.50 & 6 \\
\hline \hline $\begin{array}{l}\text { Total \# of Sites } \\
\text { Inspected }\end{array}$ & 14 & & 7 \\
\hline $\begin{array}{l}\text { Total \# of Jurisdictions } \\
\text { Inspected }\end{array}$ & 4 & & 1 \\
\hline \hline $\begin{array}{l}\text { PATH A = Former SGC participant } \\
\text { PATH B = Former SGC and NWEC participant }\end{array}$ \\
\hline
\end{tabular}


construction of homes in the PNL sample compared to those in the WSEO sample. Table 4.11 compares compliance ratings based on building activity level.

TABLE 4.11. Average Component Compliance Rating Categorized by Building Activity for Sites Inspected by PNL

\begin{tabular}{|c|c|c|c|c|c|c|}
\hline \multirow[b]{2}{*}{ Component } & \multicolumn{2}{|c|}{$\mathrm{HIGH}$} & \multicolumn{2}{|l|}{ MOD } & \multicolumn{2}{|l|}{ LOW } \\
\hline & $\begin{array}{c}\text { Average } \\
\text { Compliance } \\
\end{array}$ & $\begin{array}{l}\# \text { of } \\
\text { Sites }\end{array}$ & $\begin{array}{c}\text { Average } \\
\text { Compliance } \\
\end{array}$ & $\begin{array}{l}\# \text { of } \\
\text { Sites }\end{array}$ & $\begin{array}{c}\text { Average } \\
\text { Compliance } \\
\end{array}$ & $\begin{array}{l}\# \text { of } \\
\text { Sites } \\
\end{array}$ \\
\hline Slab & NA & 0 & 1.00 & 3 & NA & 0 \\
\hline Floor & 1.60 & 5 & 1.22 & 9 & 1.00 & 5 \\
\hline Wall & 1.00 & 3 & 1.33 & 9 & 1.00 & 4 \\
\hline Ceiling & 2.00 & 3 & 1.22 & 9 & 1.00 & 4 \\
\hline Windows & 1.00 & 6 & 1.00 & 9 & 1.00 & 6 \\
\hline Doors & 1.00 & 6 & 1.00 & 9 & 1.00 & 6 \\
\hline Duct & 2.80 & 5 & 1.22 & 9 & 1.20 & 5 \\
\hline \multicolumn{2}{|c|}{$\begin{array}{l}\text { Total \# of Sites } \\
\text { Inspected }\end{array}$} & 6 & & 9 & & 6 \\
\hline \multicolumn{2}{|c|}{$\begin{array}{l}\text { Total \# of Jurisdictions } \\
\text { Inspected }\end{array}$} & 1 & & 2 & & 3 \\
\hline $\begin{array}{l}\text { HIGH = } \\
\text { MOD = } \\
\text { LOW = }\end{array}$ & \multicolumn{6}{|c|}{$\begin{array}{l}\text { High building activity - } 50 \text { or more single-family } \\
\text { electrically heated housing starts per year. } \\
\text { Moderate building activity - } 5 \text { or more single-family } \\
\text { electrically heated housing starts per year. } \\
\text { Low building activity - Less than } 5 \text { single-family } \\
\text { electrically heated housing starts per year. }\end{array}$} \\
\hline
\end{tabular}

\subsubsection{Thermal Performance Simulation Results}

Comparisons of the PNL and WSEO samples based on relative thermal performance results are the most reliable, as the component "scores" are both non-linear and not weighted across components for energy impacts. The thermal characteristics of the PNL sample are presented in Table 4.12. Comparing these results to those for the WSEO sample (Table 4.8) indicates identical results for "TOTAL", "PATH B", "HIGH", and "EAST" compliance. Thermal 
performance scores for the other categories varied by only $1 \%$. These results lead to a conclusion that there is no serious sources of bias between the two samples.

TABLE 4.12. Average Percent Code Compliance Based on Prototype Overall UA Values for Sites Inspected by PNL

\begin{tabular}{||l|l|l|l|c||}
\hline \multicolumn{1}{|c|}{ Classification } & $\begin{array}{c}\text { Small } \\
\text { UA }\end{array}$ & $\begin{array}{c}\text { Medium } \\
\text { UA }\end{array}$ & $\begin{array}{c}\text { Large } \\
\text { UA }\end{array}$ & $\begin{array}{c}\text { Average } \\
\text { Compliance }\end{array}$ \\
\hline \hline TOTAL & 323 & 403 & 494 & $97 \%$ \\
\hline PATH A (SGC to WSEC) & 321 & 401 & 487 & $98 \%$ \\
\hline PATH B (SGC to NWEC to WSEC) & 326 & 406 & 508 & $96 \%$ \\
\hline HIGH Building Activity & 329 & 408 & 512 & $95 \%$ \\
\hline MODERATE Building Activity & 326 & 406 & 489 & $97 \%$ \\
\hline LOW Building Activity & 312 & 392 & 483 & $100 \%$ \\
\hline \hline
\end{tabular}




\subsection{WASHINGTON STATE ENERGY CODE PROGRAM PROCESS EVALUATION}

This element of the program evaluation addresses processes and activities that comprise the WSECP. This portion of the evaluation is processoriented, i.e., "it is an analysis of the process whereby a program produces the results it does" (Patton 1987, p. 23), and it is a formative evaluation, i.e., it is being "conducted for the purpose of improving [the program]" (Patton 1987, p. 28).

This chapter presents background information, an overview of the process evaluation purpose and limitations, an overview of the evaluation method, and a summary of the findings. Resulting recommendations are presented in Chapter 6.

\subsection{INTRODUCTION AND BACKGROUND}

This section presents information on the purpose of the WSECP and a review of findings from related prior studies.

\subsubsection{Program Purpose}

The overall purpose of the WSECP is

"to provide local code enforcement personnel with the training and support necessary to ensure that the 1991 Washington State Energy Code for electrically heated residential buildings is successfully implemented and enforced." (WSEO 1990, p. 1)

This process evaluation reflects the stated Program purpose, but examines code implementation steps in addition to code enforcement. This broader assessment is intended to inform WSECP administrators and participants more generally about how the code and Program are working and what improvements should be made.

Code implementation involves a number of steps. First, code officials must gain an adequate understanding of the code to incorporate it in their compliance checking process. Second, builders must gain an adequate understanding of the code to ensure that they design and know how to build new houses in accordance with the code. Third, builders must actually construct their buildings to comply with the code requirements. Finally, code officials 
must verify that new buildings comply with the code and that any deviations are corrected. This process evaluation considers the WSECP in the context of these code implementation steps.

\subsubsection{Prior Studies}

One step to provide background information in our study was to review the Washington State Energy Code Enforcement Study (WSBCC 1991), a study that was conducted on the Washington energy code in place before the new code. This study was sponsored by the Washington State Building Code Council (WSBCC).

The Washington State Energy Code Enforcement Study (WSBCC 1991) reported code official attitudes and preferences with regard to the Washington code in effect prior to implementation of the WSEC. The study found that a significant number of the code officials were not fully enforcing the energy code due to a lack of knowledge, training, or motivation, and that this lack of knowledge followed through to the building industry. The primary recommendation was to introduce a program to increase training and education of building department personnel, contractors, designers, and citizens on the reasons for and benefits of the energy code. The study recommended including implementation and inspection training. It also identified the need for funding to help support the training requirements and staffing needs associated with implementation and enforcement. Jurisdictional needs and the needs of the building community identified in this study helped shape the current WSECP.

In 1991, Bonneville contracted with PNL to conduct a progress evaluation of the WSECP. The Program progress evaluation(a) was conducted soon after the new WSEC went into effect. Because builders and code officials had only limited experience with the WSEC at that time, the evaluation findings focused on Program start-up activities and early expectations about Program impacts. For our purposes, that study provided a useful baseline and flagged key issues

(a) The evaluation was described in an unpublished report, "Progress Evaluation of the Washington State Energy Code Program," prepared for Bonneville by P. J. Barton and M. L. Carr of PNL. 
for tracking and reassessment in the current evaluation. The key findings of the progress evaluation included the following:

- Although most jurisdictions found the training good, some found it tedious or boring.

- Hotlines were being used but there were some delays, lack of clarity, and lack of authoritative interpretations.

- About half the Program jurisdictions said that builders did not understand the WSEC.

- The coexistence of the NWEC and WSEC for an extended period was anticipated to cause problems.

- Conditions for success appeared to be related to 1) how aware jurisdictions were that the Program existed, 2) how well jurisdictions understood the WSEC and their ability to translate it into their enforcement process, 3) how willing and able inspectors were to enforce the WSEC, 4) whether builders were able to obtain required supplies and materials, and 5) whether effective cooperative arrangements existed among organizations responsible for the WSEC and Program.

This previous evaluation identified several actions and issues that merited further investigation:

- The Program should focus on training improvements more than participation increases.

- Several characteristics of the Program should be quantified including how many jurisdictions got their monetary payments, codebooks, and other WSEC materials on schedule, how many officials attended training sessions, and how many used the hotlines.

- The effect of previous energy code experience on successful implementation of the WSEC should be examined.

- The extent to which paperwork is a burden should be clarified.

- The effectiveness of informal/formal information exchanges by code officials (e.g., regional networks) should be assessed.

- The effectiveness of code official, builder, and supplier training should be assessed.

The information presented in our process evaluation addresses these issues and recommendations. 


\subsection{OVERVIEW AND PURPOSE OF PROCESS EVALUATION}

The primary goal of our process evaluation was to assess how effective the Program had been in providing local code enforcement personnel with the training and support necessary to ensure that the WSEC for electrically heated residential buildings was successfully implemented and enforced.

The primary objectives of our process evaluation included assessing whether all four implementation steps listed in Section 5.1.1 were occurring effectively and determining how the Program had influenced implementation effectiveness. Code officials, builders (contractors and subcontractors), and equipment and material suppliers are all instrumental in successful code implementation. Consistent with the WSECP focus, our first-hand data collection was limited to code officials. Although this focus on code officials was consistent with the WSECP purpose statement, we wanted to include at least a limited assessment of Program impacts on builders and suppliers as well. To do this, we collected data from code officials on their perceptions about builders' and suppliers' compliance with the code and how the Program affected these groups.

The following objectives were also included for this evaluation to achieve the study's overall evaluation goal:

- Assess changes in the effectiveness of the Program when compared with findings presented in the initial process evaluation.

- Identify factors outside the Program that influenced WSEC implementation success and distinguish their effect from the effect of the WSECP.

- Clearly define the key Program components and assess the effectiveness of each.

This process evaluation is primarily an assessment of Program and Program component effectiveness. As discussed later, the fact that almost all jurisdictions in Washington, even those not participating formally in the Program, received WSEC training and technical assistance made it impossible to measure the effects of these two Program components on WSEC implementation. The evaluation findings, therefore, were based primarily on perceptions about how well each of the Program components was working. The evaluation relied 
largely on reported opinions and assessments of principal stakeholders, rather than objective measures of Program success.

The findings should be useful to Program designers and implementers interested in assessing and improving the Program. The large sample was carefully selected to give representative information about experiences with the Program and WSEC. (a) Information collected for the evaluation allowed identifying the effects of a range of factors. The approach was designed to highlight what has worked and has not worked in the Program. Furthermore, data collection and analysis allowed us to pinpoint links between Program characteristics and conditions needed for successful code implementation and enforcement.

\subsection{EVALUATION METHODOLOGY}

The analysis approach and methodology used in this process evaluation were designed to meet the goal and objectives described in Section 5.2. The following sections describe the various steps that we applied.

\subsubsection{Sample Selection}

Although representatives from local jurisdictions enforcing the WSEC were the key respondents providing information for this evaluation, representatives from other key organizations involved in the code and Program were also important contributors. We interviewed the following additional key Program contributors:

- Bonneville program manager, headquarters

- Bonneville area office cognizant program personnel

- WSEO program manager.

- Information from these contributors was collected through interviews with both open-ended and closed-ended questions.

(a) Nearly one-fourth of all jurisdictions with one or more housing starts in 1991 were included, representing about $54 \%$ of all housing starts in that year. 
The principal information for this evaluation was collected through telephone interviews with a sample of code officials from 46 jurisdictions across Washington. During the sample selection process, we obtained information on the following characteristics of the jurisdictions:

- number of single-family housing starts

- geographic location

- past participation in the NWECP.

To draw the sample it was necessary to have a complete list of Washington jurisdictions plus the above information. A list of all Washington jurisdictions, including information on jurisdiction contacts and telephone numbers, was obtained from WSEO. PNL compiled the information into one database for sample selection purposes (excluding those jurisdictions with no single-family housing starts).

Because a jurisdiction's prior energy code experience could affect the successful adoption and enforcement of a new energy code, jurisdictions were segmented into four categories according to whether or not they 1) were participating in the WSECP and 2) had participated in the NWEC. The resulting four groups of jurisdictions in the sample frame are shown in Table 5.1.

TABLE 5.1. WSECP Participant and Non-Participant Jurisdiction Sample Frame Groups

\begin{tabular}{||l|l||}
\hline \multicolumn{2}{|c||}{ WSECP Participants } \\
\hline $\begin{array}{c}\text { Group } A \\
n=96\end{array}$ & $\begin{array}{l}\text { Jurisdictions that participated in the WSECP but had not } \\
\text { participated in the NWEC }\end{array}$ \\
\hline $\begin{array}{c}\text { Group } B \\
n=43\end{array}$ & $\begin{array}{l}\text { Jurisdictions that participated in the WSECP and had } \\
\text { participated in the NWEC }\end{array}$ \\
\hline \multicolumn{1}{|c||}{ WSECP Non-Participants } \\
\hline $\begin{array}{c}\text { Group } C \\
n=28\end{array}$ & $\begin{array}{l}\text { Jurisdictions that had not participated in the WSECP but had } \\
\text { participated in the NWEC }\end{array}$ \\
\hline $\begin{array}{c}\text { Group } D \\
n=40\end{array}$ & $\begin{array}{l}\text { Jurisdictions that had not participated in the WSECP and had } \\
\text { not participated in the NWEC }\end{array}$ \\
\hline
\end{tabular}


Our sampling goal was to select as large a representative sample of jurisdictions as we could within the budget constraint. After assigning jurisdictions to one of the four groups according to their code and program experience, we broke each group into four strata based on 1991 housing starts in the jurisdiction. (a) A proportional sample of jurisdictions was then selected randomly from each of these sub-groups. ${ }^{(b)}$ Budget constraints 1 imited the number of jurisdictions interviewed to 46 . To allow for attrition, 85 jurisdictions were randomly selected from the PNL database and interviews were conducted with them until the targeted number in each group was reached. ${ }^{(c)}$ The 46 building jurisdictions selected represented over $22 \%$ of the 207 Washington jurisdictions with non-zero 1991 single-family housing starts. These jurisdictions also represented nearly 54\% of total 1991 single-

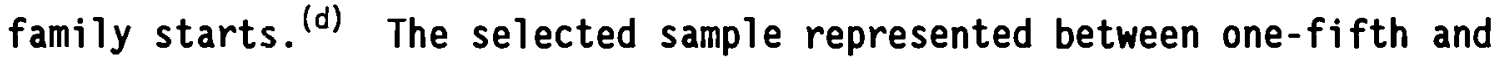
one-third of each of the four jurisdiction groups shown in Table 5.1. (e) See Appendix $G$ for detailed information on participating jurisdictions.

This sample captured representative variations in factors such as geographic area, past energy code experience, and number of housing starts. Table 5.2 shows the distribution of the jurisdictions in the sample frame and

(a) The housing starts data were for all housing starts, without taking into account heating fuel, so they did not necessarily correspond accurately to the distribution of electrically heated housing starts.

(b) In some sub-groups, the number of jurisdictions to select from was small. We rounded up the required sample size where necessary to ensure that each sub-group was represented in our sample.

(c) Code officials from only two of the selected jurisdictions declined to be interviewed so non-response did not introduce significant bias in the results.

(d) Only jurisdictions with code enforcement responsibility were interviewed for this study. We had no data indicating how many of the 207 jurisdictions had code enforcement responsibility.

(e) This sampling approach was modified in one way. The original pool of jurisdictions included none in group $D$ because the WSEO database we started with had limited information on this group and these jurisdictions had no familiarity with the WSEC Program or the NWEC. To establish a partial control group, a decision was made after the initial sample selection process to include some group $D$ jurisdictions in our sample. Because of the difficulty and associated cost of enlisting participation of these jurisdictions, only about $12 \%$ of group $D$ members were interviewed and, therefore, this group was underrepresented in our sample. 
IABLE 5.2. Distribution of Jurisdictions by Bonneville Area Office and Study Group, Number in Group, and Number Interviewed

\begin{tabular}{|c|c|c|c|c|c|c|c|c|c|c|}
\hline \multirow[b]{2}{*}{ Group } & \multicolumn{2}{|r|}{ All areas } & \multicolumn{2}{|r|}{ PSA } & \multicolumn{2}{|r|}{ UCA } & \multicolumn{2}{|r|}{ SRA } & \multicolumn{2}{|r|}{ LCA } \\
\hline & Total & $\begin{array}{l}\text { \# interviewed, } \\
\% \text { of total }\end{array}$ & Total & $\begin{array}{l}\text { \# interviewed, } \\
\% \text { of total }\end{array}$ & Total & $\begin{array}{l}\text { \# interviewed, } \\
\% \text { of total }\end{array}$ & Total & $\begin{array}{l}\text { \# Intenviewed, } \\
\% \text { of total }\end{array}$ & Total & $\begin{array}{l}\text { \# intervlewed, } \\
\% \text { of total }\end{array}$ \\
\hline A & 96 & $23,24 \%$ & 50 & $11,22 \%$ & 25 & $6,24 \%$ & 14 & $4,29 \%$ & 7 & $2,29 \%$ \\
\hline B & 43 & $11,25 \%$ & 20 & $3,15 \%$ & 14 & $5,36 \%$ & 5 & $2,40 \%$ & 4 & $1,25 \%$ \\
\hline $\mathrm{C}$ & 28 & $7,25 \%$ & 17 & $4,24 \%$ & 9 & $3,33 \%$ & 1 & $0,0 \%$ & 1 & $0,0 \%$ \\
\hline D & 40 & $5,12 \%$ & 21 & $2,10 \%$ & 12 & $1,8 \%$ & 4 & $2,50 \%$ & 3 & $0,0 \%$ \\
\hline Totals & 207 & $46,22 \%$ & 108 & $20,19 \%$ & 60 & $15,25 \%$ & 24 & $8,33 \%$ & 15 & $3,20 \%$ \\
\hline \multicolumn{11}{|c|}{$\begin{array}{l}\text { Note: "Total" Indicates the actual number of jurisdictions in the category } \\
\text { PSA = Puget Sound Area } \\
\text { UCA = Upper Columbia Area } \\
\text { SRA = Snake River Area } \\
\text { LCA = Lower Columbia Area }\end{array}$} \\
\hline
\end{tabular}


our final sample by code group and Bonneville area office. The Bonneville area offices serving the jurisdictions are Puget Sound Area (PSA), Lower Columbia Area (LCA), Snake River Area (SRA), and Upper Columbia Area (UCA).

\subsubsection{Data Collection}

Telephone interviews of local code officials were the principal data collection method used in this evaluation. Two primary survey instruments were developed: the first was for jurisdictions that currently participate in the WSECP, and the second was for jurisdictions that do not currently participate in the Program. Both instruments contained closed-and open-ended questions. The questionnaires differed slightly for these two groups; however, each survey instrument was applicable to jurisdictions with and without past NWEC experience. Samples of the questionnaires are presented in Appendix $H$.

Draft survey instruments were prepared and provided to the Bonneville program and evaluation project managers for review. Representatives from the Association of Washington Cities (AWC) and the Washington Association of Building Officials (WABO) were contacted about the evaluation and informed that we would be contacting their constituents. Both organizations reviewed and approved the draft survey instrument.

After comments on the draft were received and appropriate revisions were made, pre-test phone interviews were conducted with three jurisdictions. Based on the pre-tests, slight modifications were made to the instruments.

The data collection process for jurisdictions involved an initial phone call to identify the appropriate respondent and arrange a time for the interview. (a) A copy of the questionnaire was then faxed to the respondent to facilitate the interview process. Most respondents were able to review the questions prior to the interview, which expedited the process. Interview duration times ranged from 35 minutes to 1 hour 15 minutes, with the average around 50 minutes. ${ }^{(b)}$ We were unable to complete interviews with only a few

(a) The length of the interview depended in part on whether or not the jurisdiction had participated in the NWEC.

(b) Code officials interviewed were either the primary contact person identified by WSEO or the individual identified by the jurisdiction as having the most relevant experience and knowledge. In some cases, 
jurisdictions. The most common reason was because the jurisdiction's energy code enforcement was performed by some other jurisdiction (usually the county). In two cases the code official did not have the time available.

Once the telephone interview was complete, the information was entered into a word processing form and later transferred to askSam, a text database and analysis software package. This package facilitated analysis of the text data through key word searches, tallies of responses, and output of word processing-compatible files.

\subsubsection{Data Analysis}

Interview data were used to analyze the effectiveness of specific Program components, effects of other factors (such as building activity level), and overall Program effectiveness. Many of the data were associated with responses to specific interview questions. We identified these questions, reviewed all the responses to them, and then analyzed them in terms of how they were affected by Program participation, NWEC experience, and other key factors. Other data were generated by searching our database for key words associated with the issues of interest.

Virtually all jurisdictions had participated in WSEC training and technical assistance whether or not the jurisdictions were formally participating in the Program. Consequently, it was not possible to compare the experiences of jurisdictions that had received WSEC training and technical assistance with those that had not, and to use the comparison to measure the effects of training and technical assistance on implementation. In addition, direct measures of code enforcement and implementation success were difficult to identify. As a result, this process evaluation relied almost exclusively on the opinions and experiences of interviewees, rather than objective measures, to determine how effective each Program component and the overall Program had been.

interviewees discussed the interview topics with other knowledgeable jurisdiction staff to obtain supplemental information prior to the phone interview. 
Because the primary purpose of this analysis was to evaluate the impact of the WSECP, we needed to separate out the impacts of other factors such as prior energy code experience, utility support, and local government support. Our data analysis examined the relationship between these factors and code and Program experiences. This provided a basis for understanding the effects of these factors and helped prevent their effects from being incorrectly attributed to the Program.

The most influential non-Program factor was previous experience with the NWEC. Data collection confirmed prior expectations that jurisdiction experience with prior energy-efficiency code programs, in particular the NWEC, would have a significant effect on implementation of the WSEC. In our analysis, therefore, we controlled for the effect of NWEC participation when we assessed the impacts of the WSECP. To control for this effect, we compared the responses of jurisdictions that were NWEC participants and did participate in the WSECP (group B) with those that did not participate in the WSECP (group C). We made the same comparison for those jurisdictions that were not NWEC participants (groups $A$ and D). Figure 5.1 shows which groups were compared to control for the effects of participation in the NWEC.

\subsection{KEY PROCESS EVALUATION FINDINGS}

This section provides the key findings from this process evaluation. As noted earlier, certain factors outside the Program were expected to have significant effects on the implementation of the WSEC and effectiveness of the Program. The findings for these outside factors are presented first. These findings are followed by findings on the effectiveness of individual Program components, overall success of the Program in easing WSEC implementation, and remaining problem areas or issues that we were unable to adequately address, resolve, or assess. Appendix I presents supplemental findings and a more detailed discussion. 


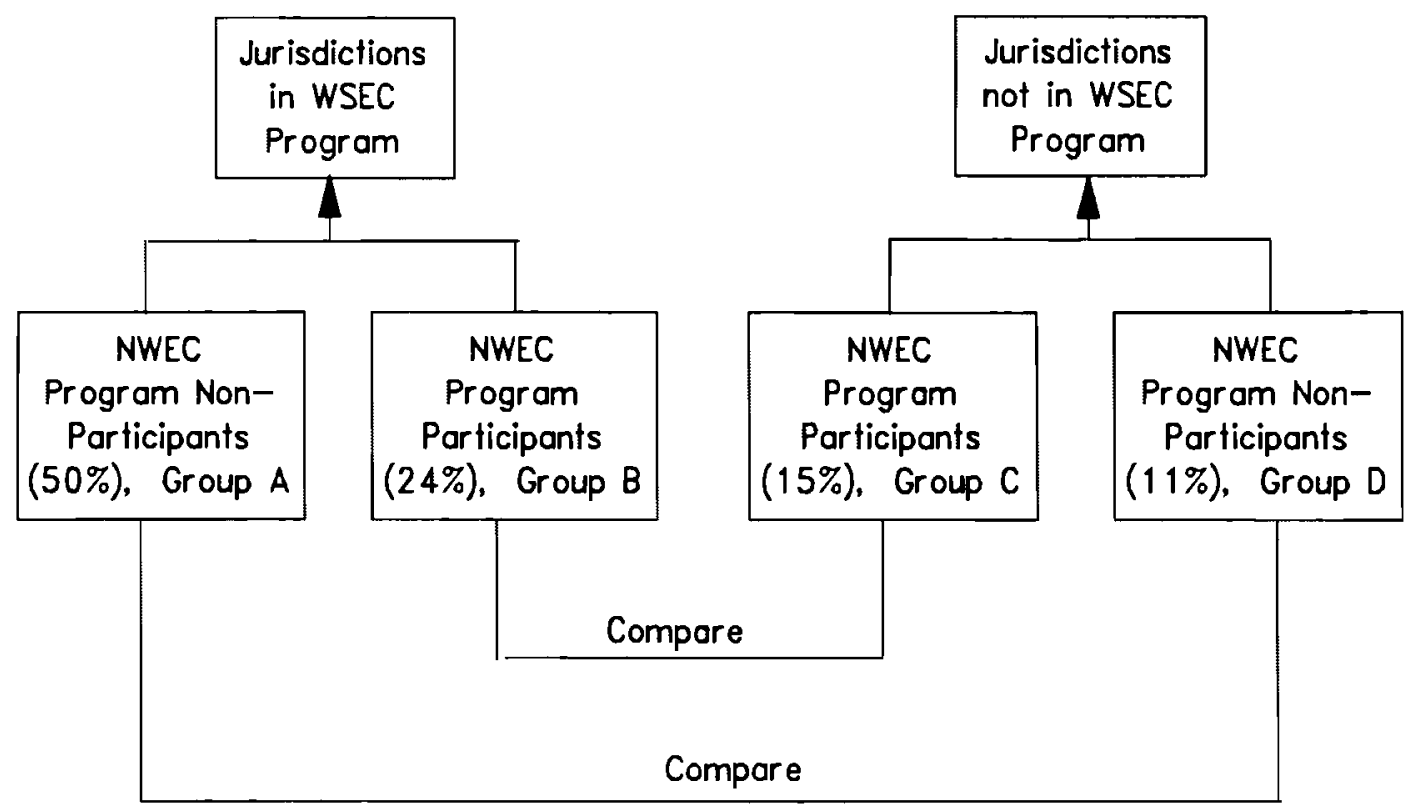

Note: Percentages refer to shares of the interviewees in each category.

FIGURE 5.1. Categories of Code Jurisdictions

\subsubsection{Influence of External Factors}

Several factors that were not directly tied to the Program were expected to or were revealed to have a significant influence on WSEC implementation success or Program effectiveness. Our findings regarding the influence of prior energy code experience, utility support, local government support, code official networks, and the level of building activity follow.

Prior Energy Code Experience

PNL's earlier progress evaluation suggested that the effect of previous energy code experience on WSEC implementation should be examined. The available data did not allow us to assess the effect of Super Good Cents Program 
experience but did permit us to make the following assessments of the influence of NWEC experience on WSEC implementation success and responses to the WSECP:

- Prior experience with the NWEC was associated with significantly improved builder understanding of the WSEC: in Program jurisdictions with prior NWEC experience, code officials reported that $70 \%$ of the builders had a good understanding of the WSEC, whereas only $20 \%$ were reported to have a good understanding in jurisdictions without prior NWEC experience.

- Prior experience with the NWEC also was linked to significantly improved builder attitudes toward the HSEC: in Program jurisdictions with prior NWEC experience, code officials reported that $30 \%$ of the builders had a good response to the WSEC, whereas only 5\% were reported to have a good response in jurisdictions without prior NWEC experience.

- Prior NWEC experience, however, did not affect the frequency of recurring builder compliance problems or the types of compliance problems.

- Prior experience with the NWEC helped jurisdictions implement the HSEC: $80 \%$ of the Program jurisdictions reported that prior NWEC experience had helped them implement the WSEC. Prior NWEC experience also significantly increased the proportion of code officials in Program jurisdictions reporting that they had received sufficient training and support. Ninety-one percent in prior NWEC jurisdictions reported they had received sufficient training and support compared with $76 \%$ in jurisdictions without NWEC experience.

- Participation in the Program appeared to be effective in reducing confusion between the WSEC and NWEC: although code officials in $71 \%$ of non-Program jurisdictions that had enforced the NWEC previously reported confusion between the two codes, only $10 \%$ of the respondents in Program jurisdictions reported similar problems.

Because of the significant effects of NWEC experience, all findings about the effects of the WSECP presented later were assessed, using the approach 17 lustrated in Figure 5.1, to ensure that the NWEC effects were accounted for.

\section{Utility Support}

Utilities in the Pacific Northwest have played an important role in the implementation of residential energy codes and programs. Utility support in the form of training, technical assistance, code interpretations, WATTSUN 
program assistance, and inspections of homes was available to some Washington jurisdictions. As part of this evaluation, code officials were asked how important they thought utility support was for successful energy code implementation, if they received utility support, what type of support they received, and whether or not this support had a positive impact on successful WSEC code implementation and enforcement in their jurisdiction. Evaluation findings about the effect of utility support on WSEC implementation were as follows:

- Our data suggested that only about half the jurisdictions had received some utility support with the HSEC.

- Jurisdictions receiving utility support rated it as very important to successful WSEC implementation: jurisdictions that had received utility support gave it an average importance rating of 4 on a scale from 1 to 5 . Receiving jurisdictions were generally very pleased with the support. Training, technical assistance, and WATTSUN assistance were the most common forms of support.

- Jurisdictions not receiving utility support rated it as less important to successful WSEC implementation: jurisdictions that had not received utility support gave it an average importance rating of 3.1 on a scale from 1 to 5 . Some jurisdictions not receiving utility support had misgivings about the potential for the utility to have a different agenda or perspective than the jurisdiction.

\section{Local Government Support}

It seemed likely that the degree of support provided by local governments to their code enforcement officials could affect how successfully an energy code was implemented. Our findings confirmed this expectation.

- Code officials rated local government support as one of the most important factors in successful energy code implementation: on the average, jurisdictions gave local government support an importance rating of 4.1 on a scale from 1 to 5 . The two major advantages of government support were resource allocations and credibility.

\section{Code Official Networks}

Networks of code officials provide a forum for discussing and sharing information on energy codes. This information exchange, or networking, can be done formally through meetings with established peer organizations such as the AWC and the International Conference of Building Officials (ICBO), and other 
formalized peer groups, or informally via periodic (and often impromptu) meetings with other local code officials. Routine phone calls between code officials which may cover energy code issues on occasion are not considered "networking" for the purposes of this study. In our earlier study (1991) PNL suggested that the effectiveness of formal and informal networks be assessed. Code officials in our study indicated that most have availed themselves of either formal or informal networks during implementation of the WSEC. Our major findings were the following:

- Participation in formal networks was high and the networks were rated as highly effective: half the jurisdictions surveyed had participated in formal networks sponsored by a range of organizations. Nearly $70 \%$ of these jurisdictions rated these networks as quite effective.

- Participation in informal networks was less, but they were also rated as highly effective: 17\% of surveyed jurisdictions participated in informal networks and they all rated these groups as very effective.

- The jurisdictions not participating in networks had various reasons for not doing so: al though most jurisdictions not participating in networks believed that they would be beneficial, several stated that they had not joined because participation would impose added time and staff demands, or that the meetings were not held at convenient times or locations.

\section{Building Activity Level}

Arguments have been made that building activity level could affect the success of implementing the WSEC in different jurisdictions. Possible relationships between activity level and implementation success are manifold and possibly contrary. For example, higher activity levels might mean that builders learn lessons faster and are less likely to forget what they had learned on previous jobs. On the other hand, higher activity levels might stress the building department's resources, preventing code officials from doing very thorough inspections and field training. Of course, the effects of the building activity level on the code officials would depend in part on the resources committed to code implementation and enforcement. For all these reasons, it was very difficult to determine a simple relationship between activity level and WSEC implementation. 
To address the effect of activity level, we took two steps. One was to ask code officials how important they thought building activity level was in determining the success of implementing an energy code. The answers helped assess whether activity level was an important factor. The second step was to examine key findings further to determine whether they were correlated with the jurisdiction's building activity level.

Mostly in the interest of avoiding incorrectly attributing to the Program effects that were caused by building activity level, we assessed the relationship between building activity level (in terms of annual housing starts) and code implementation. The findings included these:

- Activity level was not considered to be among the most important factors in code implementation success: on the average, activity level was perceived by code officials to be moderately important in determining code implementation success. No major differences were apparent across groups of jurisdictions.

- The effects of building activity level on WSEC implementation effectiveness were ambiguous: in jurisdictions where activity level was considered an important factor, some indicated that high levels would facilitate implementation (because of increased learning and information sharing among builders) and others indicated that low levels would facilitate implementation (because of reduced administrative burdens).

- High building activity level jurisdictions had specific reservations about the WSEC: these jurisdictions were the most likely to express reservations about the justification for the WSEC and how it had shifted resources away from enforcement issues considered to be more important (e.g., safety).

- Low building activity level (usually smaller) jurisdictions were often overburdened: several were having major problems implementing the WSEC and were reluctant to join the Program because they saw it as imposing additional burdens on the jurisdiction without sufficient benefits.

\subsubsection{Effectiveness of Program Components}

The primary components of the Program were funding, start-up support and training, on-going training and support, and technical assistance. The following sections discuss how well the various components of the Program were performing. Most of these components involved the code officials, but where they involved others, such as builders, these results are discussed. We also 
include a discussion of institutional relationships that affected Program success.

\section{Funding and Payments}

One of the main advantages to jurisdictions participating in the Program were start-up payments and funding to attend training. Builders also received payments, but they were associated with the WSEC, not just the Program.

Principal findings about these two payments were as follows:

- Start-up payments and training funding mechanisms appeared to be working well: contrary to some early concerns, nearly all code enforcement departments were receiving Program funding without any problems.

- Code officials questioned the benefits of the builder payments: only one-fourth of Program jurisdictions felt that builder payments were important for successful WSEC implementation; none of the nonProgram jurisdictions felt they were important. Several officials questioned the fairness of paying builders to comply with the law.

\section{Start-Up Support}

The Program provided initial start-up support to jurisdictions, which included activities such as helping jurisdictions set up their computer system (if applicable), answering questions regarding the Program paperwork, and answering specific questions about the WSEC. This support was generally available to jurisdictions as part of the Program start-up package. Major evaluation findings on the start-up support were as follows:

- Start-up support appeared to be reaching jurisdictions successfully: 91\% of Program jurisdictions reported receiving Program start-up training and support. Seventy-five percent of those jurisdictions receiving start-up support had received assistance in both the field and office.

- The start-up support received high marks: over $90 \%$ of the jurisdictions receiving start-up support said that it was very helpful. Code officials often commented that the support was critical to getting them up and running with the code and familiarizing them with the administrative requirements.

On-Going Training

Training was one of the cornerstones of the Program. The Program offered code officials a menu of different training workshops including code 
overview, plan review, site inspection, component performance, and ventilation. Builders and suppliers were also typically welcome at these training sessions.

PNL found that in the early stages of the Program most participants felt that the training was good, but some found it tedious. In an earlier evaluation, PNL recommended assessing the effectiveness of the code official, builder, and supplier training. We also recommended that more emphasis be placed on improving the training in lieu of increasing Program participation. our current findings on the training component are as follows:

- The priority given to training has been increased: WSEO reported that, in response to early program evaluations, efforts had been shifted away from trying to increase Program participation toward improving the training. WSEO also indicated that code official training had been changed to be less academic and to respond more to local needs.

- Jurisdiction participation in WSEC training, even for jurisdictions not in the Program, was almost universal: code officials from virtually all jurisdictions had received Program training provided by the state; only one respondent indicated that he had attended no training. Because of this, it was not possible to evaluate the impact of the training by comparing WSEC implementation between groups receiving and not receiving training.

- Overal1, the training received high marks: about 90\% of code officials rated the training as "good" to "excellent."

- Despite the high marks for the training activity, a significant subset of code officials felt that something more was needed to prepare them for enforcement: nearly 20\% expressed concerns that they needed more preparation for enforcement of the WSEC. Criticisms of the training included the need for coverage of more complex issues, inclusion of different skill levels, and more convenient scheduling and locations.

- Insufficient builder training was considered to be a serious prob1em: builder attendance at training sessions had been poor. Training of one-time builders was a special concern to several code officials. Lack of builder training had a number of ramifications including a lack of builder understanding of the code (consistent with our earlier findings), recurring compliance problems, and burdens being placed on code officials to frequently provide de facto builder training in the field. It appeared that builders had determined that it was less costly to them to learn the code 
through trial and error than to take the time to attend training sessions.

- Minimal supplier training had occurred, but this was not perceived to be a problem: although training was available to suppliers, almost no suppliers had attended.

\section{Technical Assistance and Hotlines}

Technical assistance was the other cornerstone of the Program. Technical assistance differed from training in that it was typically individualized support provided through a technical assistance hotline managed by the state or through other means. Because technical assistance, like training, was available to code officials in all Washington jurisdictions, jurisdictions both participating and not participating in the Program were asked if they had received technical assistance from the state and if the assistance received was useful. The earlier PNL study found some problems with the technical assistance hotlines, a primary part of the technical assistance service. Key findings from our current study on technical assistance and the hotlines were as follows:

- WSEO reported technical assistance and hotline improvements: WSEO reported that steps had been taken to reduce inconsistencies in answers to technical questions, and that technical difficulties with the hotlines had been remedied.

- Jurisdiction receipt of technical assistance, even for jurisdictions not in the Program, was almost universal: as with training, code officials from virtually all jurisdictions had received Program technical assistance provided by the state. Again, this fact meant that it was not possible to evaluate the impact of the technical assistance by comparing WSEC implementation between groups receiving and not receiving technical assistance.

- The technical assistance received high marks generally: about 85\% of code officials interviewed reported that the technical assistance had been useful.

- Technical assistance problems were the same as reported in the past: for those jurisdictions that were not satisfied with the technical assistance, the problems were reminiscent of those PNL 
found earlier--not being able to get through on the hotlines, low technical expertise of hotline operators, or the complexity of the code itself.

\section{Institutional Relationships}

We interviewed the Bonneville headquarters Program manager, participating Bonneville area office staff, and the WSEO Program Administrator to identify administrative and institutional issues that might have impacted implementation of the WSEC and conduct of the Program. Clarity of organizational roles and good cooperation among the participant organizations was felt to be a necessity in this Program. Our findings on these issues were as follows:

- The working relationship between WSEO and Bonneville had been very good.

- Some differences existed in perceptions about the role of Bonneville area offices: WSEO had a perception that Bonneville's area offices were not playing as large a role in the Program as was originally intended, but Bonneville staff disagreed. This was not a major obstacle in the Program, but it was a source of confusion and uncertainty.

- Industry groups should be involved even more: WSEO believed that industry groups that had been very involved in the Program had helped implementation, but that some groups (such as the Building Industry Association of Washington [BIAW]) should have been more involved.

- Utility involvement was not consistent: similar to code official observations, both Bonneville and WSEO noted that some utilities had provided excellent support to jurisdictions and builders, but that some utilities had provided none.

\subsubsection{Overall Program Success}

Our assessment of overall Program success addressed how well the four major steps in the implementation process were working: 1) code official awareness and understanding of the WSEC, 2) builder awareness and understanding of the WSEC, 3) builder construction to the WSEC, and 4) code official enforcement and verification of compliance with the WSEC. As noted earlier, the effect of the Program was difficult to evaluate because training and technical assistance, the two cornerstones of the Program, had been available to all jurisdictions and builders who wanted them. Our assessment 
provided an overall measure of how well the code was being implemented and identified effects of the Program to the extent possible. This section provides our key findings on overall Program effectiveness.

Code Official Awareness and Understanding

As noted in PNL's earlier evaluation, code official understanding of the WSEC was a major condition required for successful implementation. Code officials were required to explain the code to builders and check compliance throughout the review process. Our key findings were as follows:

- Code training and technical assistance, in general, was considered to be very important: code officials gave training and technical assistance programs, in general, an importance rating of 4.2 or higher, on a scale from 1 to 5 , for increasing understanding and easing implementation of an energy code.

- The Program received favorable marks for improving code official understanding of the WSEC: 93\% of Program participant jurisdictions indicated that the Program had been of some benefit in improving their understanding of the code, and about two-thirds said that it had provided large benefits.

- The Program was instrumental in reducing code official anxieties about the WSEC: 25\% of Program non-participants expressed concerns about the code being hard to justify or changing too often, whereas only $10 \%$ of Program participants expressed similar concerns.

- The Program was also instrumental in reducing code officials' perceptions that the WSEC would place excess burdens on them: while almost none of the Program participants expressed concerns that the WSEC placed an inequitable burden on them, half the Program non-participants did. Perceived burdens were reduced in part by the improved understanding Program participants had of the code.

- Some smaller jurisdictions anticipated that Program participation would place an unacceptable burden on them: several indicated that their understanding and awareness of the WSEC had been improved by available training and technical assistance, but they had chosen purposely to not join the Program officially because the Program paperwork would place excessive burdens on them.

\section{Builder Awareness and Understanding}

Builder awareness and understanding of an energy code is of paramount importance in effective implementation of a code. Although the inspection and 
enforcement process can, ideally, remedy noncompliance, the burden on code officials would be reduced and the likelihood of compliance would be increased if builders understood the code adequately to start with. As noted earlier, our assessment of builder understanding was based on code official perceptions. Our key findings about builder awareness and understanding were as follows:

- A significant proportion of all jurisdictions rated builder understanding of the WSEC as "poor": 25\% of builders were rated as having a "poor" understanding of the WSEC. This represented a significant improvement over the findings in PNL's earlier study. Overall, $40 \%$ of the officials rated builders' understanding as "good."

- Jurisdiction participation in the Program appeared to have no effect on builders' understanding of the WSEC.

- Jurisdiction experience with the NWEC was associated with improved builder understanding of the WSEC: $65 \%$ of officials in jurisdictions with NWEC experience rated builders' understanding of the WSEC as "good," whereas only $20 \%$ did so in jurisdictions without NWEC experience.

- As noted earlier, poor builder attendance at training sessions seemed to be a root cause of inadequate builder understanding of the WSEC.

\section{Construction to the code}

Even though they might have strived to, builders still might not have built to the code for a number of reasons. Our key findings about construction to the WSEC were as follows:

- Independent of Program participation or NWEC experience, most jurisdictions reported recurring compliance problems: about $80 \%$ of the jurisdictions reported recurring compliance problems.

- Noncompliance was usually associated with improper installation of insulation, caulking, and vapor barriers, and problems with exhaust fans and venting.

- Jurisdiction participation in the Program did not appear to affect the reasons for noncompliance: the most common reason for builder noncompliance was a lack of builder understanding of the WSEC. As noted earlier, jurisdictions that had participated in the NWEC, however, appeared to experience fewer problems attributable to lack of builder understanding of the WSEC. 
- Lack of subcontractor understanding of the USEC contributed to noncompliance: nearly $20 \%$ of the code officials believed that lack of subcontractor understanding of the WSEC was a common reason for noncompli ance.

- Unavailability of materials and equipment appeared to be a minor problem: some cases of noncompliance were caused by the unavailability of required materials and equipment early on; this problem appeared to have diminished considerably over time, however.

\section{Enforcement and Verification of Compliance}

The ultimate step in implementation of an energy code is verification that new buildings comply. Actual compliance measurement was beyond the scope of this process evaluation; however, information collected permitted a qualitative assessment of some aspects of enforcement and verification. Our key findings follow:

- Jurisdictions in the Program felt that the training and support aspects of the Program had been effective for enforcement: about $80 \%$ of the Program jurisdictions reported that the training and support aspects of the Program had been adequate. About 20\%, however, believed that the training had not been adequate: the WSEC was too complex, training had not been scheduled at convenient times and places, and an on-going training program was essential.

- Most jurisdictions had remaining frustrations and misgivings about being able to enforce the WSEC adequately: although most believed that the training had been adequate, two-thirds of the jurisdictions believed that more needed to be done to help them enforce the code. Desired changes included code revisions, additional administrative support, and training enhancements.

- Experience with the NWEC appeared to make code officials more confident that they could enforce the WSEC adequately: among Program participating jurisdictions, the percentage $(60 \%)$ of NWEC participants that felt they were adequately prepared to enforce the WSEC was three times the percentage of non-NWEC jurisdictions that felt they were adequately prepared.

\subsubsection{0ther Issues}

This process evaluation has provided important information about several aspects of the Program, but other aspects and issues remained that did not fit into the prior categories of findings. Some were related more directly to the WSEC itself than the Program. The key items in this category were the following: 
- Perceived complexity of the code appeared to be a common problem and this complexity increased the difficulties of enforcing it.

- Some jurisdictions felt that the state had placed an unfair burden on the local jurisdiction by imposing the USEC.

- Some jurisdictions believed that code revisions should be conducted on a cycle consistent with other building codes.

- It appeared that the consumer had been left out of the process: education of home buyers on the benefits of energy codes emerged in several interviews as a way to ease implementation and increase public support. 


\subsection{CONCLUSIONS AND RECOMMENDATIONS}

The primary objective of this evaluation was to determine the relative effectiveness of the Washington State Energy Code Program in achieving compliance with the Washington State Energy Code. Secondary objectives included determining relative satisfaction with the WSECP, identifying any systematic areas of weakness in the WSECP or compliance with the WSEC. The chapter presents our conclusions with respect to these objectives and subsequent recommendations. Our recommendations follow the discussion of our conclusions.

\subsection{THE ROLE OF THE WSECP IN COMPLIANCE WITH THE WSEC}

The results of the field data analyses project nearly complete compliance with the WSEC in WSECP jurisdictions (i.e., over 95\% achievement of energy savings from the code). Unfortunately, the role of the WSECP in that achievement is difficult to separate from numerous previous and concurrent programs to improve energy efficiency in residential construction through improved products, increased market demand, and better training of builders and materials dealers. Bonneville sponsored several efforts prior to the adoption of the WSEC to pave the way for passage of the WSEC as a State-wide energy code. Programs like Super Good Cents and the Northwest Energy Code activities included many of the same features as the WSECP and even relied on WSEO for support in some cases. It was expected at the outset of this evaluation that uneven participation in these programs by utilities and local jurisdictions would provide a means to test the hypothesis that prior experience with energy codes and standards would lead to better compliance with the WSEC. Although this evaluation did not compare compliance between participants and non-participants in the WSECP, participation by either utilities or jurisdictions in prior energy standard activities influenced construction practices in virtually all areas of the state.

It would be easy to conclude from this finding that the program is a success, has largely achieved its objectives, and could be discontinued. However, it would be a disservice to end this evaluation with that conclusion for several reasons: 
- Although high levels of compliance were observed, many issues were raised in our data gathering and interviews that indicate this current success may need ongoing support to maintain.

- Washington was the first of four states in the region to adopt the Northwest Energy Code as a State energy efficiency code. Oregon has since followed suit. Montana and Idaho have yet to implement similar codes state-wide. Results in these states, where Bonneville's customers serve a smaller fraction of the population, may be far different than in Washington. Lessons learned from this evaluation can point the way to issues that should be addressed in these states.

- The high level of compliance achieved with the WSEC offers encouragement to energy planners who would like to mandate energy efficiency but worry about compliance issues. However, some jurisdictions in Washington had up to 10 years of experience with energyefficiency codes. This created a favorable environment for energy efficient building, training, and codes. A more extensive discussion of our conclusions from this evaluation may better illuminate this issue.

\subsubsection{Main Conclusions}

The major conclusions reached in this evaluation are as follows:

- High compliance was observed in terms of energy savings achievements.

- Full compliance was not achieved on specific construction components, but these had little effect on energy savings.

- Compliance with code still leaves plenty of room for improvements in the quality of measure installation, which affects energy use.

- The "environment" for energy-efficient construction created prior to the adoption of the WSEC was likely a critical ingredient in current compliance levels. This "environment" needs to be maintained to convey the "value" associated with the WSEC to jurisdictions, code officials, builders, and home buyers.

- As expected, there were complaints about the code, but these complaints did not appear to translate into actions that undermined compliance. Moreover, individuals involved with the code expect further revisions to the code over time and suggested ways to make the revision process more efficient.

- Code officials complained of being overworked and see the energy code as an additional burden.

- Builder participation in code training classes was low. Moreover, the subcontractors who actually do most of the construction rarely 
participate in training. Code officials noted that the burden of training builders seems to have fallen to them.

- The role of Bonneville and the utilities in the WSECP is unclear.

\subsubsection{Themes}

This evaluation depended on two primary sources of information: field inspection records detailing levels of code compliance for each construction component and informal interviews with builders and code officials during field inspections, as well as structured interviews with code officials, Bonneville staff, and others with a role or interest in the WSEC. These interviews revealed an apparent conflict between the high levels of code compliance observed and the attitudes of the individuals involved in WSEC implementation. Individuals involved in code implementation voiced concerns about code compliance that do not appear to be supported by field data. To some extent, this may reflect the fact that without the kind of overview provided by this evaluation, these individuals have no way of determining if the WSEC is "working" and they may end up "projecting" their concerns. In fact, PNL received many requests for the results of this evaluation from interview subjects who want that kind of overview.

The conclusions listed above comprise three major "themes:"

- The institutional environment for codes is positive.

- Improvements in the code and in the code adoption process can and should be made.

- Energy efficiency still needs to be "sold."

These themes are discussed in the following sections.

Positive Institutional Environment. Implementing the WSEC in Washington was a contentious process. Bonneville has been working on strengthening energy efficiency codes since the NWPPC's $1983 \mathrm{Pl}$ an. In the intervening years they have tried to "prime" the market for energy-efficient buildings through programs with large incentives paid to jurisdictions (Early Adopter, NWEC), builders (Early Adopter, NWEC, Super Good Cents, WSECP), and utilities (Early Adopter, NWEC, Super Good Cents). These efforts were designed to reduce institutional resistance to the NWEC. Nevertheless, Bonneville was opposed by 
the representatives of the homebuilding and natural gas industries. (The Seattle Master Builders and regional gas companies sued Bonneville over this issue). Opposition to the WSEC by these interests delayed its full adoption until the 1990 Legislative session, despite the fact that the WSEC was proposed in earlier sessions; the WSEC was partially adopted in 1986.

This fractious history would suggest that deep-seated institutional resistance to the code would still exist and compliance may suffer as a result. In contrast to this expectation, the high level of compliance observed the first year after code adoption indicated a lack of deeply rooted opposition to energy efficiency codes. In fact, our interviews with code officials and informal comments from builders indicate both groups anticipate continuing revisions to the WSEC and both groups suggested ways to make future revisions easier to implement, despite pro forma objections to "burdensome regulations." This indicates that energy resource acquisition through codes and standards can be highly successful and may not be as politically costly as it appears. Room for Improvement in Construction. Comments from code officials, as well as field inspectors, indicate there is room for improvement in the way the code is implemented despite the high level of energy savings measures installed. This conclusion emerges from the "sense" expressed in interviews with code officials that there are continuing compliance problems and PNL's field observations of sloppy, but still compliant, installation of measures. Room for Improvement in the Code Process. Comments were also received about problems with both the process of code adoption and its actual implementation. Most of these related to concerns expressed by code officials about being overworked due, in part, to the way the code was adopted and some of its provisions. Both code officials and builders complained that the energy code was implemented "out-of-synch" with changes in overall building codes. Typically, building codes are revised on a 3-year cycle. Builders and code officials suggested linking future codes to these same cycles.

Code officials also complained about several aspects of the WSEC. They objected to the fact that they felt they were doing too much of the builder education on the job site. They felt it was incumbent on the builders to learn the code, not on inspectors to teach them. The second complaint was 
about the application of the WSEC to residential remodeling. The specific issue was that most residential remodels cannot comply with the WSEC yet they are expected to so. This issue was not a focus of this evaluation; however, the comments are worth mentioning for future code programs and are important in urban areas where remodeling accounts for a large fraction of residential building activity. The last major complaint was about the complexity of the WSEC. Two issues emerged in this regard: 1) the code was thought to be overly complicated in general and 2) the multi-path approach was specifically criticized as a cause. The comments about compliance paths centered on the fact that almost all of the construction is done under two of the three paths and the code could be revised to simplify enforcement under these two paths. Both builders and officials shared this perspective.

Code complexity is a near-universal complaint, so this comment is not surprising. What is of greater concern in these comments is that builder participation in code training was seen as low and that participation of the subcontractors who actually build the homes was rare.

Energy Efficiency Still Needs to be "Sold". Although compliance with the WSEC is good, code officials thought that there needs to be continuous reinforcement of the energy-efficiency message or interest in code enforcement will wane. Code officials thought this was important to motivate jurisdictions to support energy code enforcement activities and to motivate builders to comply with energy codes. They also thought this message was important to motivate home buyers to demand efficient homes and accept the higher costs associated with efficiency measures. Our informal discussions with builders during site visits reinforced this last point. Although utilities would seem to be a "natural" for "selling" efficiency, all parties were confused about the role of utilities in the WSECP.

\subsection{RECOMMENDATIONS}

We have grouped our recommendations by topic, listed in order of importance, based on the findings of this evaluation. 


\subsubsection{Continue Support of the WSEC to Maintain High Levels of Compliance}

The WSEC is a success. The role of the WSECP in that success is unclear because the training and support provided by the program are readily available without participation in the WSECP. The focus of this evaluation was on the role of the WSECP in achieving code compliance as indicated by compliance among jurisdictions participating in the WSECP. The principal difference between the participants in the WSECP and non-participants was in support provided directly to code enforcement offices. Although little is known about compliance in non-participant jurisdictions based on this evaluation, evidence from the field data indicates that even jurisdictions with little previous code experience achieved high levels of code compliance. This evidence can be used to infer that compliance among non-participants in the WSECP is comparable to that among participating jurisdictions. Accordingly, Bonneville may be able to reduce its level of support for the WSECP based on this evaluation. However, PNL recommends some minimum level of ongoing support to code officials and jurisdictions to maintain the current high levels of code compliance, especially in the face of code official concerns that compliance problems continue. Specific actions suggested by this evaluation are described below.

Increase builder and sub-contractor participation in training. Builders and sub-contractors have not been active participants in the WSECP training. Given the high levels of code compliance, they may feel that further training is unnecessary. However, code officials voiced frustration with having to provide such training on-site during inspections. As a result, it appears additional training of builders and sub-contractors is necessary. Subcontractors present a particularly weak link in this process because they typically compete on the basis of price and availability. The time and costs of attending training add directly to prices they must charge, making those who attend training potentially more expensive. One way to provide a benefit to builders and sub-contractors for attending training is to "certify" attendees and distribute lists of certified builders to code offices. If "certified" builders have fewer compliance problems, this could translate into real benefits to builders and sub-contractors in improved relations with inspectors and more rapid design approvals and inspections. 
Continue code training programs, with revisions. Interview subjects noted a variety of concerns about the training sessions, including being too elementary, too difficult, and too difficult to get to. This suggests that training programs should be more tailored to the audience. There are cost implications associated with tailoring training classes and increasing access by conducting more $\mathrm{classes}$ closer to jurisdiction offices. One alternative would be to reduce the frequency of classes, say to twice a year, tailor classes to specific audience, but hold classes in fewer locations and pay for the travel costs of students. Another alternative may be to contract for classes to be conducted by community colleges or other organizations located closer to rural communities.

Maintain and improve the technical assistance hot lines. The hot 1 ines are a popular resource for code officials and builders. They provide an efficient way of communicating up-to-date information in a timely and consistent manner. Advances in computer and FAX technologies could be used to make the hot lines a "center" for code implementation support. The needs of builders and code officials should be reviewed in light of these technical advances to improve the variety and timeliness of hot line information.

Reduce or eliminate builder incentives. Code officials felt that incentives to builders were not warranted in light of their low participation in training, high training demands during on-site inspections, and legal requirements to comply with the energy code. Given the high level of compliance observed in this evaluation, incentives do not seem to be justified.

Continue monitoring of code compliance and the WSECP. Although high levels of code compliance were observed in this evaluation there is no assurance these will continue. Code compliance should be monitored on an ongoing basis, perhaps based on the methods developed for this evaluation. This evaluation was unable to identify direct links between the WSECP and code compliance. Should Bonneville continue the WSECP, the effectiveness of the program should also continue to be evaluated.

Investigate and resolve code official concerns identified in this evaluation. Code officials cited continuing problems with compliance and concerns about lack of preparedness to enforce the code. Follow-on actions should be taken 
to see that these issues are addressed. One action would be to distribute this evaluation and note to code officials the high level of compliance. These may ease their concerns about the significance of continuing compliance problems. At the same time, actions need to be taken to address significant and systematic compliance problems through improved training and other appropriate support.

\subsubsection{Review the WSEC for Revisions to Address Problems Noted}

This evaluation received a variety of comments regarding problems with the application of the WSEC. Most of these were suggestions for ways to improve code compliance and increase the efficiency of its application. Specific suggestions include the following.

Simplify the code to recognize the two most popular compliance paths. Code officials commented that code implementation was complicated due to the multiple compliance paths. They felt that code administration could be improved by recognizing that the majority of construction follows one of two paths (thermal performance and prescriptive path) and efforts could be taken to streamline compliance under these two paths. Informal comments from builders reinforced this perspective.

Review code requirements in light of available materials. Some jurisdictions reported shortages of code-approved materials, causing compliance problems and construction delays. This suggests that improvements should be implemented to acknowledge spot shortages and offer appropriate alternatives as short-term solutions. The technical assistance hot line could be one vehicle for providing these alternatives.

Revise code to reflect realities of remodeling. This evaluation did not address the application of the WSEC to remodeling. Nevertheless, our interviews and site visits identified compliance with the WSEC for remodels as an issue. We have the impression that room additions that do not have four walls run afoul of the WSEC's provisions on window-to-floor area and other code elements. Given that room additions and French doors (another item not covered) are popular remodeling projects, the WSEC may need to be reviewed to reflect the characteristics unique to remodeling. 


\subsubsection{Develop a Position On, or Strategy For, Energy Codes and Standards as Resource Acquisition Mechanisms}

Bonneville and the NWPPC both view energy efficiency improvements as energy resources. Energy savings from efficiency codes have been a key element of Bonneville's resource acquisition strategy. However, the approach taken by Bonneville toward code adoption and support has not reflected an obvious strategy or clear role for codes and standards as resource acquisition mechanisms to the jurisdictions and code officials who must implement them and the builders who must comply with them. The results of this evaluation can provide useful direction to Bonneville if it intends to use building codes as a key element in its resource acquisition strategies. The comments received in this evaluation suggest the following.

Clarify intentions regarding the potential for future code revisions and upgrades. Building codes are revised on a routine cycle, typically three years. If revisions, including upgrades in efficiency standards, in the WSEC are envisioned by Bonneville or others, code officials and builders recommend that these revisions be synchronized with the revision cycle for other building codes. This makes it easier to anticipate and plan for all code changes at one time. Mixed signals were received regarding how extensive periodic code changes should be. Some subjects recommended a continuous process of incremental changes, which suggests minor revisions and upgrades each code revision cycle. Other subjects suggested leaving the code unchanged so that it could be fully understood. Given the high level of code compliance, this latter comment may be sound general guidance, but less relevant to the WSEC.

Clarify future role and extent of Bonneville support of code training. The level of compliance with the WSEC owes a great deal to the training on energyefficient construction techniques and codes provided by Bonneville in Washington State prior to the WSECP. This is a key lesson from this evaluation. If Bonneville intends to pursue code-based energy resource acquisition, it needs to articulate a policy toward code enforcement support and builder training.

Clarify Bonneville's position on the respective roles of codes and "market based" standards programs like Super Good Cents. The WSEC was adopted in an 
environment where two other building standards programs were operating concurrently by Bonneville: the NWECP and Super Good Cents. The energy resource objectives of these programs are similar although their implementation mechanisms are different. The NWEC is a traditional energy code whereas Super Good Cents is a utility-operated, market-based building standards program. This led to confusion among all parties about the role of Bonneville and local utilities in the WSECP and with the WSEC. Bonneville could reduce this confusion by clarifying the objectives of each program and each approach. For example, traditional code-based mechanisms could be used to establish minimum energy-efficiency levels and market-based programs could be used to improve on these levels by using "market pull" to create a demand for even higher energy codes. Under this scenario Super Good Cents could be used to "pilot" test potential code revisions with the expectation that after these had been "market proven" they would be added to the mandatory building code.

Synchronize potential code revisions to the revision cycle for other major building codes.

\subsubsection{Develop a "Marketing" Strategy and Appropriate Materials to Reinforce the Value of Energy Code Compliance}

Code compliance costs money. Jurisdictions, code officials, builders, and home buyers want to be assured the costs associated with code compliance are justified. Bonneville, the NWPPC, and the region's utilities all benefit from energy savings from codes. Bonneville or the NWPPC should take the lead in articulating a strategy to reinforce the benefits of code compliance. This strategy should include materials that explain code requirements and the benefits of code compliance. Specific actions suggested include the following:

- Articulate the resource value of energy savings associated with energy code compliance.

- Provide materials that explain the code and its requirements to jurisdictions, code officials, builders, and trade allies.

- Provide materials that describe the benefits of the code to jurisdictions, officials, builders, home buyers, lenders, and Realtors. 


\subsubsection{Enhance Participation in Code Implementation and Enforcement "Networks"}

Codes are centrally designed but locally implemented. Interview subjects indicated the presence of formal and informal networks of code officials was crucial to the smooth implementation of the code, clear identification of compliance questions, and prompt resolution of implementation problems. This is another key finding from this evaluation. It led us to recommend official support of code official "networks" to ensure consistency and support of code compliance by key implementors. Specific actions suggested include the following.

Promote the formation and operation of formal and informal networks and meetings of code officials. The networks that seemed to function the best were those that had a local focus. For example there is a group of officials from the Tri-city area in eastern Washington that created an effective network. The kind of support that may be required to stimulate the formation and maintenance of these networks will vary. It could include things like travel approval using "official" funds, assuming there are funds set aside to support code implementation.

Provide special assistance and training through these networks. Small jurisdictions are likely to have problems with work load and staffing even in the face of specific support efforts, due to the lack of staff. Established code official networks could be used to deliver supplementary or specialized training to overburdened jurisdictions and speakers for utility and builders groups. These activities also could be supported using "official" funds.

Encourage additional utility and builder involvement in code formulation and implementation. The high level of code compliance by builders seems at odds with the resistance the code faced in the state legislature. This suggests that local builders may be less afraid of energy codes than their lobbyists. It also suggests that local builders should be encouraged to participate more in the code formulation and implementation. Similarly, utilities serve the customers that live in new homes and should be expected to have interests in the codes used to build them. This recommendation seems sound for the WSEC, 
now that it has been adopted. It is not clear if it is feasible to implement this recommendation prior to code adoption or for states with less prior energy standard experience. 


\subsection{REFERENCES}

McCourt, M. 1992. Results of Sustainability Survey. Association of Washington Cities, Olympia, Washington.

Patton, M. Q. 1987. How to Use Qualitative Methods in Evaluation. Sage Publications, Newbury Park, California.

U.S. Department of Commerce, 1992. Housing Units Authorized by Building Permits: July 1992, Current Construction Reports C40/92-7, Economics and Statistics Administration, Bureau of the Census, Washington, D.C.

Washington State Building Code Council (WSBCC). 1991. Washington State Energy Code, WSBCC, Olympia, Washington.

Washington State Energy Office (WSE0). 1990. Washington State Energy Code Program Implementation Plan. Olympia, Washington. 


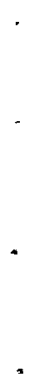




\section{APPENDIX A}

WSEO MONITORING PLAN 


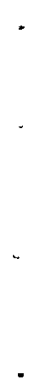

- 


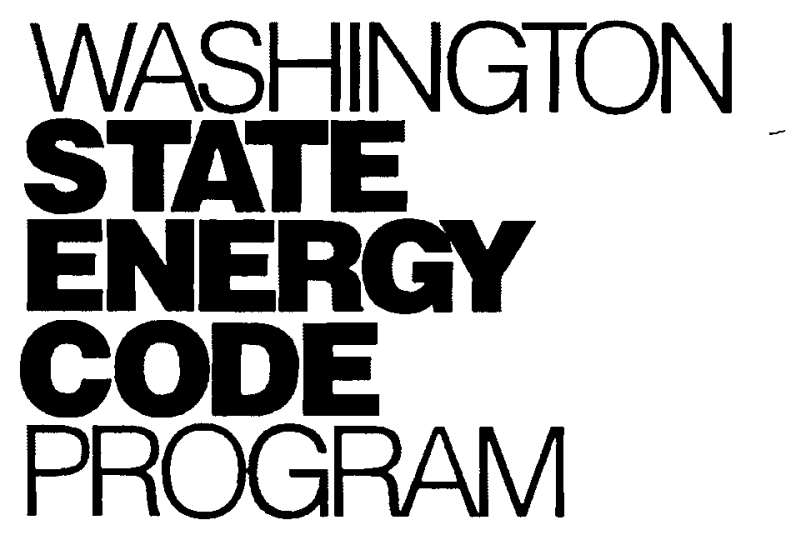

Monitoring Plan

March 1992

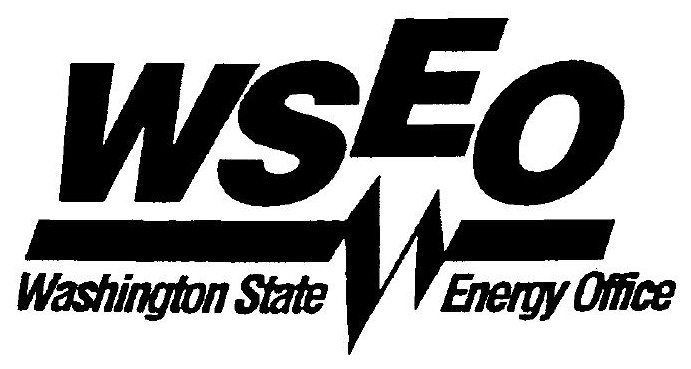




\title{
WASHINGTON STATE ENERGY CODE MONITORING PLAN
}

\author{
Approved by the Quality Assurance Committee
}

March 11, 1992

\section{BACKGROUND}

With the passage of the 1991 Washington State Energy Code (WSEC) and the Ventilation and Indoor Air Quality Code (VIAQC) the Bonneville Power Administration (BPA) agreed to support the state of Washington's efforts in enforcing the new codes. To this end BPA signed an agreement with the Washington State Energy Office (WSEO) to fund the WSEC program. Washington State electric utilities also contributed funding support to the program. The WSEC program is designed to assist building code officials and staff in enforcing the WSEC as well as the VIAQC. The October 1990 WSEC Implementation Plan embodies the WSEC program's goals and approach. These are further defined in the March 1991 WSEC Quality Assurance (QA) Plan aimed at "developing a favorable environment that assures sound energy efficient construction practices which meet the WSEC." The QA plan was developed by the QA committee which consisted of code officials, utilities and shelter industry representatives, as well as BPA, Association of Washington Cities (AWC), Washington State Association of Counties (WSAC) and WSEO staff. The QA plan requires WSEO to "develop a plan for systematic oversight and monitoring and measurement of levels of code acceptance during the remaining years of the program." WSEO will implement this plan, as outlined below, beginning in year two of the WSEC program, from July 1992 to June 1995.

\section{GUIDING PRINCIPLES AND CONSIDERATIONS}

The monitoring program has three primary goals: 1) To provide an opportunity for on site technical assistance to code officials on WSEC features; 2 ) to identify additional education and training needs; and 3) to serve as a feedback mechanism to BPA and other interested parties on code acceptance in Washington.

Several important additional considerations govern this plan. A paramount concern is weighing the need for meaningful data and the degree that monitoring staff will impact the normal professional duties of the building inspectors. To help ensure full cooperation from building code officials the QA plan provides that the collection of information will be done in a confidential manner. The format of annual monitoring report will aggregate findings in a statewide fashion. The identity of specific jurisdictions will be protected.

A critical first step is clarifying what the QA Plan is monitoring. This is described in the plan as, "level of code acceptance". In the QA plan the QA committee defined "level of code acceptance" in terms of identifying key code measures and inspection practices associated with code conformity. A preliminary list of key components follows. They were selected on the basis of their importance in terms of energy savings and as indicators of code official knowledge.

The scope of work is limited by available funding. Therefore, monitoring will be of a straight forward checklist type relying on visible inspection of electrically heated homes only. The key measures selected for monitoring will remain consistent through the monitoring program. The monitoring system will be easy to understand and use. The measurement system will be easily repeatable to allow longitudinal measurement of progress. The first year of data collection will serve as the baseline for determining code acceptance over the life of the WSEC program. 
The QA committee will review the WSEC Monitoring Plan on an annual basis to make possible revisions, modifications, and/or changes.

\section{MONITORING PLAN COMPONENTS}

Final selection of sites will be done in accordance with the sampling plan (see Attachment C).

Collaborative Problem Solving: The on-site monitoring/technical assistance visits are an opportunity for code officials and WSEO TA staff to identify energy code conformity issues, particularly inspection techniques.

\section{A. Key activities}

\section{Scheduling}

WSEO will schedule all site visits through the building code official. Site visits will be arranged at the convenience of the code official. The code official must approve all visits.

\section{Initial Interview}

Monitoring staff will review the purpose of the visit and remind officials that any information gained during the site visit will remain confidential. The interview will also be an opportunity to discuss other issues of interest: technical assistance and training needs, general problem areas, lists of products and of product availability, compliance difficulties, builders' cooperation and interest, utility support etc. This will be an opportunity to go over what the monitoring staff will do on-site.

\section{Review Files}

The monitoring staff will randomly select building department files to review the completeness of documentation. The monitoring staff will look for building permits and applications, WATTSUN print outs if necessary, checklists, heat loss calculations, and any other pertinent information related to energy code compliance.

\section{Plan Review and Site Verification}

Monitoring staff and code officials will select several projects in different phases of construction, review building plans, checklists and previous inspection reports. The number of units selected in individual jurisdictions will be specified in the sampling plan. The monitoring checklist will include some items related to the plan review process (see below).

\section{B. Data Collection and On-site Visit Protocol}

WSEO will develop a monitoring checklist (Attachment B) which will include key measures for review (see Attachment A for definitions).

- Plan exam

- Ventilation system

- Ceiling Insulation

- Wall insulation

- Floor insulation

- Duct insulation

- Slab insulation

- Window/doors plan

- Air leakage control

- Radon monitor 
During the on-site visit WSEO staff will focus on items on the check list and those measures appropriate to stage of construction. This activity will be conducted in a user friendly fashion and the monitoring staff will encourage the code officials to bring out questions and concerns about the energy code, compliance requirements, inspection techniques, etc.

Following the site visit the monitoring staff on the request of the building official and/or staff may conduct an exit interview to summarize the results of the visit, answer any additional questions, provide anecdotal results, determine what kind of follow-up may be needed (training, TA, written materials, etc.).

WSEO will provide a written draft report to the building official summarizing results of the monitoring visits and chief findings within thirty days after the visit. This report will review areas that were discussed during the visit. Unless requested by the jurisdiction, the report will not contain statistical information from the checklist. The report will contain recommendations designed to help improve the code officials efforts in dealing with nonconformance issues.

WSEO will provide regular feedback to EES trainers, AWC energy project staff, the BPA program technical representative, the Washington Association of Building Officials (WABO) and the QA committee on general findings and concerns to assist in targeting WSEC training and code implementation efforts.

\section{ANNUAL REPORT}

WSEO will develop a database for monitoring information by home and multifamily building.

WSEO will provide to BPA, WABO, trainers, and the Quality Assurance Committee an annual report which will include:

- Report by key measure aggregated for the state by year

- Summary of chief findings

- Relevant anecdotal information which identifies major trends 


\section{Washington State Energy Code Program \\ Technical Assistance \\ Monitoring Checklist Definitions}

\section{Ratings}

Rating system has four levels:

A rating of " 1 " means there are no variances with energy code/ventilation code requirements.

A rating of "2" means there are three or less minor variances with energy code/ventilation code requirements. All variances are minor and will not have a significant impact on energy conservation or system performance. Recommendations are provided to the building department.

A rating of " 3 " means there is one serious variance, or four or more minor variances with energy code/ventilation code requirements. The variances may have an impact on energy conservation or system performance. Recommendations are provided to the building department.

A rating of "4" means there is at least two serious variances with energy code/ventilation code requirements. A serious compromise of energy efficiency or system performance may result. Recommendations are provided to the building department.

\section{Definitions}

\section{Plans Exam}

a) Checklist is consistent with plans/change orders, including:

- Glazing area

- Insulation levels

- Floor area

- Window/door U-values

b) Calculations are accurate, including:

- Chapter 5 component performance calculations

- Heating system sizing calculations

- Window percentage calculations

- WATTSUN printout

The serious variances in this category would be missing, seriously incomplete or inaccurate plans, Chapter 5 calculation forms, window to floor area calculations, WATTSUN printouts, or a checklist. The compliance path chosen and the timing of the monitoring visit will affect the applicability and completeness of the documentation and will be considered. Seriously incomplete is less than $80 \%$ complete. Seriously inaccurate calculations are defined as a $20 \%$ deviation from the correct value. Alternative methods and substitute energy code documentation can be accepted at WSEO's discretion.

Minor variances in this category include minor calculation errors or omissions, inappropriate WATTSUN input, missing checklist information, compliance path not indicated, and missing or inaccurate heating system sizing calculations. 


\section{Ventilation}

Fans are in all correct locations

Fans are correctly sized

Whole house exhaust fan meets sone requirements

Engineered systems are capable of .35 to $.5 \mathrm{ACH}$

Systems operate properly

Fresh air is properly distributed

The serious variances in this category are: no whole house mechanical ventilation system; or no source of fresh air; missing all spot ventilation fans.

Minor variances in this category include: some missing spot ventilation; inappropriate fan sizes or sone ratings; incomplete fresh air distribution; incorrectly sized ducts; missing, nonfunctional, or inappropriate controls; missing calculations for engineered systems.

\section{Ceiling Insulation}

Ceiling R-value is consistent with checklist

Insulation is evenly installed

The cavity is properly ventilated

The serious variances in this category are: where $5 \%$ or more ceiling area is completely uninsulated; or where $10 \%$ or more of the ceiling area is not insulated to the minimum required $\mathrm{R}$-value.

Minor variances include: lesser degrees of missing or insufficient insulation; an incorrectly placed vapor barrier; an insufficient air cavity; missing or improperly installed baffles.

\section{Wall Insulation}

Wall R-value is consistent with checklist

Insulation is not compressed

The serious variances in this category are: where $5 \%$ or more wall area is completely uninsulated; where $10 \%$ or more of the wall area is not insulated to the minimum required R-value.

Minor variances include: lesser degrees of missing or insufficient insulation; $5 \%$ or more insulation is compressed; incorrectly located or missing vapor barriers.

\section{Floor Insulation}

Floor R-value is consistent with checklist Insulation is installed in a permanent manner Insulation is not compressed

The serious variances in this category are: where $5 \%$ or more floor area is completely uninsulated; where $10 \%$ or more of the floor area is not insulated to the minimum required R-value.

Minor variances include: lesser degrees of missing or insufficient insulation; $5 \%$ or more insulation is compressed; the vapor barrier is incorrectly located. 


\section{Duct Insulation}

Ducts are insulated to R-8 or are consistent with Systems Analysis documentation Insulation is installed in a permanent manner

Ducts in unconditioned spaces are properly sealed

The serious variances in this category would be where: $10 \%$ or more of the ducts are completely uninsulated; if $10 \%$ or more of the ducts are not insulated to the minimum required R-value.

Minor variances include: lesser degrees of missing or insufficient insulation, and improperly sealed duct joints.

\section{Slab Insulation}

Slab insulation is consistent with checklist

Insulation is appropriate for exterior below grade use

A serious variance in this category would be where: $5 \%$ or more of the slab is completely uninsulated; or, if $10 \%$ or more of the slab is not insulated to the minimum required $\mathrm{R}$-value.

Minor variances include: lesser degrees of missing or insufficient insulation; or inappropriate insulation materials.

\section{Windows/Doors}

a) Windows are consistent with checklist, including:

- Glazing area

- U-values (model/manufacturer)

b) Door U-value is consistent with checklist

Serious variances are: a $20 \%$ or greater deviation from allowed window area; a $20 \%$ or greater deviation in overall window U-value.

Minor variances include: lesser degrees of window deviations described above; insufficient door U-values.

\section{Air Leakage Control}

The following items should be sealed:

- All penetrations (plumbing, electrical, heating systems etc.)

- In heated basements: mudsill to stemwall; rim joist to mudsill and flooring

- Upper floor rim joists

- Window, skylight, and door rough openings

- Atticlcrawlspace hatch weatherstripped

- Canned lights

- Outletswitch plates

\section{Radon Monitor}

Radon monitor and information sheets are on site. 


\section{Observations \& Recommendations}

The narrative explains the training/technical assistance recommended and may detail specific observations, including some that may not be included in the above checklist. Recommended technical assistance may include additional site visits and WATTSUN assistance.

FOR THE WASHINGTON STATE ENERGY OFFICE USE ONLY 


\section{Construction Site Checklist}

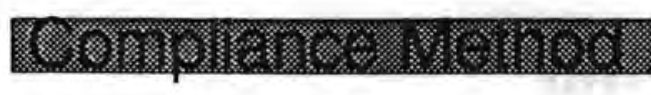

$\square$

Prescriptive Thermal Performance

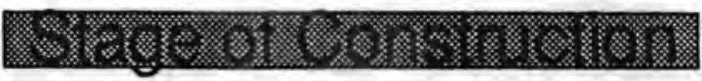

$\square$

Plan Check Foundation Framing Insulation Final

\section{S10 10}

House Size:

Heating System:

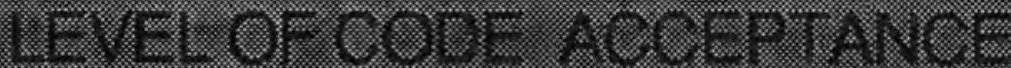

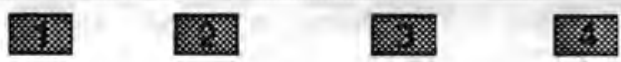

Plan Review

Slab Insulation

Wall Insulation

Windows \& Doors

Ventilation

Ceiling Insulation

Floor

Duct

Air Leakage Control

Radon Detector

\section{COMMENT}


Attachment $\mathbf{C}$

Page 1 of 4

\author{
Washington State Energy Code Program \\ Quality Assurance Plan \\ Sampling Guidelines
}

\title{
Background
}

Starting July, 1992 the Washington State Energy Office will conduct site visits to sample newly constructed homes in WSEC program jurisdictions. These sampling guidelines set targets for how many and which types of building sites will be selected for site visits.

The site visits have two purposes. The primary purpose of the site visits is to provide technical assistance to individual jurisdictions to strengthen code enforcement practices. Therefore, WSEO is focusing its efforts on providing on-site consultation during visits and individual follow-up after each visit. A secondary purpose is to provide aggregate information to assess progress towards WSEC implementation. This information will be tracked over a three year period using a qualitative checklist of key measures. This is not primarily a research project. Specific jurisdictions will be targeted for site visits depending on need. For example the jurisdiction sample is stratified by electric housing start activity to ensure that all the most active local governments are visited. Within the parameters outlined below, every attempt will be made to make the sample as broadly representative as possible.

\section{Sample Design Issues}

At the November meeting, the Quality Assurance Advisory Group identified a number of key issues and objectives for the site visit to guide the sampling plan.

\section{Housing Start Activity}

Over eighty percent of new Washington housing units are built in less than 20 percent of the jurisdictions. Seventeen percent of current program participants had more than 100 housing unit starts in 1990 . These jurisdictions accounted for $89 \%$ of 1990 housing units started by all WSEC program participants. Sixty-two percent of WSEC program participants had fewer than 20 housing unit starts. These accounted for less than 2 percent of housing activity. The QA advisory group suggested that site visits focus on the most active jurisdictions to optimize the use of resources. However, a limited number of small jurisdictions with low housing start activity might be visited to improve representation and determine if there are special problems particular to smaller jurisdictions.

WSEO recommends that site selection be stratified by size with an emphasis on the most active jurisdictions. We recommend that all of the 25 most active jurisdictions (defined in terms of electric single family housing starts) be visited. Based on estimated housing start activity for 1992 this would include all jurisdictions with 50 or more electric starts. In addition, 15 moderate activity and 10 low activity jurisdictions will be visited. A low activity jurisdiction is a jurisdiction with under five electric single family starts. Moderate activity jurisdictions are those with five or more electric starts who are not in the top 25. We estimate that between 5 and 10 building sites would be available for inspection in active jurisdictions, 2 to 4 in moderate jurisdictions, and 1 in low activity jurisdictions. 
Attachment C

Page 2 of 4

\section{Multifamily Construction}

In this plan multifamily is defined as buildings with two or more units. The QA advisory group supported a strong emphasis on multifamily. Approximately 40 percent of 1990 housing unit starts by unit in WSEC program jurisdictions were multifamily. Multifamily units are an even larger proportion of electric housing starts. There is not a direct correspondence between the electric single family and the electric multifamily housing starts. Therefore the selection of jurisdictions to be visited should be handled separately for single and multifamily. As we expect a good deal of overlap, the two jurisdiction samples could be combined for scheduling site visits.

WSEO recommends that a minimum of 50 multifamily buildings be included in the sample. We would expect, based on the average number of units per building, that 300-400 units would be covered in the sample.

\section{Prior NWEC Program Participants}

As of January, 1991, the WSEC program will include jurisdictions having no experience with strong energy codes and those with prior experience in the Northwest Energy Code. Many prior NWEC participants will have had extensive training and familiarity with residential codes, and can be expected to be further along the learning curve. Since the technical assistance part of the WSEC program is targeted to jurisdictions without prior exposure to residential codes, the QA advisory group urged focusing site visit resources on jurisdictions without prior experience with the NWEC. However, excluding site visits to homes in jurisdictions with prior experience with the NWEC program would not provide an accurate picture of how the program is proceeding.

WSEO recommends that the sample not be stratified by prior NWEC program participation. However, units in NWEC and non-NWEC jurisdictions should be compared in the analysis.

\section{Jurisdictions Served by Full or Partial-Requirement Utilities}

The QA advisory group expressed concern that jurisdictions in public utility service territories tend to be smaller and have fewer technical resources. Further the utilities themselves tend to be smaller and have fewer resources to support WSEC code implementation.

Although the WSEC resource is a regional resource, we recognize that jurisdictions in smaller public utilities may get greater benefit from the site visits. As a compromise we suggest that all 25 most active jurisdictions in the program be visited regardless of utility type. However, site visits in low and moderate activity jurisdictions will target those served by public utilities.

\section{East vs West of the Cascades}

The advisory committee also indicated that utilities east of the Cascades not be excluded. Focus on the west side is unavoidable since most of the new housing activity is in the Central Puget Sound Area. WSEO suggests that representation of Eastern Washington Jurisdictions be proportional within the parameters described above.

\section{At Which Stage of Construction Will Site Visit Occur?}

WSEO has the resources to make only one visit to each construction site. There is no optimal stage for inspection. At each stage some measures are either not installed or not accessible. Because of this, our site visit protocol is organized by measure rather than by whole house. At each site, depending on the timing of the visit, we expect to be able inspect only a part of the entire checklist. To minimize inconvenience to potential occupants, we do not expect to visit homes after occupants have moved in. 


\section{Sampling Strategy}

We will select construction sites to visit in a two phase process. In the first phase jurisdictions are selected out of the current years WSEC program participants. We will use the prior years electric single and multifamily housing start data to stratify the sample in high, moderate, and low activity jurisdictions. We will visit all of the twenty-five most active jurisdictions. The jurisdictions in this sample are expected to remain unchanged during site visits in later years. Among low and moderate activity jurisdictions, we expect to sample different jurisdictions each year. The majority of the jurisdictions to visit in these categories will be selected randomly. A small number of jurisdictions may be targeted because of technical assistance needs.

In the second phase of sampling specific new housing units will be selected for site visits at each sampled jurisdiction. For each sampled jurisdiction a target number of site visits will be set based on housing start activity. If the number of available housing units is at or below the target level, all available housing units will be selected. An "available housing unit" is defined as homes between the foundation inspection phase and prior to occupancy. If the number of available homes is greater than the target number we will randomly sample the nth cases. Target levels are listed below in ().

For Single family units

- The 5 most active jurisdictions (6)

- The next 20 most active jurisdictions (3-5)

- Fifteen jurisdictions with 6 to 50 annual electric housing starts (3)

- Ten jurisdictions with 5 or fewer annual electric housing starts (1)

\section{For Multifamily units}

- More than 100 electric multi-family buildings (3)

- More than 10 electric multi-family buildings (2)

- Ten or fewer electric multi-family buildings (1)

Because of the prevalence of insulation measures on the checklist and because of limited window accessibility, homes getting insulation inspections will targeted in cases where there are more than the minimum houses. The following selection criteria will be used:

- All homes will be selected regardless of construction phase if available homes number less than target levels.

- If all more available homes than the target level, all homes in the insulation inspection stage will be selected first (up to 75 percent of jurisdiction quota).

- The remaining housing units to fill the quota will be selected randomly.

For multifamily the sampling unit is the building (detached complex). However individual units will be counted towards the goal.

At the halfway point in each year's site visit schedule we will review the sampling coverage for each component on the checklist and assess whether targeting strategies need to be revised. 
The following are proposed sample parameters.

1. A total of 150 single family units will be visited in an estimated 50 jurisdictions. Fifty multifamily buildings will be visited.

2. All of the twenty-five most active jurisdictions will be sampled. In the five most active jurisdictions, six sites will be targeted. In the next twenty, a maximum of five and minimum of three sites will be visited.

3. Ten moderate activity jurisdictions will be visited. Three sites will be visited at each.

4. Five jurisdictions with 5 or fewer annual electric housing starts will be visited. At each, one site will be visited.

5. Among low and moderate activity jurisdictions in the program at least 60 percent of jurisdictions getting site visits will be served by public utilities.

6. East versus west of the Cascades will be represented proportionately within the above sample parameters.

Single Family Sample

$\begin{array}{lccc}1990 \text { Activity } & \begin{array}{c}\text { Jurisdictions } \\ \text { Sampled }\end{array} & \begin{array}{c}\text { Building } \\ \text { Visits }\end{array} & \begin{array}{c}\text { Unit } \\ \text { Visits }\end{array} \\ \text { High } & 25 \text { (All) } & \text { NA } & 90 \\ \text { Moderate } & 15 & \text { NA } & 50 \\ \text { Low } & 10 & \text { NA } & 10\end{array}$

\section{Multifamily Sample}

$\begin{array}{lccc}100 \text { buildings more } & 4 \text { (All) } & 15 & \text { NA } \\ 10-100 & 11 & 25 & \text { NA } \\ 10 \text { or fewer } & 10 & 10 & \text { NA }\end{array}$

We expect there will be a great deal of overlap between jurisdictions in the single and multifamily samples. After accounting for this overlap, an estimated 75 WSEC program jurisdictions will be visited under the program each year.

These guidelines are designed to provide general guidelines for select Quality Assurance site visit candidates. WSEO will revisit these guidelines after the first year and revise them as necessary. 
APPENDIX B

WSEC MONITORING CHECKLIST 


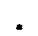

- 
APPENDIX B

\section{WSEC MONITORING CHECKLIST}

\section{Compliance Level}

$1=$ No variances.

$2=$ Less than 3 minor variances. No significant impact on performance.

$3=1$ serious variance or, 4 or more minor variance. May have an impact on energy performance.

4 = At least 2 serious variances. A serious energy performance compromise.

\section{Definitions}

CEILING INSULATION

R-value consistent with checklist.

Insulation evenly installed.

Cavity properly ventilated.

Serious Variances

-> 5\% area completely uninsulated

-> $10 \%$ area not insulated to minimum required $\mathrm{R}$-value

Minor Variances

- Lesser degrees of missing or insufficient insulation

- Incorrectly placed vapor barrier

- Insufficient air cavity

- Missing or improperly installed baffles

WALL INSULATION

R-value consistent with checklist.

Insulation not compressed.

Serious Variances

.> $5 \%$ area completely uninsulated

- $>10 \%$ area not insulated to minimum required $R$-value

Minor Variances

- Lesser degrees of missing or insufficient insulation

- $>$ $5 \%$ insulation compressed

- Incorrectly placed or missing vapor barrier 
FLOOR INSULATION

R-value consistent with checklist.

Insulation installed in a permanent manner.

Insulation not compressed.

Serious Variances

.> 5\% area completely uninsulated

-> $10 \%$ area not insulated to minimum required $R$-value

Minor Variances

- Lesser degrees of missing or insufficient insulation

.> 5\% insulation compressed

- Incorrectly placed or missing vapor barrier

DUCT INSULATION

Ducts insulated to R-8 or consistent with Systems Analysis documentation. Insulation installed in a permanent manner.

Ducts in unconditioned spaces are properly sealed.

Serious Variances

$\rightarrow 10 \%$ ducts completely uninsulated

-> $10 \%$ of ducts not insulated to minimum required $R$-value

\section{SLAB INSULATION}

Insulation is consistent with checkl ist.

Insulation appropriate for exterior below grade use.

Serious Variances

.$>5 \%$ slab completely uninsulated

.> $10 \%$ of slab is not insulated to minimum required $R$-value.

Minor Variances

- Lesser degrees of missing or insufficient insulation

- Inappropriate insulation materials

WINDOWS/DOORS

Windows consistent with the check list including glazing area, U-values (model/mfg).

Door U-value is consistent with checklist.

Serious Variances

-> 20\% greater deviation from allowed window area

-> $20 \%$ deviation in overall window U-value

Minor Variances

- Lesser degrees of window deviations

- Insufficient door U-values

Source: Washington State Energy Code Program Monitoring Plan, March 1992 


\section{APPENDIX C}

PNL RECOMMENDATIONS TO WSEO 

August 28, 1992

John Devine

Washington State Energy Office

809 Legion Way, SE

P.0. Box 43165

Olympia, WA 98504-3165

\section{COMMENTS/SUGGESTIONS FOR CONTINUED WSEO COMPLIANCE EVALUATION}

Dear Mr. Devine:

Since speaking with some of you on the phone (John and Dave), I have reviewed the compliance procedure as I have been tasked under the BPA project. I have not been able to connect with you for any of your compliance audits as yet but have put togather some comments and suggestions that might be useful. I have compiled these with Dana Durfee of the Portland office who is going to be working with the collected data.

In general, the compliance inspection procedure appears complete and reasonable for the kind of compliance review required. My understanding of actual field practice of the procedure (as detailed by WSEO compliance auditors) also appears to be appropriate for the task at hand. Site visits with WSEO auditors in the near future will provide an opportunity for first hand experience with the procedure. Until then, a few suggestions are made here that may aid in the data collection effort and effective identification of code deficiencies or areas in need of improvement.

- The site checklist does not indicate the recording of total home square footage or component square footage such as for walls, floors, ceilings, windows, and doors. These values will be needed for any compliance modelling required as a part of the BPA compliance project. An indication of conditioned vs. overall square footage would also be needed.

- The variance types and categories noted in the procedure appear very appropriate for this code compliance. In order to fully assess compliance deficiencies it seems necessary to identify these specific code discrepancies or shortcomings. The current checklist only provides spaces for checking the level of compliance as described in the 
John Devine

August 28, 1992

Page 2

procedure. It might be more instructive to be able to specifically and consistently identify the actual code variations that create the compliance level for accurate comparison from site to site.

- In order to assist code officials or builders in complete compliance, it will be useful to be able to site specific building practices that may be recurring compliance deficiencies. This requires that specific building practices or oversights that contribute to the noted variances be recorded. This information would be invaluable in any future code training.

- Since it is well known that inspection is as much an art as a science, it would seem valuable if not necessary for the WSEO auditors to occasionally compare notes concerning inspection details. This would help assure that consistent code variances are being applied to consistent code deficiencies. This could be in the form of a simple phone review of specific findings to assure that consistency is maintained and unusual occurrences are dealt with in similar manners.

The attached checklist version shows one possible format for including the kind of details suggested above. The deficiency with this version is the lack of room for notes which needs to be large to accommodate important details. This checklist version is only an example of a format for identifying specific code variances. The intent is not to advocate changes in checklists, but rather to identify better compliance support and data gathering.

If some of the details suggested here are already in practice, please ignore the comments. I look for to tagging along on inspections in the near future. Please feel free to call me at (509)375-3655 with any comments or feedback.

Sincerely,

Eric E. Richman 
CONSTRUCTION STTE CHECKLIST

ID NUMBER:

DATE:

WSEO REF:

HEATING SYSTEM TYPE: [ ] Heat Pump [ ] Central [ ] Zoned

COMPlince Path: [ ] Prescriptive [] Thermal Performance [] System Analysis

STAGE OF CONSTRUCTION: [ ] Plan Check [ ] Foundation [ ] Framing [ ] Insulation [ ] Final

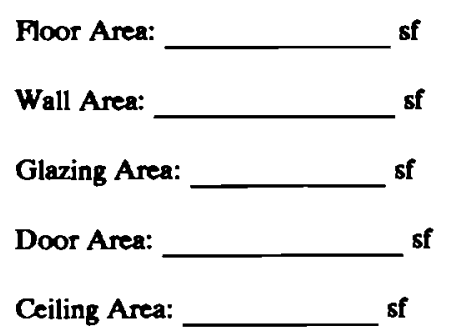

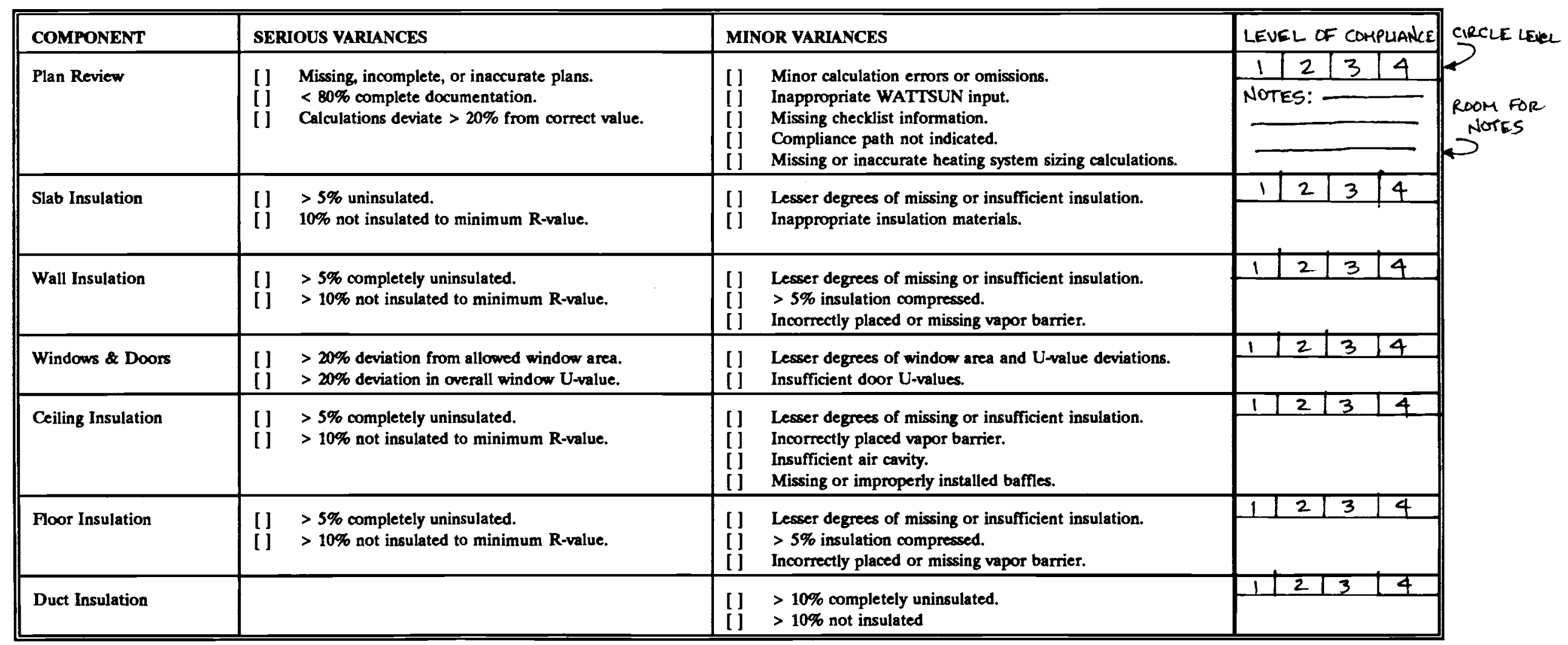

COMMENTS: 


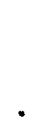

1 
APPENDIX D

RICHMAN LETTER 

Pacific Northwest Laboratories Portland Operations

September 29, 1992

John Devine

Washington State Energy Office

809 Legion Way, SE

P.0. Box 43165

01 ympia, WA 98504-3165

Dear John,

During our last phone conversation we talked about the issue of inspected items that are likely to be reworked or fixed since many of the inspections are first time for the local inspector also. As you know, in order to assess compliance levels and impacts it is very important to know actual levels of compliance as finally installed.

You mentioned that it might be possible to identify which inspections contain "fixed" items. Since this information is extremely important to the overall success of the assessment part of this study, a way needs to be found to reasonably implement some identification process. Without an indication of actual as-built code deficiencies, it will be nearly impossible to derive any reasonable assessment of actual code compliance. Some possible situations for identification come to mind as suggestions:

A) Identify inspections where all discrepancies are also noted by the local inspector and therefore likely to be fixed.

(These data points are likely not to be useable in much of the assessment since it is not known if the discrepancies remain or were fixed)

B) Identify inspections where all discrepancies are also noted by the local inspector and are sure to be fixed. This might include failed inspections or other assurance.

(This data could be used as evidence of complete compliance)

C) In the case of mixed inspections: Within each inspection identify items that are either likely or sure to be fixed.

(This data could also be used for complete and incomplete compliance in most cases) 
John Devine

September 29, 1992

Page 2

Perhaps there are other formats or methods that can be used to achieve this needed identification. Please let me know what can be done in this area and if a meeting for discussion might be useful. I am also looking forward to seeing a copy of your new inspection checklist whenever it is ready.

Thank You,

Eric E. Richman

Battelle

Box 999 K5-08

Richland, WA 99352 


\section{APPENDIX E}

\section{CONSTRUCTION SITE CHECKLIST DATA ANALYSIS BUILDING PROTOTYPES}




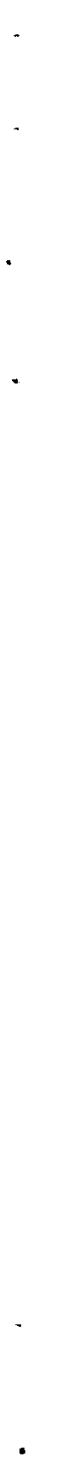




\section{APPENDIX E}

CONSTRUCTION SITE CHECKLIST DATA ANALYSIS BUILDING PROTOTYPES

\begin{tabular}{|c|c|c|}
\hline $\begin{array}{l}\text { Prototype: } \\
\text { Description: } \\
\text { \% New Housing Stock: }\end{array}$ & $\begin{array}{l}\text { Smal1 } \\
52 \%\end{array}$ & Single Story Rambler \\
\hline $\begin{array}{l}\text { Component } \\
\text { Gross Floor Area } \\
\text { Number of Stories } \\
\text { Floor Area } \\
\text { Net Wall Area } \\
\text { Ceiling / Roof Area } \\
\text { Door Area } \\
\text { Foundation Type } \\
\text { Perimeter Length } \\
\text { Glazed Area } \\
\text { Total Envelope Area }\end{array}$ & & $\begin{array}{l}\frac{\text { Area }}{1,344 \mathrm{ft}^{2}} \\
\text { One } \\
1,344 \mathrm{ft}^{2} \\
1,161 \mathrm{ft}^{2} \\
\quad 1,344 \mathrm{ft}^{2} \\
40 \mathrm{ft}^{2} \\
\text { Crawl space } \\
172 \mathrm{ft}^{2} \\
175 \mathrm{ft}^{2} \\
13 \% \text { of gross floor area } \\
4,064 \mathrm{ft}^{2}\end{array}$ \\
\hline $\begin{array}{l}\text { Prototype: } \\
\text { Description: } \\
\text { \% New Housing Stock: }\end{array}$ & $\begin{array}{l}\text { Medium } \\
14 \%\end{array}$ & Two Story \\
\hline $\begin{array}{l}\text { Component } \\
\text { Gross Floor Area } \\
\text { Number of Stories } \\
\text { Floor Area } \\
\text { Net Wall Area } \\
\text { Ceiling / Roof Area } \\
\text { Door Area } \\
\text { Foundation Type } \\
\text { Perimeter Length } \\
\text { Glazed Area } \\
\text { Total Envelope Area }\end{array}$ & & $\begin{array}{l}\frac{\text { Area }}{1,848 \mathrm{ft}^{2}} \\
\text { Two } \\
1,288 \mathrm{ft}^{2} \\
1,768 \mathrm{ft}^{2} \\
\quad 1,288 \mathrm{ft}^{2} \\
40 \mathrm{ft}^{2} \\
\text { Crawlspace / Uriheated Garage } \\
148 \mathrm{ft}^{2} \\
240 \mathrm{ft}^{2} \\
13 \% \text { of gross floor area } \\
4,624 \mathrm{ft}^{2}\end{array}$ \\
\hline
\end{tabular}


Prototype:

Description:

Large

\% New Housing Stock: $\quad 35 \%$

Split Level

Component

Gross Floor Area

Number of Stories

Floor Area

Net Wall Area

Below Grade Wall Area

Ceiling / Roof Area

Door Area

Foundation Type

Perimeter Length

Glazed Area

Total Envelope Area

Area

2,352 $\mathrm{ft}^{2}$

One Above, One $70 \%$ Below Grade

$2,352 \mathrm{ft}^{2}$

$1,278 \mathrm{ft}^{2}$ above grade

$736 \mathrm{ft}^{2}$

$60 \mathrm{ft}^{2}, 288 \mathrm{ft}^{2}$

Daylight Basement / Partial Crawlspace $160 \mathrm{ft}$

$258 \mathrm{ft}^{2}$

$11 \%$ of gross floor area

$5,244 \mathrm{ft}^{2}$

Source: Northwest Power Planning Council 


\section{APPENDIX $F$}

BUILDING COMPONENT UA CALCULATION METHOD 


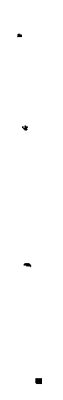




\section{APPENDIX $F$}

\section{BUILDING COMPONENT UA CALCULATION METHOD}

\section{F.1 SLAB ON-GRADE}

\section{Assumptions:}

The slab is fully insulated.

Analysis:

$$
U A_{\text {slab }}=\left[F_{\text {insul }} *(i)+F_{\text {none }}^{\prime} *(1-i)\right] * P_{\text {slab }}
$$

Where:

$$
\begin{aligned}
& F_{\text {insul }}=F-v a l u e \text { for fully insulated slab }=0.36 \mathrm{Btu} / \mathrm{F}^{*} \mathrm{hr} \mathrm{F}^{*} \mathrm{ft} \\
& F_{\text {none }}=\mathrm{F} \text {-value for uninsulated slab }=0.73 \mathrm{Btu} / \mathrm{F}^{*} \mathrm{hr} \mathrm{ft}^{\text {not }} \\
& \mathrm{P}^{\text {slab }}=\text { perimeter of slab [ft] }
\end{aligned}
$$

Table F.1.1 Protoype Slab-On-Grade i-Factors

\begin{tabular}{||l|l|}
\hline Compliance Level & Slab I-Factor \\
\hline \hline 1 & 1.00 \\
\hline 2 & 0.98 \\
\hline 3 & 0.94 \\
\hline 4 & 0.89 \\
\hline
\end{tabular}

Table F.1.2 Prototype Slab On-Grade UA Values By Compliance Level

\begin{tabular}{||l|l|l|l|l|l||}
\hline \hline Prototype & Perimeter [ft' & Level 1 UA & $\begin{array}{l}\text { Level 2 } \\
\text { UA }\end{array}$ & $\begin{array}{l}\text { Level 3 } \\
\text { UA }\end{array}$ & $\begin{array}{l}\text { Level 4 } \\
\text { UA }\end{array}$ \\
\hline \hline Smal1 & 172 & 62 & 63 & 66 & 69 \\
\hline Medium & 148 & 53 & 54 & 57 & 59 \\
\hline Large & 160 & 58 & 59 & 61 & 64 \\
\hline
\end{tabular}




\section{F.2 FLOOR}

Assumptions:

The crawlspace is vented with a 7-1/2 mph wind.

The framing members represent $15 \%$ of the floor heat loss area.

Analysis:

There are two heat flow paths through the floor; the frame and cavity.

Table F.2.1 Prototype Floor R-Values

\begin{tabular}{||l|l|l|}
\hline & Frame Path R-Value & Cavity Path R-Value \\
\hline \hline Inside air film & 0.92 & 0.92 \\
\hline Carpet \& Pad & 2.08 & 2.08 \\
\hline $1 / 2$ " plywood & 0.62 & 0.62 \\
\hline $2 \times 8$ joist & 9.40 & $\ldots-$ \\
\hline Batt insulation & ---- & $x^{(1)}$ \\
\hline Outside air film & 0.25 & 0.25 \\
\hline \hline Total R-value & 13.27 & $3.87+x^{(1)}$ \\
\hline \hline (1) Insulation R-value varies with the compliance level. \\
\hline
\end{tabular}

$U A_{\text {floor }}=\underset{A_{\text {floor }}}{\left[\left(1 / R_{\text {frame }}\right) \star f\right]} * A_{\text {floor }}+\left\{\left[\left(1 / R_{\text {cavity }}\right) \star i+\left(1 / R_{\text {none }}\right) \star(1-i)\right] \star[1-f]\right\} *$ where: $R_{\text {frame }}=$ frame heat loss path total $R-v a l u e=13.27 \mathrm{hr} * \mathrm{~F} * \mathrm{ft}^{2} / \mathrm{Btu}$ $R_{\text {cayaty }}=$ total $R$-value through insulated cavity $=(3.87+x)$ $\mathrm{hr}^{\text {cavity }} \mathrm{ft}^{2}$ /Btu

$R_{\text {none }}=$ total $R$-value through uninsulated cavity $=3.87 \mathrm{hr}^{*} \mathrm{~F} * \mathrm{ft}^{2} / \mathrm{Btu}$

$A_{\text {floor }}^{\text {none }}=$ total floor area $\left[\mathrm{ft}^{2}\right]$

$f=$ framing factor

$\mathbf{i}=$ fraction of cavity insulated 
Table F.2.2 Prototype Floor i-Factors

\begin{tabular}{|l|l|}
\hline Compl iance Level & Floor I-Factor \\
\hline \hline 1 & 1.00 \\
\hline 2 & 0.97 \\
\hline 3 & 0.94 \\
\hline 4 & 0.88 \\
\hline
\end{tabular}

Table F.2.3 Prototype Floor UA Values By Compliance Level

\begin{tabular}{||l|l|l|l|l|l||}
\hline \hline Prototype & $\begin{array}{l}\text { Area } \\
{\left[\mathrm{ft}^{2}\right]}\end{array}$ & $\begin{array}{l}\text { Leve1 1 } \\
\text { UA }\end{array}$ & $\begin{array}{l}\text { Leve1 2 } \\
\text { UA }\end{array}$ & $\begin{array}{l}\text { Leve1 3 } \\
\text { UA }\end{array}$ & $\begin{array}{l}\text { Leve1 4 } \\
\text { UA }\end{array}$ \\
\hline \hline Smal1 & 1344 & 48 & 56 & 58 & 67 \\
\hline Medium & 1288 & 46 & 54 & 55 & 64 \\
\hline Large & 2352 & 85 & 99 & 101 & 118 \\
\hline
\end{tabular}

\section{F.3 HALL}

Assumptions:

The framing members represent $15 \%$ of the wall heat loss area.

Analysis:

There are two heat flow paths through the wall; the frame and cavity. 
Table F.3.1 Prototype Nall R-Values

\begin{tabular}{||l|l|l||}
\hline & Frame Path R-Value & Cavity Path R-Value \\
\hline \hline Inside air film & 0.68 & 0.68 \\
\hline $1 / 2$ " gypsum & 0.45 & 0.45 \\
\hline $2 \times 6$ frame & 6.88 & $\ldots$ \\
\hline Batt insulation & $-\ldots$ & $x^{(1)}$ \\
\hline $1 / 2$ " plywood & 0.62 & 0.62 \\
\hline $\begin{array}{l}\text { Wood lapped } \\
\text { siding }\end{array}$ & 0.81 & 0.81 \\
\hline $\begin{array}{l}\text { Outside air } \\
\text { film }\end{array}$ & 0.17 & 0.17 \\
\hline \hline \begin{tabular}{l} 
Total R-value \\
\hline \hline (1) Insulation R-value varies with the compliance level.
\end{tabular} \\
\hline
\end{tabular}

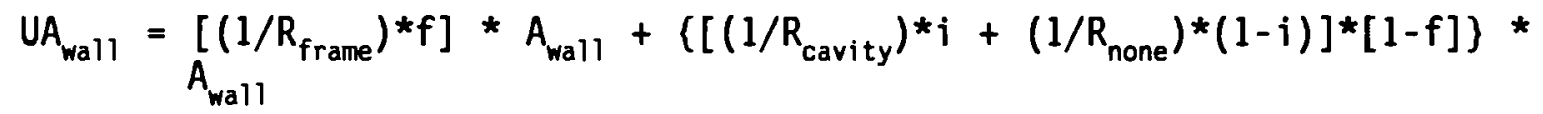
Where: $R_{\text {frame }}=$ frame heat loss path total $R$-value $=9.61 \mathrm{hr} * \mathrm{~F}^{*} \mathrm{ft}^{2} / \mathrm{Btu}$ $R_{\text {caajety }}=$ total $R$-value through insulated cavity $=(2.73+x)$

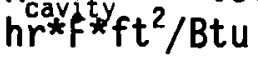

$R_{\text {none }}=$ total $\mathrm{R}$-value through uninsulated cavity $=2.73 \mathrm{hr}^{\star} \mathrm{f} * \mathrm{ft}^{2} / \mathrm{Btu}$

$A_{\text {wa } 11}^{\text {none }}=$ total wall area $\left[\mathrm{ft}^{2}\right]$

$f^{\text {wal }}=$ framing factor

$i=$ fraction of cavity insulated

Table F.3.2 Prototype Wall i-Factors

\begin{tabular}{||l|l|}
\hline Compl iance Level & Wall I-Factor \\
\hline \hline 1 & 1.00 \\
\hline 2 & 0.97 \\
\hline 3 & 0.94 \\
\hline 4 & 0.88 \\
\hline
\end{tabular}


Table F.3.3 Prototype Wall UA Values By Compliance Level

\begin{tabular}{||l|l|l|l|l|l||}
\hline Prototype & $\begin{array}{l}\text { Area } \\
{\left[\mathrm{ft}^{2}\right]}\end{array}$ & $\begin{array}{l}\text { Leve1 } \\
\text { 1 UA }\end{array}$ & $\begin{array}{l}\text { Leve1 } \\
\text { 2 UA }\end{array}$ & $\begin{array}{l}\text { Leve1 } \\
\text { 3 UA }\end{array}$ & $\begin{array}{l}\text { Leve1 } \\
\text { 4 UA }\end{array}$ \\
\hline \hline Sma11 - Zone I & 1161 & 64 & 73 & 82 & 87 \\
\hline Sma11 - Zone II & 1161 & 55 & 65 & 74 & 78 \\
\hline Medium - Zone I & 1768 & 97 & 111 & 126 & 133 \\
\hline Medium - Zone II & 1768 & 83 & 99 & 113 & 119 \\
\hline Large - Zone I & 1278 & 70 & 80 & 91 & 96 \\
\hline Large - Zone II & 1278 & 60 & 72 & 82 & 86 \\
\hline
\end{tabular}

\section{F.4 CEILING}

Assumptions:

The attic is vented with a $7-1 / 2 \mathrm{mph}$ wind.

The framing members represent $15 \%$ of the ceiling heat loss area.

Analysis:

There are two heat flow paths through the floor; the frame and cavity.

Table F.4.1 Prototype Ceiling R-Values

\begin{tabular}{||l|l|l||}
\hline & Frame Path R-Value & Cavity Path R-Value \\
\hline \hline Inside air film & 0.61 & 0.61 \\
\hline 1/2" gypsum & 0.45 & 0.45 \\
\hline 2x6 frame & 6.88 & $\ldots .-$ \\
\hline Batt insulation & $\ldots \ldots$ & $x^{(1)}$ \\
\hline Outside air film & 0.25 & 0.25 \\
\hline \hline Total & 8.19 & $1.31+x^{(1)}$ \\
\hline \hline (1) Insulation R-value varies with the compliance level. \\
\hline
\end{tabular}




$$
\begin{aligned}
& U A_{\text {ceiling }}=\left[\underset{* A_{\text {ceiling }}}{\left[\left(1 / R_{\text {frame }}\right) * f\right] * A_{\text {ceiling }}}+\left\{\left[\left(1 / R_{\text {cavity }}\right) * i+\left(1 / R_{\text {none }}\right) *(1-i)\right] *[1-f]\right)\right. \\
& \text { Where: } R_{\text {frame }}=\text { frame heat loss path total } R \text {-value }=8.19 \mathrm{hr} * \mathrm{f} * \mathrm{ft}^{2} / \mathrm{Btu} \\
& R_{\text {cavity }}=\text { total } R \text {-value through insulated cavity }=(1.31+x) \\
& \text { hr*f: } \left.\mathrm{ft}^{2} / \mathrm{Btu}\right] \\
& R_{\text {none }}=\text { total } R-v a l u e \text { through uninsulated cavity }=1.31 \mathrm{hr} * \mathrm{f} * \mathrm{ft}^{2} / \mathrm{Btu} \\
& A_{\text {ceiling }}^{\text {none }}=\text { total ceiling area }\left[\mathrm{ft}^{2}\right] \\
& f \stackrel{\text { framing factor }}{ } \\
& i \text { = fraction of cavity insulated }
\end{aligned}
$$

Table F.4.2 Prototype Ceiling i-Factors

\begin{tabular}{|l|l|}
\hline Compliance Level & Ceiling I-Factor \\
\hline \hline 1 & 1.00 \\
\hline 2 & 0.97 \\
\hline 3 & 0.94 \\
\hline 4 & 0.88 \\
\hline
\end{tabular}

Table F.4.3 Prototype Ceiling UA Values By Compliance Level

\begin{tabular}{||l|l|l|l|l|l||}
\hline Prototype & $\begin{array}{l}\text { Area } \\
{\left[\mathrm{ft}^{2}\right]}\end{array}$ & $\begin{array}{l}\text { Level } \\
1 \text { UA }\end{array}$ & $\begin{array}{l}\text { Level } \\
\text { 2 UA }\end{array}$ & $\begin{array}{l}\text { Level } \\
3 \text { UA }\end{array}$ & $\begin{array}{l}\text { Leve1 } \\
4 \text { UA }\end{array}$ \\
\hline \hline Sma11 & 1344 & 54 & 79 & 105 & 108 \\
\hline Medium & 1288 & 52 & 76 & 101 & 103 \\
\hline Large & 2352 & 94 & 139 & 184 & 188 \\
\hline
\end{tabular}

\section{F.5 WINDOWS}

Analysis:

$$
U A_{\text {window }}=\left(U_{\text {total }} * i\right) * A_{\text {window }}
$$

Where: $U_{\text {total }}=$ window $U$-value $=0.40 \mathrm{Btu} / \mathrm{hr} * \mathrm{f} * \mathrm{ft}^{2}$

$A_{\text {window }}^{\text {total }}=$ total window area $\left[\mathrm{ft}^{2}\right]$

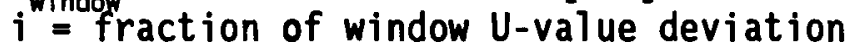


Table F.5.1 Prototype Nindow $\mathfrak{i}$-Factors

\begin{tabular}{||l|l|}
\hline Compliance Level & Window I-Factor \\
\hline \hline 1 & 1.00 \\
\hline 2 & 1.11 \\
\hline 3 & 1.21 \\
\hline 4 & 1.30 \\
\hline
\end{tabular}

Table F.5.2 Prototype Nindow UA Value By Compliance Level

\begin{tabular}{||l|l|l|l|l|l|}
\hline \hline Prototype & Area $\left[\mathrm{ft}^{2}\right]$ & Level 1 UA & Level 2 UA & Level 3 UA & Leve1 4 UA \\
\hline \hline Sma11 & 175 & 70 & 77 & 84 & 91 \\
\hline Medium & 240 & 96 & 106 & 115 & 125 \\
\hline Large & 258 & 103 & 113 & 124 & 134 \\
\hline
\end{tabular}

\section{F.6 DOORS}

Analysis:

$$
\begin{aligned}
& U A_{\text {door }}=\left(U_{\text {total }}{ }^{*} i\right) * A_{\text {door }} \\
& \text { Where: } U_{\text {total }}=\text { door } U \text {-value }=0.20 \mathrm{Btu} / \mathrm{hr}^{*} \mathrm{~F} * \mathrm{ft}^{2} \\
& A_{\text {door }}^{\text {total }}=\text { total door area }\left[\mathrm{ft}^{2}\right]
\end{aligned}
$$

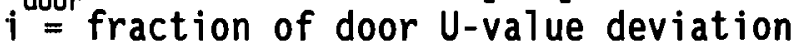

\begin{tabular}{||l|l|}
\hline Compliance Level & Door I-Factor \\
\hline \hline 1 & 1.00 \\
\hline 2 & 1.11 \\
\hline 3 & 1.21 \\
\hline 4 & 1.30 \\
\hline
\end{tabular}


Table F.6.2 Prototype Door UA Value By Compliance Level

\begin{tabular}{||l|l|l|l|l|l||}
\hline \hline Prototype & $\begin{array}{l}\text { Area } \\
{\left[\mathrm{ft}^{2}\right]}\end{array}$ & $\begin{array}{l}\text { Leve1 } \\
\text { 1 UA }\end{array}$ & $\begin{array}{l}\text { Leve1 } \\
\text { 2 UA }\end{array}$ & $\begin{array}{l}\text { Leve1 } \\
\text { 3 UA }\end{array}$ & $\begin{array}{l}\text { Leve1 } \\
\text { 4 UA }\end{array}$ \\
\hline \hline Smal1 & 40 & 8 & 9 & 10 & 10 \\
\hline Medium & 40 & 8 & 9 & 10 & 10 \\
\hline Large & 60 & 12 & 13 & 14 & 16 \\
\hline
\end{tabular}

\section{F.7 INFILTRATION}

\section{Assumptions:}

The ventilation and air leakage control was not included in the component analysis. The natural infiltration rate is assumed to be constant at 0.35 $\mathrm{ACH}$ for each prototype.

\section{Analysis:}

$$
\mathrm{UA}_{\text {infiltration }}=0.018 * \text { Volume * } \mathrm{ACH}
$$

Where: Volume $=$ total house volume $\left[\mathrm{ft}^{3}\right]$

$\mathrm{ACH}=$ air changes per hour $=0.35 \mathrm{ACH}$

Table F.7.1 Prototype Infiltration UA Values

\begin{tabular}{||l|l|l|}
\hline \hline Prototype & Volume $\left[\mathrm{ft}^{3}\right]$ & Level 1-4 UA \\
\hline \hline Smal1 & 10,752 & 68 \\
\hline Medium & 14,784 & 93 \\
\hline Large & 18,816 & 119 \\
\hline
\end{tabular}




\section{F.8 OVERALL}

Slab-On-Grade Foundation, Zone I

$\begin{aligned} U A_{\text {total }}=U A_{\text {slab }} & +U A_{\text {wall-zone I }}+U A_{\text {ceiling }}+U A_{\text {window }}+U A_{\text {door }} \\ & +U A_{\text {infiltration }}\end{aligned}$

Slab-On-Grade Foundation, Zone II

$\begin{aligned} U A_{\text {total }}=U A_{\text {slab }} & +U A_{\text {wall-zone II }}+U A_{\text {ceiling }}+U A_{\text {window }}+U A_{\text {door }} \\ & +U A_{\text {infiltration }}\end{aligned}$

Crawlspace Foundation, Zone I

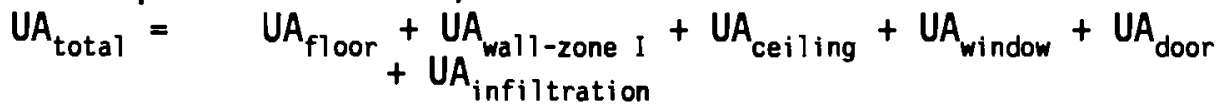

Crawlspace Foundation, Zone II

$U A_{\text {total }}=\quad U A_{\text {floor }}+U A_{\text {wall-zone II }}+U A_{\text {ceiling }}+U A_{\text {window }}+U A_{\text {door }}$
$+U A_{\text {infiltration }}$

Table F.8.1 Prototype Total UA Values By Compliance Level and Climate Zone

\begin{tabular}{||l|l|l|l|l|l|l|l|l||}
\hline \hline Level & 1 & 1 & 2 & 2 & 3 & 3 & 4 & 4 \\
\hline Zone & I & I I & I & I I & I & I I & I & I I \\
\hline \hline Smal1 (Slab) UA & 374 & 364 & 426 & 417 & 472 & 464 & 500 & 491 \\
\hline Medium (Sl ab) UA & 446 & 431 & 503 & 491 & 556 & 543 & 588 & 574 \\
\hline Large (Slab) UA & 540 & 530 & 622 & 613 & 693 & 684 & 734 & 724 \\
\hline \hline Smal1 (Craw1) UA & 312 & 303 & 362 & 354 & 406 & 398 & 431 & 422 \\
\hline Medium (Craw1) UA & 392 & 378 & 449 & 437 & 499 & 487 & 528 & 514 \\
\hline Large (Craw1) UA & 483 & 473 & 563 & 554 & 632 & 623 & 670 & 660 \\
\hline \hline
\end{tabular}



APPENDIX G

DETAILED INFORMATION ON PARTICIPATING JURISDICTIONS 
IABLE G.1. WSEC Participants That Did Not Participate in the NWEC

\begin{tabular}{|c|c|c|c|c|c|c|}
\hline Jurisdiction & County & $\begin{array}{l}\text { BPA } \\
\text { Area }\end{array}$ & $\begin{array}{l}\text { Single- } \\
\text { Family } \\
\text { Home }\end{array}$ & $\begin{array}{l}1991 \% \\
\text { Housing }\end{array}$ & Contact & Phone \\
\hline Island County & Island & PSA & 525 & $2.212 \%$ & Len Eserhut & 206/679-7308 \\
\hline Clallam County & Clallam & PSA & 283 & $1.192 \%$ & Ed Sophie & $206 / 452-0470$ \\
\hline Cowlitz County & Cowlitz & LCA & 128 & $0.539 \%$ & Gene Schneider & 206/423-9987 \\
\hline Port Angeles & Clallam & PSA & 90 & $0.379 \%$ & Larry Romig & 206/457-0411 \\
\hline $\begin{array}{l}\text { Walla Walla } \\
\text { County }\end{array}$ & Walla Walla & SRA & 88 & $0.371 \%$ & Larry Lent & $509 / 527-3285$ \\
\hline Wenatchee & Chelan & UCA & 64 & $0.270 \%$ & Dale C. Kinkade & $509 / 664-5986$ \\
\hline Mount Vernon & Skagit & PSA & 163 & $0.687 \%$ & C. Joe Natola & $206 / 336-6214$ \\
\hline Stevens County & Stevens & UCA & 141 & $0.594 \%$ & W.D. Jones & $509 / 684-8310$ \\
\hline Jefferson County & Jefferson & PSA & 292 & $1.230 \%$ & Michael Ajax & 206/385-9141 \\
\hline $\begin{array}{l}\text { Mason County } \\
\text { (Pretest) }\end{array}$ & Mason & PSA & 424 & $1.786 \%$ & Dan Fitchitt & $206 / 427-9670$ \\
\hline Asotin County & Asotin & UCA & 39 & $0.164 \%$ & Jim Martin & $509 / 243-4120$ \\
\hline Mercer Island & King & PSA & 37 & $0.156 \%$ & Bill Price & $206 / 236-5300$ \\
\hline Skamania County & Skamania & LCA & 35 & $0.147 \%$ & Dean A. Nygaard & $509 / 427-5141$ \\
\hline Mountlake Terrace & Snohomish & PSA & 31 & $0.131 \%$ & Ron Demars & $206 / 776-1161$ \\
\hline Oak Harbor & Island & PSA & 29 & $0.122 \%$ & Jim Koepke & 206/679-5551 \\
\hline Friday Harbor & San Juan & PSA & 23 & $0.097 \%$ & James E. Hodges & $206 / 378-2390$ \\
\hline Chelan & Chelan & UCA & 21 & $0.088 \%$ & Cliff Burdick & $509 / 682-5722$ \\
\hline West Richland & Benton & SRA & 21 & $0.088 \%$ & Wayne Hoffman & $509 / 967-3431$ \\
\hline Walla Walla City & Walla Walla & SRA & 19 & $0.080 \%$ & Bob Martin & $509 / 527-4386$ \\
\hline Sequim & Clallam & PSA & 24 & $0.101 \%$ & Jeannine Blair & 206/683-4908 \\
\hline East Wenatchee & Douglas & UCA & 16 & $0.067 \%$ & Nick Wiltz & 509/884-1796 \\
\hline Selah & Yakima & SRA & 11 & $0.046 \%$ & Joe Henne & 509/697-9799 \\
\hline Whitman County & Whitman & UCA & 4 & $0.017 \%$ & Kirk Moors & $509 / 397-3546$ \\
\hline \multicolumn{7}{|c|}{$\begin{array}{l}\text { LCA }=\text { Lower Columbia Area } \\
\text { PSA }=\text { Puget Sound Area } \\
\text { SRA }=\text { Snake River Area } \\
\text { UCA }=\text { Upper Columbia Area } \\
\text { Pretest: some jurisdictions were tested in a pretest phase of the analysis. }\end{array}$} \\
\hline
\end{tabular}


TABLE G.2. WSEC Participants That Did Participate in the NWEC

\begin{tabular}{|c|c|c|c|c|c|c|}
\hline Jurisdiction & County & $\begin{array}{l}\text { BPA } \\
\text { Area }\end{array}$ & $\begin{array}{l}\text { Single- } \\
\text { Family } \\
\text { Home }\end{array}$ & $\begin{array}{l}1991 \% \\
\text { Housing }\end{array}$ & Contact & Phone \\
\hline Clark County & Clark & LCA & 1963 & $8.269 \%$ & Larry Collins & 206/699-2011 \\
\hline Spokane County & Spokane & UCA & 1113 & $4.689 \%$ & Randy Vissia & $509 / 456-3675$ \\
\hline Lacey (Pretest) & Thurston & PSA & 263 & $1.108 \%$ & John Neff & 206/491-5642 \\
\hline Blaine & Whatcom & UCA & 66 & $0.278 \%$ & Ray Chenoweth & $206 / 332-8311$ \\
\hline Franklin County & Franklin & SRA & 57 & $0.240 \%$ & Darryl Brown & $509 / 545-3523$ \\
\hline Grays Harbor County & Grays Harbor & PSA & 50 & $0.211 \%$ & Al Rhoades & $206 / 249-5579$ \\
\hline Redmond (Pretest) & King & PSA & 95 & $0.400 \%$ & Sue Simpson & 206/556-2434 \\
\hline Pullman & Whitman & UCA & 33 & $0.139 \%$ & James Hudak & $509 / 334-4555$ \\
\hline Cheney & Spokane & UCA & 19 & $0.080 \%$ & Cliff Furguson & $509 / 235-7244$ \\
\hline Omak & Okanogan & UCA & 4 & $0.017 \%$ & Wayne Keith & $509 / 826-1170$ \\
\hline Columbia County & Columbia & SRA & 1 & $0.004 \%$ & Kim Lyonnais & $509 / 382-4676$ \\
\hline \multicolumn{7}{|c|}{$\begin{array}{ll}\text { LCA }=\text { Lower Columbia Area } & \text { PSA }=\text { Puget Sound Area } \\
\text { SRA }=\text { Snake River Area } & \text { UCA }=\text { Upper Columbia Area } \\
\text { Pretest: } & \text { some jurisdictions were tested in a pretest phase of the analysis. }\end{array}$} \\
\hline
\end{tabular}

IABLE G.3. Non-Participant Jurisdictions That Did Participate in the NWEC

\begin{tabular}{|c|c|c|c|c|c|c|}
\hline Jurisdiction & County & $\begin{array}{l}\text { BPA } \\
\text { Area }\end{array}$ & $\begin{array}{l}\text { Single- } \\
\text { Family } \\
\text { Home }\end{array}$ & $\begin{array}{l}1991 \% \\
\text { Housing }\end{array}$ & Contact & Phone \\
\hline King County & King & PSA & 2727 & $11.488 \%$ & Pete Stewart & $206 / 296-6748$ \\
\hline Pierce County & Pierce & PSA & 2250 & $9.478 \%$ & Gerald E. Grave & $206 / 591-7148$ \\
\hline Pend Oreille County & Pend Oreille & UCA & 45 & $0.190 \%$ & Bob Pelleberg & $509 / 447-4821$ \\
\hline Arlington & Snohomish & PSA & 59 & $0.249 \%$ & Dave Anderson & 206/435-0724 \\
\hline Winslow & Kitsap & PSA & 34 & $0.143 \%$ & Larry Skinner & $206 / 842-5741$ \\
\hline Lincoln County & Lincoln & UCA & 12 & $0.051 \%$ & Terry Goodman & $509 / 725-7911$ \\
\hline Quincy & Grant & UCA & 4 & $0.017 \%$ & Willy Hill & $509 / 787-4131$ \\
\hline \multicolumn{7}{|c|}{$\begin{array}{ll}\text { LCA }=\text { Lower Columbia Area } & \text { PSA }=\text { Puget Sound Area } \\
\text { SRA }=\text { Snake River Area } & \text { UCA }=\text { Upper Columbia Area } \\
\text { Pretest: } & \text { some jurisdictions were tested in a pretest phase of the analysis. }\end{array}$} \\
\hline
\end{tabular}


TABLE G.4. Non-Participant Jurisdictions That Did Not Participate in any Previous Program

\begin{tabular}{||l|l|l|r|r|l|l||}
\hline \multicolumn{1}{|c|}{ Jurisdiction } & \multicolumn{1}{|c|}{ County } & $\begin{array}{c}\text { BPA } \\
\text { Area }\end{array}$ & $\begin{array}{r}\text { Single- } \\
\text { Family } \\
\text { Home }\end{array}$ & $\begin{array}{c}1991 \% \\
\text { Housing }\end{array}$ & \multicolumn{1}{|c|}{ Contact } & Phone \\
\hline \hline Whatcom County & Whatcom & UCA & 511 & $2.153 \%$ & Carol Oberton & $206 / 676-6907$ \\
\hline Yakima County & Yakima & SRA & 374 & $1.576 \%$ & Dave Saunders & $509 / 575-4163$ \\
\hline Bothell & King & PSA & 73 & $0.308 \%$ & Jim Roshak & $206 / 486-2768$ \\
\hline Sea Tac & King & PSA & 11 & $0.046 \%$ & Dan Simon & $206 / 878-9100$ \\
\hline Prosser & Benton & SRA & 5 & $0.021 \%$ & Tom McGough & $509 / 786-7383$ \\
\hline $\begin{array}{l}\text { LCA }=\text { Lower Columbia Area } \\
\text { PSA }=\text { Puget Sound Area } \\
\text { SRA }=\text { Snake River Area } \\
\text { UCA = Upper Columbia Area } \\
\text { Pretest: some jurisdictions were tested in a pretest phase of the analysis. }\end{array}$ \\
\hline
\end{tabular}


. 
APPENDIX H

PROCESS SURVEY QUESTIONNAIRES 


\section{APPENDIX H}

\section{PROCESS SURVEY QUESTIONNAIRES}

Two questionnaires were used: one for those who participated in the Washington State Energy Code Program and one for those who did not participate in the program. Copies of both questionnaires are provided in this appendix.

H. 1 


\section{Washington State Energy Code Program Participant Interview Guide}

ID\# :

Interviewer:

Date:

PLEASE VERIFY THE FOLLOWING INFORMATION:

Jurisdiction:

Contact:

Address:

Phone:

Fax:

Utility(ies):

Program start date:

BPA area:

PLEASE NOTE:

WE ARE FOCUSING OUR EVALUATION ON THE EFFECT OF THE WSEC PROGRAM ON CODE COMPLIANCE IN SINGLE-FAMILY, ELECTRICALLY HEATED DWELLINGS AND WOULD LIKE YOUR ANSWERS TO REFLECT YOUR EXPERIENCE WITH THESE HOMES. IF THERE ARE IMPORTANT THINGS HE SHOULD KNOH ABOUT MULTI-FAMILY BUILDINGS, HOHEYER, PLEASE POINT THESE OUT.

THE FOLLOWING QUESTIONS WILL BE DISCUSSED DURING THE INTERVIEW:

START UP

1. Did your contract process with WSEO go smoothly (for example, in terms of time/term, payment, training)? If not, why?

2. Do you have any suggestions for how the contracting process might be improved?

3. If the WSEC funding was allocated to your local government or general fund, did your organization actually receive the funds for implementation of the code? If not has this created any problems?

4. Has anyone from WSEO assisted you in person with implementation of the program?

$$
\text { H.2 }
$$


Did the assistance take place

in your office, or

in the field?

Was the assistance helpful?

\section{NWEC INVOLVEMENT}

5. Did you participate in the NWEC program?

If yes:

5.a. How has the NWEC experience helped you implement the new code?

5.b. Have you experienced any problems related to confusion between the NWEC and the WSEC? Have these problems been resolved?

TRAINING AND MATERIALS

Training and materials refers to any activities that provide you or other staff with general information on the code or the WSEC program. It is usually done on a group basis.

6. How many people did you expect to train with your WSEC training budget? How many have been trained to date?

7. There are 5 different training classes offered as part of the WSEC program. Which of these have you or other staff in your office attended?

code overview site inspection ventilation plan review

component performance

7.a. What is your opinion of the training and what kind of feedback have you received from others? 
8. Do you believe that you and other code officials at your agency received sufficient training and support through the WSEC program to enforce the new code, or do you think additional training or some other form of support should be provided?

9. Do you have any suggestions for improving the training program? (i.e., more of the same or additional classes?)

TECHNICAL ASSISTANCE

Technical assistance can be described as any specific technical information or assistance on the code. It is usually done on a one-on-one basis.

10. In what ways has the technical assistance provided by WSEO been useful? Is the level of technical assistance sufficient or could you use more?

11. Have you called any of the hotlines for material or information? (yes/no) If yes:

11.a. Which hotline(s) did you call? TA4U, ICBO, other

11.b. Is it typically easy to get through to the hotline when you need assistance? How long has it taken to get an answer?

11.c. How useful has the information been?

If no:

11.d. Where do you obtain code information when you need it?

12. What is your overall impression of the technical assistance hotlines? 
13. How do you provide feedback to WSEO on the quality of the hotline service and/or other aspects of code implementation?

UTILITY INVOLVEMENT

14. Has your local utility provided technical assistance with previous energy code compliance and training programs or with the WSEC program?

If yes:

14.a. Describe how they helped in previous programs.

14.b. Describe how they have helped with the WSEC program.

14.c. In what ways has utility involvement added to the success of the programs?

If no:

14.d. Do you believe their assistance would enhance your code implementation efforts?

DOCUMENTATION

15. What types of documentation does the utility require you to provide when requesting them to make payments?

15.a. In your opinion, are these requirements reasonable?

16. Have you experienced any problems or frustrations in completing or submitting the monthly reports for WSEO? How long does it take to complete the paperwork?

17. Do you have any suggestions for improving the reporting and record keeping requirements of the program? 
18. How have builders responded to the new code? Do they understand it?

19. What are the main recurring compliance problems that builders seem to have?

19.a. Is the problem due to:

builders do not understand some aspect of the code builders are generally not willing to comply builders unable to get the supplies they need other, please explain

20. What feedback have you received from builders on the training program provided on construction techniques and thermal standards?

21. What feedback have you received from suppliers on the training program provided on the code and materials?

\section{ENFORCEMENT}

22. Please describe the process you use to check and verify builder compliance with the WSEC including:

22.a. plan checking

22.b. number of on-site inspections you make per home

22.c. what you inspect for during each visit

22.d. What you do if you find something that does not comply

22.e. how you verify if corrective actions have been taken 
23. What procedure do you follow in determining compliance on your final inspection?

24. Has the WSEC placed any significant burdens on you or your staff during enforcement in the field? For example, in terms of

time
paperwork
other (please describe) callbacks training (on site)

24.a. Is anything being done, either through the program or some other mechanism, to overcome these problems?

24.b. Is there anything additional that could be done to better prepare you for code enforcement?

\section{NETWORKING}

25. Are you exchanging information and experiences, either formally or informally, with other WSEC jurisdictions?

If yes:

25.a. Was the group organized through ICBO or AWC?

25.b. How often do you meet/talk?

25.c. How many people typically attend?

25.d. Have you found this process to be effective in helping implement the new code?

25.e. Do you have any suggestions for improving this process?

If no: 
25.f. Do you believe it would be useful for you to participate in some sort of networking arrangement? (why/why not?)

25.g. If you have considered participating in a network, why have you decided not to participate? (i.e., never been approached, don't have time, don't think it's worthwhile.)

CLOSE

26. In your opinion, what are the most important benefits of participating in the WSEC program?

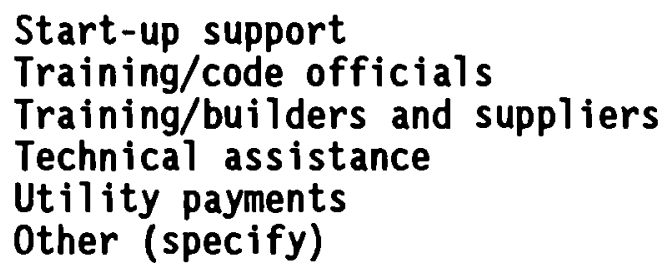

27. What are the biggest drawbacks of participating in the WSEC program?

28. The following factors may impact the overall success of any energy code implementation and enforcement effort. Please score the following factors on a scale from 1 to 5 (1=10w importance, 5=very important) according to the ir impact on successful energy code implementation and enforcement. Briefly explain your score.

Score

Utility support:

Jurisdictional support:

Building activity level:

29. Past experience with energy codes:

energy code training and assistance programs:

Other (explain): 
29.a. We would also like to know how you think these factors have affected the success (or lack of success) of implementing the WSEC. Please explain.

Utility support:

Jurisdictional support:

Building activity level:

29.b. Past experience with energy codes:

WSEC program:

Other (explain):

30. Is there any issue of importance that we might have missed in our questions today that you believe may impact the WSEC program's success?

31. Is there anything that you would like to mention about how to improve any aspect of the WSEC program implementation?

32. Is there anything special that you would like to see from this evaluation? 


\section{Washington State Energy Code Program Non-Participants}

Interview Guide

ID\# :

Interviewer:

Date:

Jurisdiction:

Contact:

Address :

Phone:

Fax:

Utility(ies):

Program start date:

BPA area:

PLEASE NOTE:

WE WOULD LIKE YOUR ANSWERS TO REFLECT YOUR EXPERIENCE WITH SINGLE-FAMILY, ELECTRICALLY HEATED DWELLINGS. IF THERE ARE IMPORTANT THINGS WE SHOULD KNOW ABOUT MULTI-FAMILY BUILDINGS, HOWEVER, PLEASE POINT THESE OUT.

THE FOLLOWING QUESTIONS WILL BE DISCUSSED DURING THE INTERVIEW:

START UP AND WSEC PREPARATIONS

1. If applicable, how long has your jurisdiction been participating in the NWEC program?

2. Are you currently enforcing the WSEC, including ventilation requirements, for electric and/or gas homes?

a. Yes.

b. No.

i. What code are you enforcing?

ii. Why has your jurisdiction decided not to adopt the WSEC?

3. Has anyone from WSEO contacted you about the opportunity to participate in the WSEC program? (yes/no) 
4. Does your jurisdiction plan to join the WSEC program?
a. Yes. When?
b. No. Why have you decided not to?

5. In your opinion, what might be the most important benefits of participating in the WSEC program?

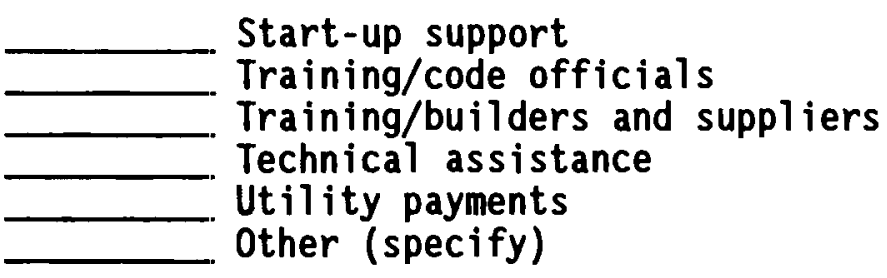

6. What are the possible drawbacks of participating in the WSEC program?

7. If applicable, have you experienced any problems related to confusion between the NWEC and the WSEC? Have these problems been resolved?

\section{TRAINING}

8. Have you or your staff attended any of the training sessions offered by WSEO to help you prepare for WSEC implementation? (yes/no)

\section{If yes:}

a. There are 5 different training classes offered as part of the WSEC program. Which of these have you or other staff in your office attended?

$$
\text { code overview }
$$
site inspection ventilation plan review component performance

b. What is your opinion of the training and what kind of feedback have you received from others?

9. Do you have any suggestions for improvement(s) to the training program? 
TECHNICAL ASSISTANCE

10. Have you called any of the WSEC hotlines for material or information? (yes/no)

If yes:

a. Which hotline(s) did you call? _TA4U___ ICBO _other

b. Is it typically easy to get through to the hotline when you need assistance? Hoe long has it taken to get an answer?

c. How useful has the information been?

If no:

d. Where do you obtain code information when you need it?

11. What is your overall impression of the technical assistance hotlines?

\section{UTILITY INVOLVEMENT}

12. Does your local utility provide technical assistance and/or training on energy code compliance?

If yes:

a. Describe how they help.

b. Is this assistance part of any formal program (e.g., SGC program)?

c. In what ways has utility involvement added to the success of the programs?

If no:

d. Do you believe their assistance would enhance your code implementation efforts? 
13. Are you working with someone at the utility to help you with the tracking? If yes:

a. Has working with the utility been helpful?

b. Have you worked with anyone from the utility to develop a way to handle the utility payments the new code requires?

c. Are you satisfied with the utility's assistance?

If no:

d. Would this sort of assistance be helpful?

\section{BUILDERS/SUPPLIERS}

14. How have builders responded to the new code? Do they understand it?

15. What are the main recurring compliance problems that builders seem to have?

a. Is the problem due to:

builders do not understand some aspect of the code builders are generally not willing to comply builders are unable to get the supplies they need other, please explain

16. Have you received any feedback from local builders on training they have received on construction techniques and thermal standards? Who provided them with this training?

17. Have you received any feedback from local suppliers on training they have received on energy codes and materials? Who provided them with this training? 


\section{ENFORCEMENT}

18. Please describe the process you use to check and verify builder compliance with the energy code including:
a. plan checking
b. number of on-site inspections you make per home
c. what you inspect for during each visit
d. What you do if you find something that does not comply
e. how you verify if corrective actions have been taken

19. What procedure do you follow in determining compliance on your final inspection?

\section{NETWORKING}

20. Are you exchanging information and experiences, either formally or informally, with other NWEC or WSEC jurisdictions?

If yes:

a. Is this a formalized process or do you correspond only with certain other persons or jurisdictions?

b. How often do you meet/talk?

c. Have you found this process to be effective?

d. Do you have any suggestions for improving this process?

If no:

e. Do you believe it would be useful for you to participate in some sort of networking arrangement? (why/why not?)

f. Have you investigated this in the past?

\section{H. 14}


g. Why have you decided not to participate? (e.g., never been approached, don't have time, don't think it's worthwhile)

CLOSE

21. The following factors may impact the overall success of any energy code implementation and enforcement effort. Please score the following factors on a scale from 1 to 5 ( $1=$ low importance, 5=very important) according to the ir impact on successful energy code implementation and enforcement. Briefly explain your score.

Score

Utility support:

Jurisdictional support:

Building activity level:

22. Past experience with energy codes:

Energy code training and assistance programs:

Other (explain):

23. Is there any issue of importance that we might have missed in our questions today that you believe may impact the WSEC program's success?

24. Is there anything special that you would like to see from this evaluation? 
. 


\section{APPENDIX I}

DETAILED FINDINGS OF THE PROCESS EVALUATION 



\section{APPENDIX I}

\section{DETAILED FINDINGS OF THE PROCESS EVALUATION}

This appendix presents details of the process evaluation findings. Three groups of findings are presented: 1) assessments of how well various Program components were performing, 2) assessments of the role of other nonprogrammatic factors in code implementation, and 3) impacts of the Program as a whole on successful code implementation.

\section{I.1 PROGRAM COMPONENT ASSESSMENTS}

The following sections discuss how well the various components of the Program were performing. The components considered were funding, start-up support and training, on-going training and support, and technical assistance. Most of these components involved the code officials, but where they involved others, such as builders, these results are discussed. We also include a discussion of institutional issues that affect Program success.

\section{I.1.1 Funding and Payments}

All but one jurisdiction said that their department did receive the funds intended for code implementation. The one jurisdiction that didn't receive the funding stated that the funds were allocated to the city's general fund and were never allocated to their department, creating problems for their department in terms of funding shortfalls and frustrations. Since this situation happened in only one case, it was not considered to be a general problem.

Only one-fourth of the Program jurisdiction code officials and none of the non-participating jurisdiction officials believed that payments to builders were important for WSEC implementation success. A few expressed concerns about the paperwork burden on the jurisdiction associated with these payments. A prevalent attitude among several of these code officials was that the builder payments might be inequitable and ineffective. Typical comments included

- "It was a hassle to track down social security numbers for builder payments."

- $\quad$ "Payments should be dedicated to building departments, and not to each particular home. Payments should be uniform and balanced, not biased towards electrically-heated homes."

- "We shouldn't be bribing builders to build what they are required to by law. I and many others believe this money should be spent some other way that gains more widespread benefit, like maybe providing assistance to retrofit homes." 
One other issue about builder payments emerged during our data collection. In a few cases, utilities had some concerns caused by the lag between when a home under construction was hooked up for electrical service and when it was qualified and the builder received the payment. The often long lag (as much as a year) had caused a few utilities to question whether the homes were ever built to comply with the WSEC. This appeared to be more a problem of perceptions than an indicator of any fundamental problems with the Program or WSEC.

\section{I.1.2 Code Official Start-up Training and Support}

All but three respondents stated that they had received start-up support, and one of these said that they didn' $t$ receive it because they didn' $t$ need it and were able to get their questions answered over the phone. The other two code officials were asked if this sort of assistance would have been helpful and both said it would have. One of these jurisdictions had the following to say:

- "We certainly could have used this assistance in the office to get the computer system up and running. We were mailed the computer system and told to call with questions. WSEO finally had to come out once the Program was underway and it was clear that we were in serious need of help."

Twenty-five percent of the jurisdictions said they received training in the office only. All jurisdictions that received start-up support were asked if the support was useful. Ninety-one percent of the jurisdictions stated that the assistance was very helpful; six percent said it was somewhat helpful; and only one code official said it was not helpful.

The respondents who stated that the Program was only "somewhat helpful" had comments such as these:

- "It took a while for [WSEO] to be helpful because they weren't that familiar with the computer system, but they did their best."

- $\quad$ "Someone did visit our office but we would have preferred more interaction up front. Our liaison person did not visit until after the first quarter of Program operation."

\section{I.1.3 On-Going Energy Code Training}

Table I.l presents an overview of data indicating which training classes were attended. Code overview training was the most widely attended training class, except for group A jurisdictions (WSEC participants, no NWEC experience). Group A respondents attended the ventilation training most often; code overview was the second most often attended class for this group. There was no significant difference in the type or amount of training received by Program participant and non-participant jurisdictions. Prior NWEC experience also had no consistent effect on the amount of training received by a jurisdiction. 
IABLE I.1. Training Classes Code Officials Report They Attended

\begin{tabular}{||l|c|c|c|c||}
\hline \multirow{2}{*}{ Training Sessions } & \multicolumn{2}{|c|}{$\begin{array}{c}\text { WSEC Program } \\
\text { Participants }\end{array}$} & \multicolumn{2}{c|}{$\begin{array}{c}\text { WSEC Program Non- } \\
\text { Participants }\end{array}$} \\
\cline { 2 - 5 } & $\begin{array}{c}\text { Group A } \\
\text { (non-NWEC) }\end{array}$ & $\begin{array}{c}\text { Group B } \\
\text { (NWEC) }\end{array}$ & $\begin{array}{c}\text { Group C } \\
\text { (NWEC) }\end{array}$ & $\begin{array}{c}\text { Group D } \\
\text { (non-NWEC) }\end{array}$ \\
\hline Any (of the following) & $95 \%$ & $89 \%$ & $100 \%$ & $100 \%$ \\
\hline Code overview & $82 \%$ & $64 \%$ & $100 \%$ & $100 \%$ \\
\hline Plan review & $73 \%$ & $64 \%$ & $71 \%$ & $60 \%$ \\
\hline Site inspection & $61 \%$ & $45 \%$ & $57 \%$ & $60 \%$ \\
\hline Component performance & $64 \%$ & $36 \%$ & $71 \%$ & $60 \%$ \\
\hline Ventilation & $91 \%$ & $45 \%$ & $57 \%$ & $60 \%$ \\
\hline \hline $\mathrm{n}=$ & 22 & 9 & 7 & 5 \\
\hline \hline
\end{tabular}

Code officials were also asked for their overall opinion of the WSEC training received from the state and any feedback from others on the training. Responses to this question are summarized in Table I.2

TABLE 1.2. Code Officials' Overall Opinion of the WSEC Training Received from the State

\begin{tabular}{||l|c|c|c|c||}
\hline \hline \multirow{2}{*}{$\begin{array}{l}\text { Opinion of WSEC } \\
\text { Training and Feedback } \\
\text { from Others }\end{array}$} & \multicolumn{2}{|c|}{$\begin{array}{c}\text { WSEC Program } \\
\text { Participants }\end{array}$} & \multicolumn{2}{|c|}{$\begin{array}{c}\text { WSEC Program Non- } \\
\text { Participants }\end{array}$} \\
\cline { 2 - 5 } & $\begin{array}{c}\text { Group A } \\
\text { (non-NWEC) }\end{array}$ & $\begin{array}{c}\text { Group B } \\
\text { (NWEC) }\end{array}$ & $\begin{array}{c}\text { Group C } \\
\text { (NWEC) }\end{array}$ & $\begin{array}{c}\text { Group D } \\
\text { (non-NWEC) }\end{array}$ \\
\hline Very good/excellent & $73 \%$ & $80 \%$ & $71 \%$ & $60 \%$ \\
\hline Good & $18 \%$ & $10 \%$ & $14 \%$ & $20 \%$ \\
\hline Poor & $9 \%$ & $10 \%$ & $14 \%$ & $20 \%$ \\
\hline \hline$n=$ & 22 & 10 & 7 & 5 \\
\hline \hline
\end{tabular}

Although the majority of respondents answered that the training was "good" or better, many had additional comments or caveats. The most common comments included the following:

- "There is a need for classes that address different skill levels of code officials."

- We need more complex training."

- "Classes should be offered at more convenient locations." 
Official participation in the Program seemed to translate into higher ratings for the training. For example, $91 \%$ of non-NWEC jurisdiction respondents in the Program rated the training as "good" or better, whereas the share was only $80 \%$ of comparable non-Program jurisdictions. Whether or not the jurisdiction was in the NWEC appeared to have no significant effect on the training program ratings.

Over half the respondents said that they had received no feedback from builders on training provided by the state or anyone else. Many doubted that builders had attended any training at all.

of the respondents who received feedback on training from builders, most had heard favorable comments. Few respondents stated that feedback from builders was negative. Table I.3 presents the results of builder feedback on training by code experience group. Because of the small number of respondents who reported builder feedback, however, it was difficult to draw general conclusions based on differences between code experience groups.

TABLE I.3. Builder Response to Training Provided by WSEO (according to code officials interviewed)

\begin{tabular}{||l|c|c|c|c||}
\hline \multirow{2}{*}{$\begin{array}{l}\text { Builder Response to } \\
\text { WSEO Training }\end{array}$} & \multicolumn{2}{|l|}{$\begin{array}{l}\text { WSEC Program } \\
\text { Participants }\end{array}$} & $\begin{array}{l}\text { WSEC Program Non- } \\
\text { Participants }\end{array}$ \\
\cline { 2 - 5 } & $\begin{array}{c}\text { Group A } \\
\text { (non-NWEC) }\end{array}$ & $\begin{array}{c}\text { Group B } \\
\text { (NWEC) }\end{array}$ & $\begin{array}{c}\text { Group C } \\
\text { (NWEC) }\end{array}$ & $\begin{array}{c}\text { Group D } \\
\text { (non-NWEC) }\end{array}$ \\
\hline Favorable & $88 \%$ & $100 \%$ & $100 \%$ & $50 \%$ \\
\hline Unfavorable & $12 \%$ & $0 \%$ & $0 \%$ & $50 \%$ \\
\hline \hline$n=$ & 8 & 3 & 3 & 2 \\
\hline
\end{tabular}

A comment consistent across all code official groups was that it was very difficult to get builders to participate in any kind of training program. Others noted that training was not reaching the subcontractors who actually installed or constructed specific house components that must comply with the code. Prime contractors who attended the training did not necessarily pass along what they had learned to subcontractors and crews. This lack of builder interest in training and failure to reach the necessary personnel was frustrating to a number of code officials who believed builders desperately needed training. Typical code official comments about builders and the ir training included the following:

- $\quad$ "The code requires more technical support for one-time builders. They just take too much time and effort, and we don't have enough staff to handle them."

- "[The WSEC leads to m]ore questions from builders which take time to address." 
A significant consequence of these inadequacies was that the WSEC increased the amount of de facto training done by the code officials. As in the above comments, several jurisdictions noted that they spent a considerable amount of time explaining how to comply with the code. It appeared that to the builders and their subcontractors it was more economical to fail to comply, be cited, and have the inspector explain how to comply rather than attend formal training courses. This placed a considerable burden on the code officials.

When asked about feedback received from suppliers on energy code training, only two code officials had received any, and most doubted that suppliers had received any training. Overall, respondents stated that builders now seemed to be getting the materials they needed and there was no longer much need for supplier training. One respondent who had received feedback from a supplier stated that the supplier thought the training session was great because he could sell materials there, and the other respondent said that the supplier indicated that the training was very good.

\section{I.1.4 Technical Assistance}

Although the majority of code officials thought the assistance was useful, there were some differences across groups of code officials. Summary results are presented in Table I.4.

TABLE I.4. Reported Usefulness of WSEC Technical Assistance

\begin{tabular}{||l|c|c|c|c||}
\hline \hline $\begin{array}{l}\text { Usefulness of Technical } \\
\text { Assistance }\end{array}$ & \multicolumn{2}{|c|}{$\begin{array}{c}\text { WSEC Program } \\
\text { Participants }\end{array}$} & \multicolumn{2}{|c|}{$\begin{array}{c}\text { WSEC Program Non- } \\
\text { Participants }\end{array}$} \\
\cline { 2 - 5 } & $\begin{array}{c}\text { Group A } \\
\text { (non-NWEC) }\end{array}$ & $\begin{array}{c}\text { Group B } \\
\text { (NWEC) }\end{array}$ & $\begin{array}{c}\text { Group C } \\
\text { (NWEC) }\end{array}$ & $\begin{array}{c}\text { Group D } \\
\text { (non-NWEC) }\end{array}$ \\
\hline Useful & $95 \%$ & $82 \%$ & $100 \%$ & $50 \%$ \\
\hline Not usefu1 & $5 \%$ & $18 \%$ & 0 & $50 \%$ \\
\hline \hline$n=$ & 21 & 11 & 7 & 4 \\
\hline
\end{tabular}

Unlike the results for training, there was no apparent correlation between Program participation and code official assessment of the technical assistance. NWEC experience also did not appear to have a consistent effect on the ratings.

The large majority of respondents, except those with neither NWEC or Program experience (group D), stated that the technical assistance provided by WSEO had been usefu1. Some of the positive responses include these:

- "The technical assistance has been very helpful. We have even referred contractors to the hot line as a back up resource."

- "The technical assistance and training have been the key to our jurisdiction's success in getting up to speed on the code." 
- "Every time I've needed help I've gotten it quickly. The hotline people even send me additional materials when I need it."

\section{I.1.5 Institutional Issues}

Area office Program contacts were obtained from Bonneville headquarters staff. We had intended to interview each area office contact, however, there was no contact in one of the area offices and another area office was being handled by Bonneville headquarters. The two area offices that provided the majority of feedback on the Program and area office operations were the Snake River Area Office and the Puget Sound Area Office. The other area offices were not involved in the Program to any degree.

Bonneville and WSEO appeared to have differing views of the proper role of the Bonneville area offices in the WSEC program. According to Bonneville, the area offices had no mandate or authority to become involved with the jurisdictions: that is the role of WSEO. According to Bonneville staff: "The area offices should only become involved if there is a problem and a jurisdiction contacts the Bonneville area office. This just hasn't happened so far." An area office representative said that their only role was to accompany WSEO on some site inspections for quality assurance purposes and that their only involvement with jurisdictions was during transition from the NWEC to the WSEC Program.

WSEO, on the other hand, believed the Bonneville area offices were not as involved in the Program as was originally agreed upon, except in the case of one area office. According to the WSEO, the Bonneville area offices were supposed to provide the link with local governments and utilities in the ir area. Only one Bonneville area office attended the periodic meetings set up to discuss the progress of the WSEC Program and current issues.

WSEO believed that if the Bonneville area offices were more involved in the Program some of the implementation problems could be solved. For example, builders were having a problem getting their payments from utilities in one county and WSEO believed that the Bonneville area office, due to its relationship with utilities, could have helped solve the problem.

Regarding utility involvement, WSEO and Bonneville staff noted that added utility support in the form of technical assistance would be beneficial to the Program.

\section{I.2 EFFECTS OF OTHER FACTORS}

We investigated several factors that were not Program components, but might have impacts on successful code implementation. The factors that we examined were prior code program experience, utility support, local government support, jurisdiction networks, and building activity level.

\section{I.2.1 Impact of Past Energy Code Experience on Implementation of the WSEC}

Program participants with prior NWEC experience were asked if and how the NWEC helped them implement the WSEC. Eighty percent said that

\section{I.6}


participating in the NWEC did help them implement the WSEC; $20 \%$ said that it had no influence. Representative comments from jurisdictions about their NWEC experience included these:

- "Our NWEC experiences made for a smooth transition to the WSEC, especially since many of the forms we use remained the same."

- "Builders were prepared for the requirements."

- "There is not much difference between the NWEC and the WSEC so we didn't have to learn things over."

- $\quad$ Because of the NWEC we had received training and were technically up to speed on the new code since the two codes were so similar."

NWEC participants were also asked if they experienced any problems related to confusion between the NWEC and WSEC. Table I.5 shows that findings depend on whether or not the jurisdiction was in the Program.

IABLE I.5. Frequency of Problems Related to Confusion Between the WSEC and NWEC - Prior NWEC Jurisdictions

\begin{tabular}{||l|c|c||}
\hline $\begin{array}{l}\text { Problems Related to } \\
\text { Confusion Between NWEC and } \\
\text { WSEC }\end{array}$ & $\begin{array}{c}\text { Group B } \\
\text { WSEC Program } \\
\text { Participants }\end{array}$ & $\begin{array}{c}\text { Group C } \\
\text { WSEC Program } \\
\text { Non-participants }\end{array}$ \\
\hline Significant problems & $10 \%$ & $71 \%$ \\
\hline Only minor problems & $40 \%$ & $29 \%$ \\
\hline No problems & $50 \%$ & 0 \\
\hline $\mathrm{n}=$ & 10 & 7 \\
\hline
\end{tabular}

The following comments summarized problems related to confusion between the two codes:

- "Builders had lots of problems related to the switch over to the WSEC code mainly due to the fact that they were still having problems understanding the NWEC."

- "At first we had significant problems because BPA and the utilities were not clear on interpretations of the code."

- "We had problems at first understanding the differences between the two codes."

Ratings of the importance of prior energy code experience in implementing new energy codes supported the preceding findings. On a scale from 1 (unimportant) to 5 (very important), Program jurisdictions that participated in the NWEC gave prior experience an importance rating of 4.0, whereas non-NWEC jurisdictions gave it a rating of only 2.9 . 
We also examined whether participation in the SGC program appeared to have any effects on perceptions about the WSEC and the Program and impacts. No discernible effects were apparent. The number of jurisdictions indicating that they were involved in the SGC, however, was small and inadequate to allow drawing definitive conclusions.

\section{I.2.2 Utility Support}

Code officials were asked for their assessment of the importance of utility support. Code officials scored the importance of utility support on a scale from 1 (unimportant) to 5 (very important). The scores are distributed as shown in Table I.6.

TABLE 1.6. Code Officials' Assessment of Importance of Utility Support

\begin{tabular}{||l|c|c|c|c||}
\hline \multirow{2}{*}{ Score } & \multicolumn{2}{|c|}{ WSEC Program Participants } & \multicolumn{2}{|c|}{$\begin{array}{c}\text { WSEC Program Non- } \\
\text { Part icipants }\end{array}$} \\
\cline { 2 - 5 } & $\begin{array}{c}\text { Group A } \\
\text { (non-NWEC) }\end{array}$ & $\begin{array}{c}\text { Group B } \\
\text { (NWEC) }\end{array}$ & $\begin{array}{c}\text { Group C } \\
\text { (NWEC) }\end{array}$ & $\begin{array}{c}\text { Group D } \\
\text { (non-NWEC) }\end{array}$ \\
\hline 5 & 8 & 4 & 3 & 1 \\
\hline 4 & 5 & 2 & 3 & 0 \\
\hline 3 & 3 & 1 & 0 & 2 \\
\hline 2 & 2 & 2 & 1 & 0 \\
\hline 1 & 4 & 0 & 0 & 2 \\
\hline average score & 3.5 & 4 & 4.1 & 2.6 \\
\hline n= & 22 & 9 & 7 & 5 \\
\hline \hline Note: $5=$ very important, $1=$ unimportant & & \\
\hline
\end{tabular}

Average importance scores for jurisdictions receiving utility assistance (4.0) and not receiving assistance (3.1) differed significantly. This demonstrated that, on average, code officials from jurisdictions that received utility assistance considered the benefits more important than did those who currently did not receive this type of support. There was also a significant difference between the average scores of code officials with prior NWEC experience (4.0) and those without (3.3).

Table I.7 shows no correlation between utility support and jurisdiction participation in an energy code implementation and enforcement program. On average, between $36 \%$ and $65 \%$ of jurisdictions received utility support.

The most frequently reported utility support was WATTSUN assistance, typically in the form of providing the jurisdiction with a HATTSUN program output, followed closely by training and technical assistance. Other types of 
utility support mentioned included utility site visits (usually as part of the SGC program) or code interpretations.

\section{TABLE I.7. Utility Support to Jurisdictions}

\begin{tabular}{||c|c|c|c|c||}
\hline \multirow{2}{*}{$\begin{array}{l}\text { Utility Support to } \\
\text { Jurisdictions }\end{array}$} & \multicolumn{2}{|c|}{$\begin{array}{c}\text { WSEC Program } \\
\text { Participants }\end{array}$} & \multicolumn{2}{c|}{$\begin{array}{c}\text { WSEC Program Non- } \\
\text { Participants }\end{array}$} \\
\cline { 2 - 5 } & $\begin{array}{c}\text { Group A } \\
\text { (non-NWEC) }\end{array}$ & $\begin{array}{c}\text { Group B } \\
\text { (NWEC) }\end{array}$ & $\begin{array}{c}\text { Group C } \\
\text { (NWEC) }\end{array}$ & $\begin{array}{c}\text { Group D } \\
\text { (non-NWEC) }\end{array}$ \\
\hline \hline $\begin{array}{l}\text { Utility Provides } \\
\text { Support }\end{array}$ & $65 \%$ & $36 \%$ & $57 \%$ & $40 \%$ \\
\hline $\mathrm{n}=$ & 20 & 11 & 7 & 5 \\
\hline \hline $\begin{array}{l}\text { Types of Support: } \\
\text { Training/tech. }\end{array}$ & $54 \%$ & $50 \%$ & $40 \%$ & $100 \%$ \\
\hline WaTTSUN runs & $46 \%$ & $75 \%$ & $80 \%$ & $50 \%$ \\
\hline Site inspections & $15 \%$ & $0 \%$ & $40 \%$ & $0 \%$ \\
\hline Code interpretations & $0 \%$ & $50 \%$ & $50 \%$ & $0 \%$ \\
\hline $\mathrm{n}=$ & 13 & 4 & 5 & 2 \\
\hline
\end{tabular}

Jurisdictions that received utility support were generally very happy with it. When asked how the assistance added to the success of WSEC implementation, these jurisdictions had the following to say:

- "We are able to qualify homes much quicker with utility involvement (WATTSUN runs)".

- "The utility assists contractors and owner/builders through the SGC program. This has helped get people up to speed on the WSEC and increased code awareness."

- "The utility is supportive of the code and gives it credibility even though they have no formal program."

- "The utility's assistance has been crucial to us in filling the technical assistance need to builders."

- "The utility runs WATTSUN for us which really helps. Also, the more training builders are able to get, the better."

- "The fact that the utility conducts some of the inspections really cuts down on the time we have to spend in the field." 
Respondents who did not receive utility assistance were asked if some sort of utility support would enhance their ability to implement and enforce the WSEC. Forty-five percent said that utility support would or might help; $35 \%$ said it would be a detriment to their efforts; and $20 \%$ said that they simply didn't need it.

The majority of respondents who felt that utility support would or might be useful considered the utility's best role as providing technical assistance or training to builders. A few mentioned that the utility would have to be careful to avoid confusion between WSEC requirements and other utility programs (e.g., SGC). Respondents who said utility support would not be helpful typically believed that utility support could result in confusion between SGC and the state code, conflicting agendas between the state and the utilities, and difficulties caused by utility politics. In addition, some code officials from jurisdictions with prior NWEC experience who participated in the Program said their jurisdiction was doing fine without any utility support.

\section{I.2.3 Local Government Support}

Code officials were asked to assess the importance of city council or internal city management support provided to energy code implementation and enforcement. We asked code officials to score the importance of jurisdiction support on a scale from 1 (unimportant) to 5 (very important). The scores were distributed as shown in Table I.8.

TABLE I.8. Code Officials' Assessment of Importance of Jurisdiction Support

\begin{tabular}{||l|c|c|c|c||}
\hline \multirow{2}{*}{ Score } & \multicolumn{2}{|c|}{ WSEC Program Participants } & \multicolumn{2}{c|}{$\begin{array}{c}\text { WSEC Program Non- } \\
\text { Participants }\end{array}$} \\
\cline { 2 - 5 } & $\begin{array}{c}\text { Group A } \\
\text { (non-NWEC) }\end{array}$ & $\begin{array}{c}\text { Group B } \\
\text { (NWEC) }\end{array}$ & $\begin{array}{c}\text { Group C } \\
\text { (NWEC) }\end{array}$ & $\begin{array}{c}\text { Group D } \\
\text { (non-NWEC) }\end{array}$ \\
\hline 5 & 15 & 2 & 5 & 2 \\
\hline 4 & 1 & 3 & 2 & 1 \\
\hline 3 & 1 & 1 & 0 & 0 \\
\hline 2 & 3 & 2 & 0 & 1 \\
\hline 1 & 2 & 0 & 0 & 1 \\
\hline average score & 4.1 & 3.8 & 4.7 & 3.5 \\
\hline n= & 22 & 8 & 7 & 5 \\
\hline \hline
\end{tabular}

Overall, code officials believed jurisdictional support was very important to the successful implementation and enforcement of energy codes, and had the following to say on the subject: 
- "The energy code must have the council's support for success since they must allocate resources to it if needed."

- "Backing from the government adds credibility to the program and makes them assume responsibility for its success."

- "Jurisdictional support is important because [the local government] is the only body that builders have to go to."

- "The city council and the organized builder groups (ICBO) should be very involved and set up training programs that ensure the energy code's success."

- "If there is a problem we need to know we have the support and validity of the city."

A few jurisdictions did not believe jurisdictional support was very important. These jurisdictions typically had the following to say:

- "We get lots of new statutes, this is just another one. The city is concerned, but won't ultimately be involved."

- "The level of support from our jurisdiction really doesn't matter because we still have to enforce the code."

\section{I.2.4 Jurisdiction Networks}

Fifty percent of the code officials interviewed indicated that they were members of peer associations, including two who participated in countyorganized groups. (a) There was no significant difference in network participation across the four different jurisdiction groups. Table I.9 shows the distribution of network involvement.

The majority of code officials from jurisdictions involved in formal networks believed the process was effective in helping implement the WSEC; however, some believed it was only marginally effective or ineffective. Sixty-eight percent of code officials in formal networking arrangements said the process was effective; 11 percent said it was marginally effective; and 21 percent said it was ineffective.

(a) The categories of networks reported in the table are mutually exclusive. If a respondent indicated that he or she was a member of ICBO or another formal group, then that respondent was not counted as a participant in an informal network also. 
TABLE 1.9. Network Participation Reported by Jurisdictions

\begin{tabular}{||l|c|c|c|c||}
\hline \multirow{2}{*}{ Type of Network } & \multicolumn{2}{|c|}{$\begin{array}{c}\text { WSEC Program } \\
\text { Participants }\end{array}$} & \multicolumn{2}{c|}{$\begin{array}{c}\text { WSEC Program Non- } \\
\text { Participants }\end{array}$} \\
\cline { 2 - 5 } & $\begin{array}{c}\text { Group A } \\
\text { (non-NWEC) }\end{array}$ & $\begin{array}{c}\text { Group B } \\
\text { (NWEC) }\end{array}$ & $\begin{array}{c}\text { Group C } \\
\text { (NWEC) }\end{array}$ & $\begin{array}{c}\text { Group D } \\
\text { (non-NWEC) }\end{array}$ \\
\hline Formal (ICBO,AWC) & $52 \%$ & $55 \%$ & $43 \%$ & $60 \%$ \\
\hline Informal (local only) & $4 \%$ & $27 \%$ & $43 \%$ & $0 \%$ \\
\hline None & $44 \%$ & $18 \%$ & $14 \%$ & $40 \%$ \\
\hline \hline$n=$ & 23 & 11 & 7 & 5 \\
\hline
\end{tabular}

Code officials who stated that the process was effective generally credited the networks with bringing out consistent problems for group discussion. The following were examples of comments made by code officials who believed the formal process was effective in helping implement the new code:

- "The meetings are very helpful since we, as code officials, encounter similar problems with the energy code and the meeting allows for discussion of these problems."

- "The meetings are useful, but since there are so many differing opinions the process takes a lot of time."

- "The meetings promote county-wide consistency for the builders' sake."

Code officials from jurisdictions in formal networking arrangements, but who did not believe the process to be effective, complained of conflicting priorities of members, differing code interpretations, time burdens, and lack of leadership. Negative comments tended to come from the jurisdictions with the highest housing starts, often because there was not enough time to attend additional meetings. The following comments were typical:

- "Every jurisdiction had its own priorities and there is a tendency to trust your own interpretations."

- "Different jurisdictions interpret the code differently and place a different emphasis on code enforcement. We seem to be more energetic than other jurisdictions."

- "We need a stronger leader and the process is very time consuming."

All eight code officials who participated in informal networks stated that the process was effective, a significantly higher average rating than that reported by jurisdictions in formal networks. This was likely due to the fact that these informal network groups were typically self-selected and 
involved smaller groups of people, which reduced the incidence of opposing code interpretations, scheduling difficulties, time requirements, and travel.

Jurisdictions not involved in formal networking said that the process would be helpful, and two jurisdictions, in fact, were currently looking into their options.

\section{I.2.5 Building Activity Level}

In addition to the fact that activity level might affect code implementation success in different ways, how activity level would be measured was also problematic. Sudden increases in starts might be more detrimental than simply the number of starts. Some measure of the number of housing starts relative to enforcement resources would probably be a better indicator of how easily a jurisdiction could accommodate a new energy code. These types of data, however, were unavailable for our analysis. Consequently, we used building starts as our measure of activity level. If the data revealed significant relationships between starts and code implementation success, then that information could be used to target Program modifications.

Code officials' comments confirmed that no single, simple relationship existed between activity level and code implementation and enforcement. The following comments summarized the diverse role that code officials felt activity level played:

- "We can never do a full and complete inspection with high building activity levels."

- "The more activity, the better the probability of compliance due to more familiarity with the process by builders."

Two additional comments got directly at the heart of the issue - the relationship between activity level and resources to support code enforcement:

- "Over the past few years building in [our] county has skyrocketed with no/little increase in staffing to enforce codes. If the building activity weren't so great it would be much easier for us."

- "It shouldn't make a difference what the activity level is. If it is high and you have jurisdictional support there shouldn't be a problem, although builders may not have time to attend training if activity is very high and they may depend more on local jurisdictions to provide technical assistance."

Start-up support was one component of the Program that might have varied in importance depending on building activity level. Because jurisdictions overwhelmingly rated start-up support as very important, however, no correlation with activity level was likely.

To determine whether any relationship existed between building activity level and the need for training and assistance programs, we grouped the importance ratings given by code officials to these generic programs according 
to their activity level. There was a tendency for the high and very low activity level jurisdictions to rate the importance of training/assistance programs higher, but there was no clear correlation between activity level and the importance of such programs.

Overall, these results suggested that activity level, as measured by housing starts, had an indeterminate effect on code implementation. The results did suggest, however, that the training and assistance needs of the small and large jurisdictions should be examined more fully.

\section{I.3 PROGRAM IMPACTS ON CODE IMPLEMENTATION}

This section discusses our qualitative findings on the impacts, first on builder compliance, and then on code official WSEC implementation.

\section{I.3.1 Builder Compliance}

Code officials were asked questions about builders in their jurisdiction to identify any differences in reported builder compliance, problems, and attitude toward the code. Code officials were asked how builders in the ir jurisdiction had responded to the new code. We al so examined the effect of prior experience with the NWEC.

We grouped code official opinions about builder attitudes into three categories: "poor," "average," and "good." The following were examples of responses grouped into the "poor" category:

- "Builders hated the new code. There was a lot of resistance to the added paperwork needed to show compliance."

- "Builders responded just as they've responded to other changes - very negatively."

- $\quad$ "Builders responded with reluctance and hesitation, especially due to grey areas of the code such as ventilation."

The following were examples of responses categorized as "average":

- "Builders have responded fairly well. Luckily they have had some experience with [their local utility]."

- "Affirmative. There are problems with tightness but they are learning."

The following were examples of responses grouped into the "good" category:

- "Builders have responded very well, taking it all in stride."

- "Builders have been real receptive to the new code."

Table I.10 summarizes the results grouped by Program and NWEC participation. Overall, it appeared that builder response to the WSEC had 
been worse in jurisdictions participating in the Program than in those not participating. One possible reason, supported in part by the collected data, might be that Program jurisdictions were more knowledgeable about the code and more proactive in implementing and enforcing it.

Jurisdictions with prior NWEC experience reported better builder response to the WSEC than those without such experience. Information obtained during the interviews suggested that this might be due to the fact that builders in prior NWEC jurisdictions had experienced less change during the transition and were already building homes to a code (NWEC) that was very similar to the WSEC.

IABLE I.10. Code Official Reports of Builder Response to the New Code

\begin{tabular}{||l|c|c|c|c||}
\hline \multirow{2}{*}{ Score } & \multicolumn{2}{|c|}{ WSEC Program Participants } & \multicolumn{2}{|c|}{$\begin{array}{c}\text { WSEC Program Non- } \\
\text { Participants }\end{array}$} \\
\cline { 2 - 5 } & $\begin{array}{c}\text { Group A } \\
\text { (non-NWEC) }\end{array}$ & $\begin{array}{c}\text { Group B } \\
\text { (NWEC) }\end{array}$ & $\begin{array}{c}\text { Group C } \\
\text { (NWEC) }\end{array}$ & $\begin{array}{c}\text { Group D } \\
\text { (non-NWEC) }\end{array}$ \\
\hline \hline Good & $5 \%$ & $30 \%$ & $57 \%$ & $20 \%$ \\
\hline Average & $52 \%$ & $40 \%$ & $29 \%$ & $60 \%$ \\
\hline Poor & $43 \%$ & $30 \%$ & $14 \%$ & $20 \%$ \\
\hline \hline$n=$ & 21 & 10 & 7 & 5 \\
\hline
\end{tabular}

Table I.11 shows that, contrary to the apparent negative relationship between the Program and builder attitudes toward the WSEC (Table I.10), code officials in Program jurisdictions typically believed that the builders understood the WSEC slightly better than those in non-Program jurisdictions. A more significant difference was apparent when the effect of NWEC experience was investigated. Jurisdictions with prior NWEC experience reported significantly higher builder understanding of the WSEC than did non-NWEC jurisdictions. 
IABLE I.11. Code Official Reports of Builder Understanding of the New Code

\begin{tabular}{||l|c|c|c|c||}
\hline \multirow{2}{*}{ Score } & \multicolumn{2}{|c|}{ WSEC Program Participants } & \multicolumn{2}{|c|}{$\begin{array}{c}\text { WSEC Program Non- } \\
\text { Participants }\end{array}$} \\
\cline { 2 - 5 } & $\begin{array}{c}\text { Group A } \\
\text { (non-NWEC) }\end{array}$ & $\begin{array}{c}\text { Group B } \\
\text { (NWEC) }\end{array}$ & $\begin{array}{c}\text { Group C } \\
\text { (NWEC) }\end{array}$ & $\begin{array}{c}\text { Group D } \\
\text { (non-NWEC) }\end{array}$ \\
\hline Good & $20 \%$ & $70 \%$ & $57 \%$ & $20 \%$ \\
\hline Average & $45 \%$ & $20 \%$ & $29 \%$ & $40 \%$ \\
\hline Poor & $35 \%$ & $10 \%$ & $14 \%$ & $40 \%$ \\
\hline \hline$n=$ & 20 & 10 & 7 & 5 \\
\hline
\end{tabular}

There were few differences across jurisdiction groups in the types of compliance problems faced by jurisdictions in the field. The most commonly mentioned problems were related to insulation, caulking, vapor barriers, and proper installation techniques (14 total responses out of 34 jurisdictions reporting recurring problems). Problems related to exhaust fans and venting were also mentioned frequently (13 total responses). Other compliance problems included glazing area and U-values ( 5 responses), furnace sizing (1 response), and radon aspects of the code (1 response).

Code officials were asked to identify the root causes of noncompliance from the following list:

- Builders do not understand some aspect of code

- Builders are generally not willing to comply

- Builders are unable to get the supplies they need

- Subcontractors do not understand some aspect of the code

- Other

More than one of the above could be indicated by respondents. By far the most common response to this question was that builders did not understand some aspect of the code. A related response, subcontractors did not understand some aspect of the code, was also mentioned often. Table I.12 summarizes these responses. 
TABLE I.12. Reasons For Builder Recurring Noncompliance

\begin{tabular}{|c|c|c|c|c|}
\hline \multirow{2}{*}{ Key } & \multicolumn{2}{|c|}{ WSEC Program Participants } & \multicolumn{2}{|c|}{$\begin{array}{l}\text { WSEC Program Non- } \\
\text { Participants }\end{array}$} \\
\hline & ${ }_{\text {NWEC) }}^{\text {Group }} A$ (non- & $\begin{array}{c}\text { Group B } \\
\text { (NWEC) }\end{array}$ & $\begin{array}{c}\text { Group } C \\
\text { (NWEC) }\end{array}$ & $\begin{array}{c}\text { Group D } \\
\text { (non-NWEC) }\end{array}$ \\
\hline 1 & $93 \%$ & $67 \%$ & $67 \%$ & $100 \%$ \\
\hline 2 & $33 \%$ & $0 \%$ & $17 \%$ & $0 \%$ \\
\hline 3 & $33 \%$ & $0 \%$ & $17 \%$ & $0 \%$ \\
\hline 4 & $13 \%$ & $22 \%$ & $17 \%$ & $25 \%$ \\
\hline 5 & $20 \%$ & $11 \%$ & $17 \%$ & $25 \%$ \\
\hline $\mathrm{n}=$ & 15 & 9 & 6 & 4 \\
\hline \multicolumn{5}{|c|}{$\begin{array}{l}\text { Key } \\
\text { 1. } \\
\text { 2. Builders do not understand some aspect of code } \\
\text { 3. } \\
\text { 4uilders are generally not willing to comply } \\
\text { 5. Subcontractors to get the supplies they need } \\
\text { Note: Percentages are based on those respondents reporting recurring } \\
\text { compliance problems. }\end{array}$} \\
\hline
\end{tabular}

Jurisdictions with NWEC experience appeared to have fewer compliance problems linked to builder understanding of the WSEC.

Six respondents (18\%) stated that builders were generally not willing to comply. Four of these respondents also stated that builders were not able to get the supplies they needed. However, some also stated that certain builders used lack of available supplies as an excuse for noncompliance, and that the majority of other builders in the area had no supply problem. Most of those who responded that "builders are unable to get the supplies they need" added that this was a temporary problem during transition and the initial code implementation period. Several respondents stated that there should have been more up-front support by the state to inform suppliers of code requirements and the upcoming product needs prior to code implementation.

According to some respondents, framers, insulation installers, electricians and mechanical subcontractors didn't get adequate information on the code; therefore, their skill level was lacking and they had trouble getting a building to comply. The high turnover rate of these subcontractors contributed to the problem.

Other reasons for building noncompliance included the extremely technical nature of the code, builders rushing to get things done, and 
problems associated with remodeling a house (e.g., plan review difficulties and the fact that inexperienced homeowners attempted to do the work).

In general, there did not appear to be a current supply problem for products that complied with the WSEC. Only five respondents, all from areas without NWEC experience, stated that compliance problems were related at least in part to builders' inability to get the supplies they needed. Not surprisingly, it appeared that supplies emerged as a problem initially in jurisdictions where suppliers did not have to carry specific products in the past. Some code officials attributed part of the problem to builder efforts to reduce costs by trying to substitute noncomplying items for more expensive, complying ones.

\section{I.3.2 Program Impacts on Code Official Implementation of the WSEC}

Code officials were asked to score the importance of generic training and technical assistance programs on a scale from 1 (unimportant) to 5 (very important). The scores were distributed as shown in Table C.13.

TABLE I.13. Code Officials' Assessment of Importance of Generic Training and Assistance Programs

\begin{tabular}{||l|c|c|c|c||}
\hline \multirow{2}{*}{ Score } & \multicolumn{2}{|c|}{ WSEC Program Participants } & \multicolumn{2}{|c|}{$\begin{array}{c}\text { WSEC Program Non- } \\
\text { Participants }\end{array}$} \\
\cline { 2 - 5 } & $\begin{array}{c}\text { Group A } \\
\text { (non-NWEC) }\end{array}$ & $\begin{array}{c}\text { Group B } \\
\text { (NWEC) }\end{array}$ & $\begin{array}{c}\text { Group C } \\
\text { (NWEC) }\end{array}$ & $\begin{array}{c}\text { Group D } \\
\text { (non-NWEC) }\end{array}$ \\
\hline 5 & $67 \%$ & $44 \%$ & $57 \%$ & $100 \%$ \\
\hline 4 & $10 \%$ & $33 \%$ & $29 \%$ & $0 \%$ \\
\hline 3 & $19 \%$ & $22 \%$ & $14 \%$ & $0 \%$ \\
\hline 2 & $5 \%$ & $0 \%$ & $0 \%$ & $0 \%$ \\
\hline 1 & $0 \%$ & $0 \%$ & $0 \%$ & $0 \%$ \\
\hline average score & 4.4 & 4.2 & 4.4 & 5.0 \\
\hline \hline n= & 21 & 9 & 7 & 5 \\
\hline \hline Note: $5=$ very important, $1=$ unimportant & & \\
\hline
\end{tabular}

Controlling for participation in the NWEC, code officials tended to consider the training and assistance programs for energy code implementation slightly less important if they had participated in the WSEC Program. NWEC participation appeared to have a similar effect on code officials' assessment of the importance of such programs: if the code official had participated in the NWEC he or she viewed such programs as slightly less important. This finding suggested that programs may not live up to expectations that they would be able to solve many of the potential problems encountered with a new 
code. These data did not suggest that there was a large frustration with programs not meeting expectations, but should provide a caution to program designers and implementers that there might be differences between expectations and what a program can actually deliver.

To obtain a direct assessment of the benefits of the WSEC Program specifically, we asked code officials from jurisdictions in the WSEC Program to rate the influence of the WSEC Program on code implementation success. (a) These results are shown in Table C.14. Similar to the results for the rating of such programs generically (Table I.13), the non-NWEC jurisdictions tended to rate the effectiveness of the WSEC Program higher than did the NWEC jurisdictions; i.e., jurisdictions that were not in the NWEC felt that the WSEC Program had more of a positive effect on implementation of the WSEC than those jurisdictions that were in the NWEC.

TABLE I.14. Code Officials' Assessment of Benefits of WSEC Program

\begin{tabular}{||l|c|c|}
\hline \multirow{2}{*}{$\begin{array}{l}\text { Magnitude of WSEC } \\
\text { Program Benefits }\end{array}$} & \multicolumn{2}{|c|}{ WSEC Program Participants } \\
\cline { 2 - 3 } & Group A (non-NWEC) & Group B (NWEC) \\
\hline \hline Large & $75 \%$ & $50 \%$ \\
\hline Some & $20 \%$ & $38 \%$ \\
\hline Smal1 & $5 \%$ & $13 \%$ \\
\hline \hline$n=$ & 21 & 11 \\
\hline
\end{tabular}

Code officials from WSEC Program jurisdictions were asked if they believed that they and other code officials at their agency had received sufficient training and support through the WSEC Program to enforce the new code, or if they believed some additional training or other support should be provided. Table I.15 provides the results.

TABLE I.15. Code Official Reports of Sufficiency of Training and Support: Program Participants

\begin{tabular}{||l|c|c||}
\hline Response & $\begin{array}{c}\text { Group } A \\
\text { (non-NWEC) }\end{array}$ & $\begin{array}{c}\text { Group } B \\
\text { (NWEC) }\end{array}$ \\
\hline \hline Yes, received sufficient training & $76 \%$ & $91 \%$ \\
\hline No, did not receive sufficient training & $24 \%$ & $9 \%$ \\
\hline \hline$n=$ & 21 & 11 \\
\hline
\end{tabular}

(a) Because non-Program jurisdictions had no firsthand experience with the Program, we did not ask them to rate the importance of the Program. 
While the majority of respondents stated that their office had received sufficient training, most were quick to add that there was a need for on-going training. The following are some of the responses from code officials who believed that they were adequately prepared to enforce the code:

- "The training and support has been adequate and effective, but I think we need more. The training makes a lot more sense after some actual experience in the field."

- "Yes, we have received adequate training and support. I would hate to see the training stopped since continuing education is the only way to create skilled people."

Overall, 19\% of the Program jurisdictions suggested that the Program training had not adequately prepared them to enforce the code. Comments suggested that the reasons ranged from the complexity of the code to inadequacies in the assistance provided:

- "I don't see how we can ever get a clear picture of the code, it is just too complicated."

- $\quad$ "There should be a more flexible training schedule, such as evening hours, so that jurisdictions like ours with time constraints could attend. The classes are usually during work hours, and we are too busy to attend."

- "The assistance we've received has been too general and not helpful in getting us up to speed on the new code."

Table I.15 also shows that a substantially larger share of former NWEC participants believed that the Program training had been sufficient than nonNWEC jurisdictions. It was likely that this higher adequacy rating was due to the fact that NWEC participants were well prepared to implement the WSEC as a result of their NWEC training.

We also asked jurisdiction participants if there was anything additional that could better prepare them for code enforcement. Responses to this question revealed in part whether the code officials felt adequately prepared, through their participation in the Program, to implement the code. Results are summarized in Table I.16. 
IABLE I.16. Code Official Beliefs that Something Additional Could Be Done to Prepare Them for WSEC Enforcement: Program Participants

\begin{tabular}{||l|c|c|}
\hline $\begin{array}{l}\text { Could something additional be done to } \\
\text { prepare you for code enforcement? }\end{array}$ & $\begin{array}{c}\text { Group A } \\
\text { (non-NWEC) }\end{array}$ & $\begin{array}{c}\text { Group B } \\
\text { (NWEC) }\end{array}$ \\
\hline No, no more needs to be done & $19 \%$ & $60 \%$ \\
\hline Yes, more needs to be done & $81 \%$ & $40 \%$ \\
\hline \hline$n=$ & 21 & 10 \\
\hline
\end{tabular}

These results were very different from the results reported in the previous table. These results indicated that two-thirds of all Program participants felt that they were inadequately prepared to enforce the WSEC. These results suggested that changes other than improvements in the training were felt to be necessary. Code official responses indicated that such changes included code revisions, administrative support (staffing), and some training enhancements.

NWEC experience appeared to have had a positive effect on experiences with the WSEC. Eighty-one percent of the non-NWEC jurisdictions felt that there were additional things that could be done to prepare them for code enforcement. Among jurisdictions with NWEC experience, the percentage who thought more could be done was only about half that amount.

We also examined code official attitudes toward the WSEC to assess WSEC Program effects. We identified key words that expressed attitudes and searched through all the interview responses to locate these words. The occurrences were then grouped into categories associated with attitudes toward different aspects of the code.

Neither the Program nor past experience with the NWEC appeared to have a significant effect on code officials' receptivity to the WSEC and their assessment of the code's complexity. Code officials in jurisdictions that both had and had not participated in the WSEC Program expressed similar receptivity to the code. About $10 \%$ of each group expressed reservations about the acceptability of the code, based on its complexity and difficulties of understanding it. Typical comments from respondents in this category included the following:

- "WSEC is the worst code to have to enforce, and it's particularly difficult because the building industry hasn't accepted it yet."

- "We can never get a clear picture of the code, it's just too complicated."

On the other hand, about $10 \%$ of code officials in both Program and non-Program jurisdictions appeared to be quite receptive to the code: 
- "The code is very flexible and problems are easy to resolve."

- "[Builders] mainly [use the] prescriptive path, so it goes pretty easy."

Code officials did have other important concerns about the code. Several mentioned 1) their ability to explain and justify the requirements of the code to builders, 2) the frequency of changes to the energy code, and 3) the shift of resources necessitated by the WSEC code away from safety issues as problems. These concerns were more pronounced in the jurisdictions not participating in the Program. For example, 25\% of non-participants expressed concerns about the code being hard to justify or changing too often. Prior NWEC participants expressed some difficulties about changing from the NWEC to the WSEC. Typical comments included the following:

- $\quad$ "The energy code seems to place too much importance on conservation, and it is surely important, but they seem to forget about safety issues."

- "It would help [to understand] why things are being done the way they are. For example 'Why do we tighten up the house and then put holes in the wall?' I don't completely understand this myself so it is hard to justify."

One attitude was very different between WSEC Program participants and non-participants: a perception of burdens caused by the code. Half the Program non-participants felt that the code was burdensome, either because they felt their jurisdiction was too small to implement the code successfully or it was inequitable to put so much of the burden on the jurisdiction. None of the Program participants voiced similar concerns in their interview comments. Code officials with these concerns made comments such as these:

- We are a small jurisdiction and tried to negotiate with the state to have these paperwork requirements reduced, but they wouldn't compromise for us."

- "We wish somewhere down the line the WSEC would make more considerations for small jurisdictions."

Five of the six Program non-participants with such concerns were former NWEC jurisdictions.

The Program's ability to ease code implementation appeared to be questioned by several smaller jurisdictions and they had chosen to not participate. Their major concern was a general lack of staff and other resources. Most viewed joining the Program as undesirable because it would only increase the demands on their staff and, because most of the benefits (training and technical assistance) were already available, the added paperwork to join the Program was not worth any additional benefits of formal participation. Many drew this conclusion based on bad experiences with the NWEC:

- "[The Program] paperwork would make it tough on us. We were glad to get rid of reports required as part of NWEC program." 
- $\quad$ "My experience with the NWEC program has made me leery. Before I came to [this jurisdiction] my jurisdiction was signed up for the NWEC program. We had problems dealing with BPA and the paperwork requirements."

Jurisdictions with high building activity levels tended to feel that the WSEC was too complex or hard to understand and enforce. No similar pattern was clear for jurisdictions with lower activity levels. High building activity jurisdictions also tended to express negative attitudes about the ease of justifying and explaining the WSEC and the fact that it shifted resources from other important considerations such as safety.

\section{I.4 OTHER RESPONDENT COMMENTS AND RECOMMENDATIONS}

During our interviews, we asked the code officials to identify additional important issues that were not already covered, recommendations they would like to make about the Program or WSEC, and what they would like to see from the evaluation. The pattern of responses was consistent across all jurisdiction groups. This section summarizes those responses.

\section{I.4.1 Other Important Issues}

There were a few issues that code officials brought up that did not fit neatly into the categories defined for the evaluation. The following comments summarize such issues:

- $\quad$ "The fact that the code does not address some basic equity issues surrounding the people it affects causes me great concern."

- $\quad$ "There should be some attention paid to the financial impact of increasingly strict energy code enforcement on jurisdictions ... It appears that the politicians just pass it off to the jurisdictions and forget it ... Since the jurisdiction's general funds are usually in the red, there is a negative cash flow to the building department and customers don't get the level of service they are paying for."

"There needs to be more verification of the impact and compliance of the code. I called the radon hotline ... I found that only 5 test kits had been turned in from our county - about 500 homes had been qualified! Something is wrong here. I would like to see test statistics on how the code is working."

- "Are there moisture problems? Are people using their ventilation systems correctly? What are the environmental and health impacts of the new code? These are important questions."

- "The current code ... needs to address remodels." 


\subsubsection{Code Official Recommendations}

Many code officials recommended that the WSEC not be changed without adequate time and review. Several recommended that changes occur on a regularly scheduled cycle.

"The code shouldn't be changed without knowledge or time. We need time to get the products on line, dissemination of information. We need to slow the system down, to enable the suppliers to get the supplies available."

- "I like code changes every 3 years rather than yearly. This would coincide with UBC and Uniform Residential Code change cycle."

- "Builders have some concerns: 'How often will we be faced with changing codes?' This is a major issue to builders who have a hard time dealing with this. It is hard to get their support when we keep changing things."

Many officials recommended code simplification:

- $\quad$ "They need to keep the code simple and easier to enforce. They're not working with engineers, they're working with the public, so they need to be simplified."

- "The code itself needs more of a prescriptive route. This could speed things up."

Some code officials had specific recommendations about how to ease implementation:

- $\quad$ "Thorough training and understanding should be done before implementation."

- "Somehow the subcontractors need to be trained since they are the ones who do the work in the field; the program seems to reach the general contractors OK but they don't pass the information along."

- $\quad$ "There needs to be more attention paid to public awareness and education. The demand should come from the home buyer in order to make this program a true success. People need to be aware of the benefits of an energy efficient home."

- $\quad$ "It would be helpful if there was some kind of regulation when dealing with subcontractors who chronically have problems. They should either be required to go through training or get certified."

- "WSEO should provide a list of contractors that have taken the training to all jurisdictions. Incentive-type programs to get contractors involved might be good." 
- "The training should be offered to us when we can come; it should be in smaller class sizes and the builders/suppliers should come to the same sessions. This would allow the builders to see where some of the requirements come from."

- "I would like to see education programs changed from time to time so that there would be new materials to learn. Newsletters would be good."

- It might be a good idea for more code officials to take the 'energy specialist' exam offered by WABO (I think they are ones who offer it)."

- $\quad$ "Program should emphasize training to subcontractors such as mechanical installers so that they understand the code too."

"I specifically recommend: 1) Remove interpretation of energy code questions from ICBO. Fund a WSEO person $8 \mathrm{hrs}$ a day to answer all questions; 2) Revise training programs to include 1 or 2 day seminars in addition to one on one types as requested by jurisdictions; 3 ) Provide a computer software program to track information required by WSEO."

\section{I.4.3 Use of the Evaluation}

The code officials almost universally expressed an interest in seeing the results of the evaluation. Many expressed a keen interest in how other jurisdictions were doing, the problems they faced, and how they were resolving them.

Many officials wanted to make sure that the evaluation results were used to improve the Program and the WSEC. Comments such as the following were typical:

- II would like to see that the appropriate government bodies and other organizations learn what makes an energy code and program work; this includes the building departments, state government, and everyone."

- II would like to know that someone has seen our comments about social equity issues."

- I'd like to get an interpretations book."

- $\quad$ "A lot of people should be recognized for their hard-working efforts and commended." 


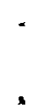


DISTRIBUTION

No. of

Copies

\section{OFFSITE}

12 DOE/Office of Scientific and Technical Communication

ONSITE

Pacific Northwest Laboratory

F. E. Barwig

J. W. Carrie

D. R. Conover

D. L. Durfee

T. L. Gilbride

J. A. Johnson

A. D. Lee (20)

B. L. Mohler

E. E. Richman

L. J. Sandahl

W. M. Warwick (10)

Publishing Coordination

Technical Report Files 


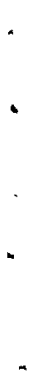





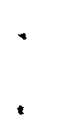

